QL
362 W
C59
1922
INVERT.
ZOOL.

Hr. 



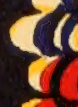

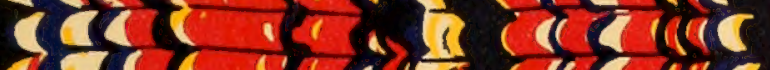

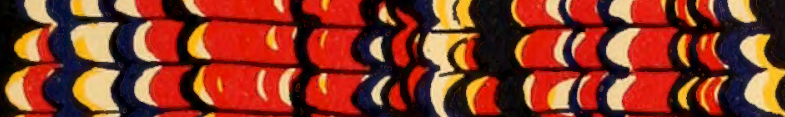
$\rightarrow a\left\{\begin{array}{l}1 \\ 4\end{array}\right.$ ce 2 सा

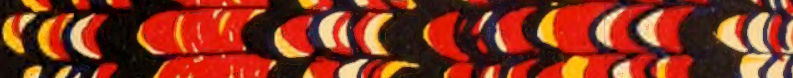

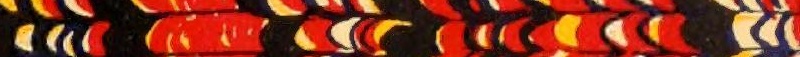

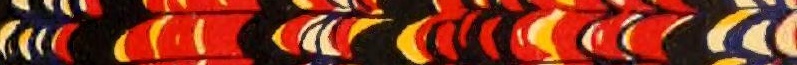

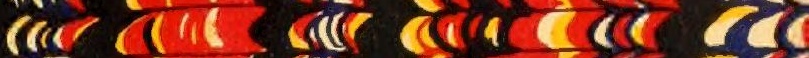

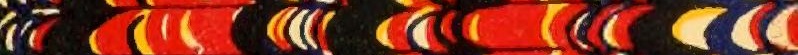
$\cos s)-11$
arae culecro

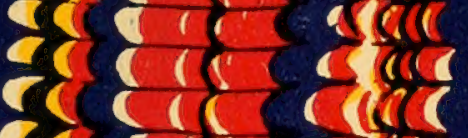
are 40
a 12
a $4 \cos$
a
48

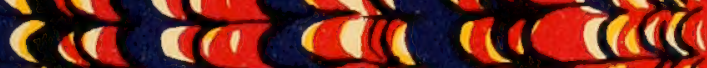

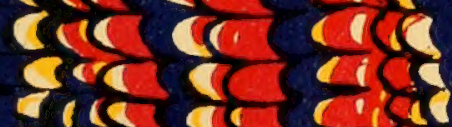

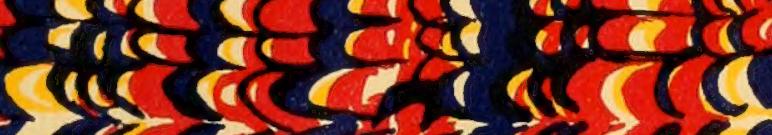

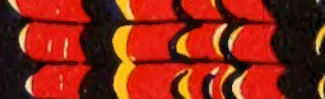

r(ce

बier cura cor

(C) 1
1 c)

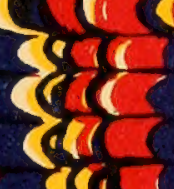

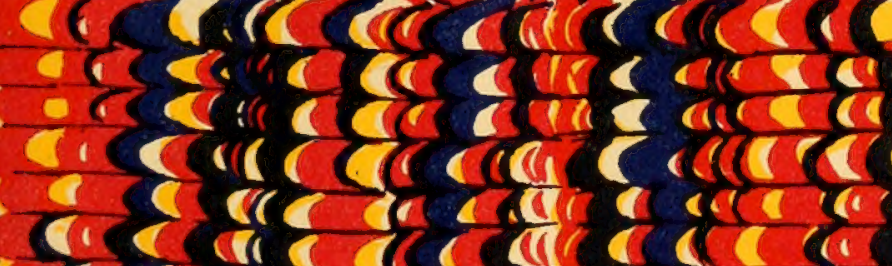

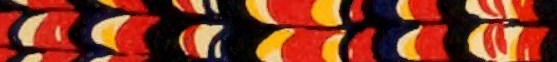

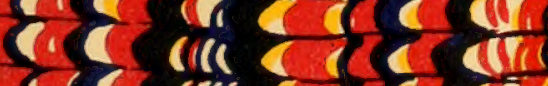

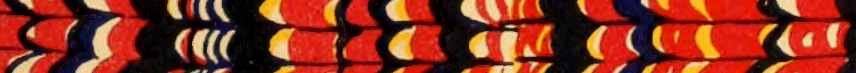

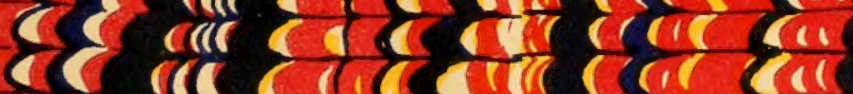

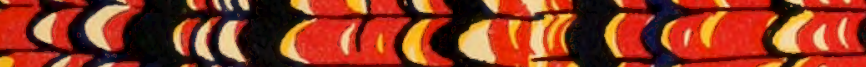

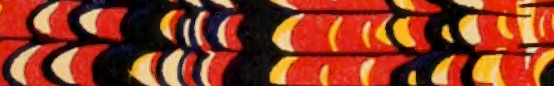

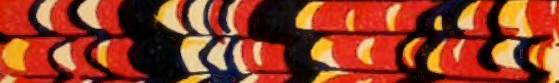

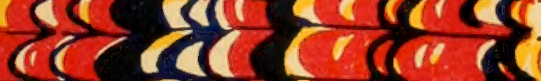
cal यa ar a $\rightarrow \operatorname{licha}$

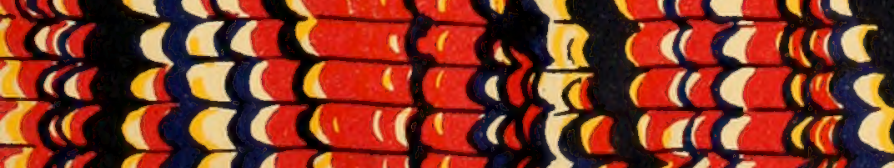

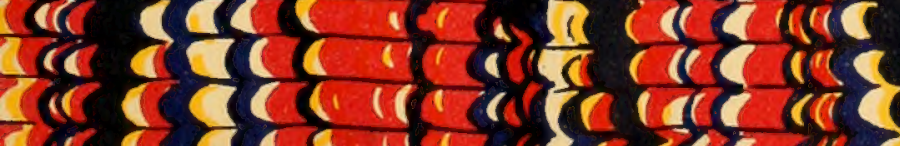
ire cis ica (1) c do 10 
, 


DEPARTMENT OF THE INTERIOR

ALBERT B. FALL, Secretary

UNITED STATES GEOLOGICAL SURVEY

George OTIS SMITH, Director

Professional Paper 124

\section{THE INORGANIG CONSTITUENTS OF MARINE INVERTEBRATES}

SECOND EDITION, REVISED AND ENLARGED

BY

FRANK WIGGLESWORTH CLARKE

AND

WALTER CALHOUN WHEELER
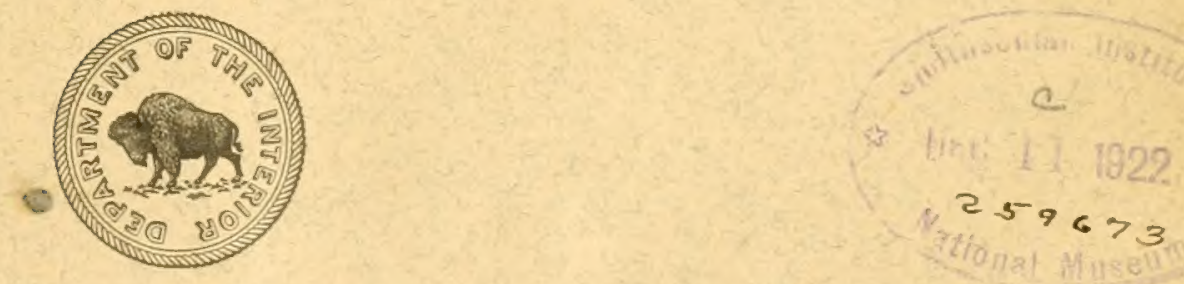

WASHINGTON

GOVERNMENT PRINTING OFFICE 

UNITED STATES GEOLOGICAL SURVEY

GEORGE OTIS SMTh, Director

Professional Paper 124

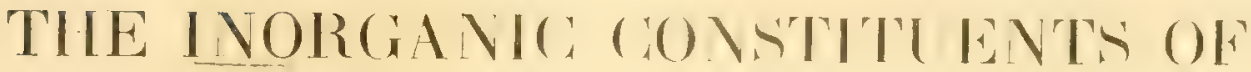 MARINE INTERTEBRATES
}

\author{
SECOND EDITION, REVISED AND ENLARGED
}

13)

\author{
FRANK WIGGLESWORTII CLARKE \\ AND
}

WALTER CALHOUN WHEELER

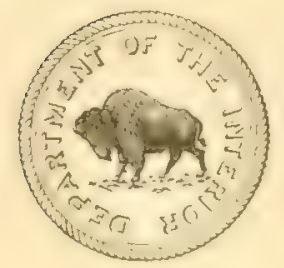

WASHTNGTON

GOVEIRMENT PRINTIXG OFFICE 


\section{CONTENTS.}

Introduction

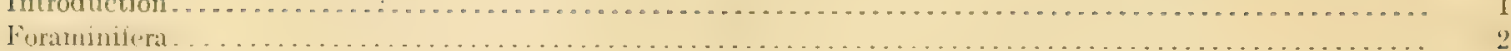

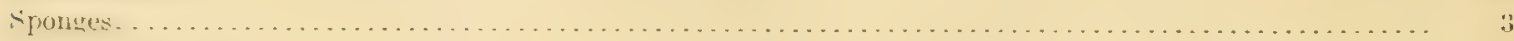

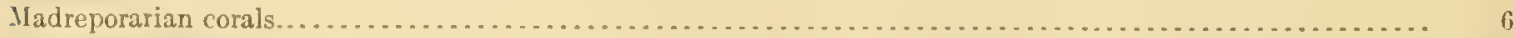

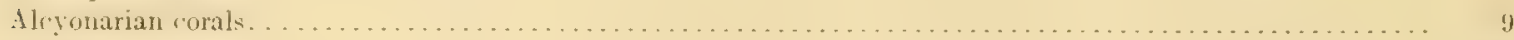

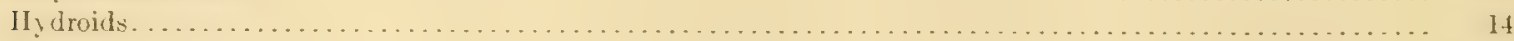

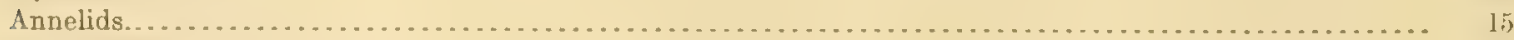

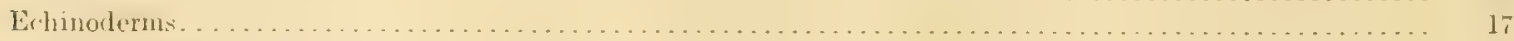

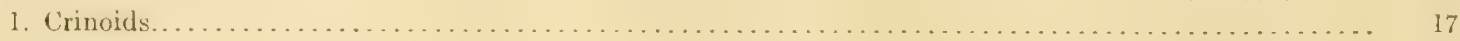

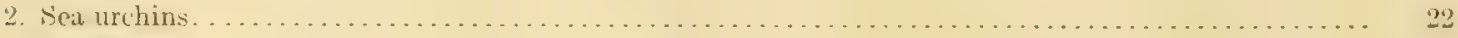

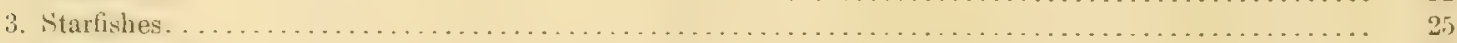

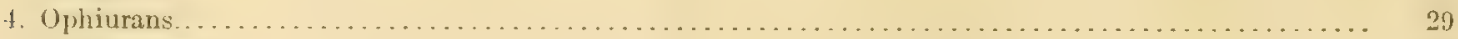

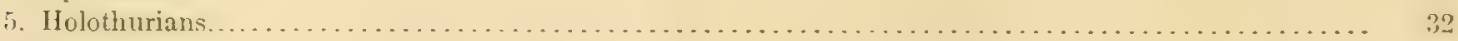

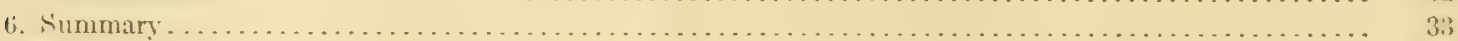

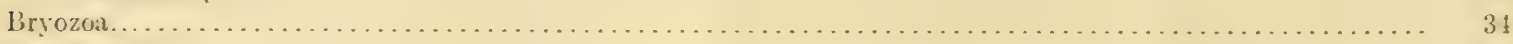

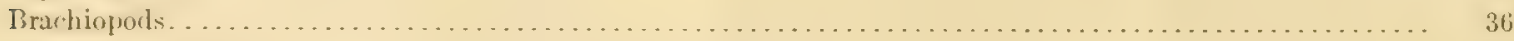

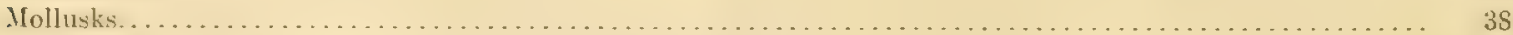

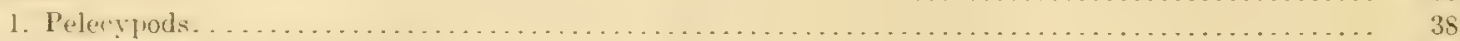

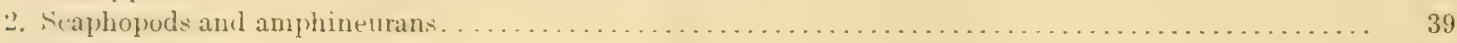

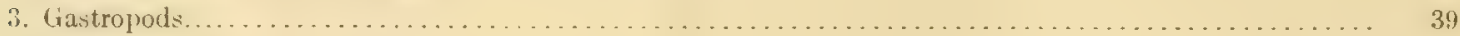

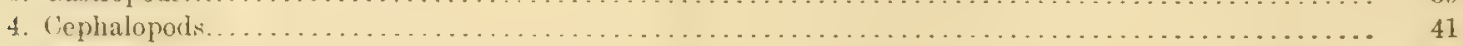

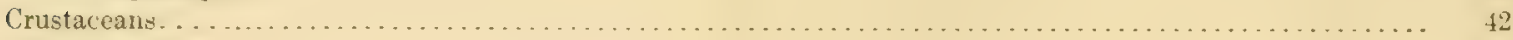

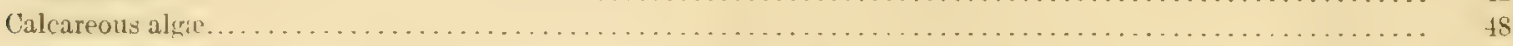

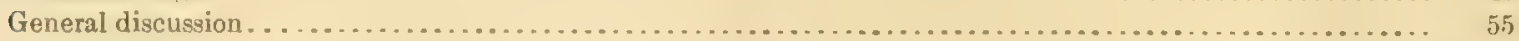




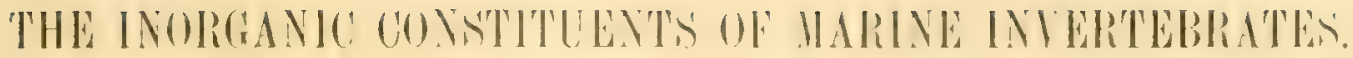

\author{
By Frank Wigglesworti Cuarke and Walter Califoun Wiefeler.
}

\section{INTROIDUC'IION.}

That many rocks were once marine sediments and that animals and plants shared in their formation is one of the commonplaces of geology. Coralline limestones; shell limestones, and crinoidal limestones are among the most familiar illustrations of this statement. That corals and shells furnish calcium carbonate to the sediments, that radiolarians and diatoms are silienous, and that vertebrate animals, some crustaceans, and a few brachiopods are more or less phosphatic are also well-known facts, which, however, have been determined in a more or less desultory way. No systematic investigation to ascertain just what substances each class of organisms contributes to the sediments seems to have been made, and the present research is an attempt to cover the ground a little more thoroughly than it has been covered heretofore. Completeness is, of course, impossible, but something of a foundation for future work we have tried to lay.

Although many analyses of corals and molluscan shells are on record, some important groups of organisms have received only slight attention, and little has been done heretofore toward determining the composition of their tests or skeletons. 'The few published dat $\Omega$, moreover, have been generally but not always incomplete in certain particulars, especially with regard to the localities from which the specimens analyzed were obtained, the depth of water in which each creature lived, and the temperature of its habitat. Even in our own work some of these details are lacking, but their great significance when known is strikingly evident in the study of such groups of animals as the echinoderms and alcyonarians. Furthermore, some of the older analyses are unsatisfactory for other reasons, for many of them were made to determine single facts, such, for instance, as the proportion of magnesium carbonate alone; and in others such essential constituents as organic matter were not taken into account, an omission that is especially serious, for it renders the accurate comparison of the analyses with others impossible. In the shells of mollusks the proportion of organic matter is small, but in the echinoderms, alcyonarians, and phosphatic brachiopods it is relatively large, ranging from 10 to even 40 per cent or more. This statement, however, must not be misconstrued; it refers, of course, only to the specimens, dried or alcoholic, which were actually analyzed. In order to compare the analyses, therefore, so as to determine the true composition of the inorganic shells or skeletons, the very variable amounts of organic matter must be rejected, and the remainders recalculated to 100 per cent. Relations then appear which are not recognizable when the crude unreduced analyses are compared. Any one of our tables of analyses will show this fact rery clearly.

In a strict sense completeness can not be claimed eren for our analyses. Minor constituents which have been detected in marine organisms, such as barium, strontium, fluorine, manganese, copper, zinc, and lead, have been ignored. They occur, as a general rule, only in traces and have little or no significance with respect to the larger problems before us. What organisms tend to form limestones and what ones are notably magnesian, phosphatic, or siliceous are the questions which we are attempting to answer. In most of the analyses lime, magnesia, phosphoric oxide, sulphur trioxide, silica, and loss on ignition were determined. Alumina and oxide of iron were also considered and weighed together. The loss on ignition covered carbon dioxide, 
organic matter, and water. The carbon dioxide was calculated to satisfy the bases, and the amount thus determined, subtracted from the total loss on ignition, gave a fair but rough estimate of organic matter plus water. From the crude analyses thus obtained the reduced or rational analyses, recalculated to 100 per cent, were computed. These rational analyses are comparable, and gire, closely enough, the essential composition of the material which goes to build up the limestones. Inore refined work would add little toward the solution of our main problem and would require much tedious labor. In the following pages the detailed analyses are giren, group by group, together with some of the older published data. After the evidence has been presented a general discussion of its significance will be in order.

In the former edition of this paper (published in 1917 as Professional Paper 102) the analyses, with few exceptions, were made by the junior author. In this edition we are able to present a large number of new analyses, made in order to strengthen weak series or to clear up some outstanding uncertainties. These analyses, which were made by Messrs. A. A. Chambers, R. M. Kamm, B. Salkover, and George Steiger, are credited to the respective analysts. All other's were made by Wheeler.

\section{FORAMINIFERA.}

The Foraminifera, because of their enormous abundance, are of great importance in the formation of marine sediments. The globigerina ooze, for example, covers $49,520,000$ square miles of the ocean floor, at a depth of 1,996 fathoms, or 3,653 meters. The analyses of it published in the report of the Challenger expedition on deep-sea deposits show that it consists mainly of calcium carbonate, with very little magnesia. Foraminifera are also abundant on "coral reefs," and great masses of limestone are composed largely of their remains.

These organisms, however, are so small, rarely larger than the head of a pin, that it is not easy to obtain enough material of any one species for chemical analysis. The difficulty, fortunately, is not insuperable, and with the help of others we were able to obtain representative samples of soven species, as follows:

1. Pulvinulina menardii D'Orbigny. Albatross station 2573; latitude, $40^{\circ} 34^{\prime} 18^{\prime \prime} \mathrm{N}$.; longitude, $66^{\circ} 09^{\prime} \mathrm{W}$.; in line from Long Island Sound to Cape Sable; depth of water, 3,188 meters; bottom temperature, $3^{\circ} \mathrm{C}$.

2. Spharodina dehiscens Parker and Jones. East coast of Mindanao, Philippine Islands; Iatitude, $8^{\circ} 5 I^{\prime} 45^{\prime \prime} \mathrm{N}$., longitude, $126^{\circ} 26^{\prime} 52^{\prime \prime}$ E.; depth of water, 804 meters.

3. Tinoporus baculatus Carpenter. Murray Islands, Torres Strait, Australia.

4. Orbitolites marginatis Lamarck. South of Tortugas, Fla., at depth of 29.3 meters.

5. Orbiculina aduncr Fichtel and Moll. Key West, Fla.

6. Polytrema mineaccum Linné. Bahamas.

7. Quinqueloculina auberiana D'Orbigny. Same locality as No. 4; analysis by A. A. Chambers. Analyses of Foraminifera.

\begin{tabular}{|c|c|c|c|c|c|c|c|}
\hline . & 1 & 2 & 3 & 4 & 5 & 6 & 7 \\
\hline 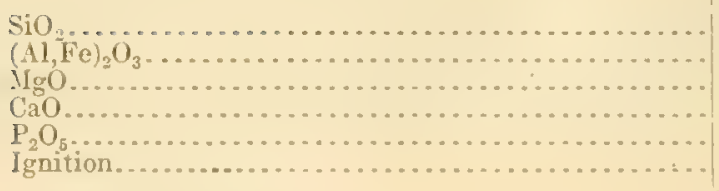 & $\begin{array}{r}14.70 \\
3.81 \\
1.68 \\
41.36 \\
(?) \\
38.12\end{array}$ & $\begin{array}{r}8.55 \\
4.76 \\
.82 \\
45.48 \\
(?) \\
39.01\end{array}$ & $\begin{array}{r}0.03 \\
.18 \\
5.03 \\
47.35 \\
.00 \\
46.57\end{array}$ & $\begin{array}{l}0.03 \\
.13 \\
4.93 \\
48.92 \\
\text { Trace. } \\
45.20\end{array}$ & $\begin{array}{r}0.11 \\
.09 \\
4.64 \\
48.79 \\
\text { Trace. } \\
45.56\end{array}$ & $\begin{array}{l}0.02 \\
5.09 \\
47.35 \\
(?) \\
46.24\end{array}$ & $\begin{array}{l}0.51 \\
4.32 \\
49.02 \\
(?) \\
45.54\end{array}$ \\
\hline 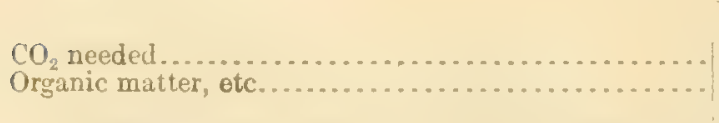 & $\begin{array}{r}99.67 \\
34.41 \\
3.71\end{array}$ & $\begin{array}{r}98.62 \\
36.63 \\
2.35\end{array}$ & $\begin{array}{r}99.16 \\
42.74 \\
3.73\end{array}$ & $\begin{array}{r}99.48 \\
43.90 \\
1.30\end{array}$ & $\begin{array}{r}99.19 \\
43.43 \\
2.13\end{array}$ & $\begin{array}{r}98.70 \\
42.80 \\
3.44\end{array}$ & $\begin{array}{r}99.42 \\
43.27 \\
2.27\end{array}$ \\
\hline
\end{tabular}

Rejecting organic matter and water ("ignition") and recalculating to 100 per cent, the analyses assume the following rational form: 
Reduced analyses of foraminifera.

\begin{tabular}{|c|c|c|c|c|c|c|c|}
\hline & 1 & 2 & 3 & 4 & 5 & 6 & 7 \\
\hline \multirow[t]{2}{*}{ 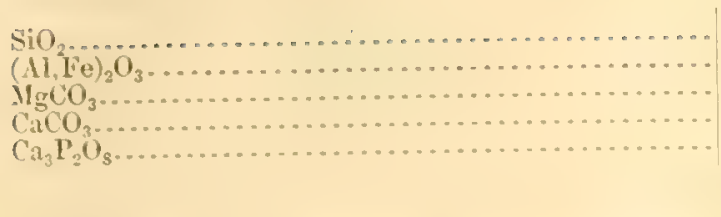 } & $\begin{array}{r}15.33 \\
3.93 \\
3.67 \\
77.02 \\
(?) \\
\end{array}$ & $\begin{array}{r}\text { 8. } 59 \\
\text { 4. } 94 \\
1.79 \\
\text { S4. } 39 \\
(?) \\
\end{array}$ & $\begin{array}{r}0.03 \\
.19 \\
11.05 \\
88.70 \\
.00\end{array}$ & \begin{tabular}{r|}
0.31 \\
.13 \\
10.55 \\
S9.01 \\
Trace.
\end{tabular} & $\begin{array}{l}0.11 \\
.09 \\
10.04 \\
89.76 \\
\text { Trace. }\end{array}$ & $\begin{array}{c}0.02 \\
11.22 \\
58.76 \\
(?)\end{array}$ & $\begin{array}{l}0.56 \\
9.33 \\
90.11 \\
(?)\end{array}$ \\
\hline & $\overline{100.00}$ & 100.00 & 100.00 & 100.00 & 100.00 & 100.00 & 100.00 \\
\hline
\end{tabular}

In Nos. 1 and 2 the high percentages of siliea and sesquioxides are evidently due to impurities. If they are rejected, the percentages of magnesium carbonate become 5.19 and 2.09, respectively. These two Foraminifera are from don and presumably cold watr. The ofhers are from shallow water in warm regions. A similar difference in the manesian content of the organisms with regard to temperature appears, with much regularity, in sereral other series of our analyses, notably in the series of crinoids and alcyonarians.

The only published analyses of Forminifera that we have been able to find elsewhere

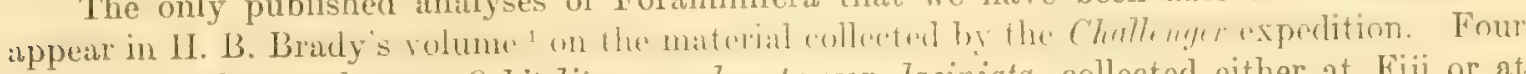
of these analyses relate to Orbitolites complanata var. laciniata, collected either at Fiji or at 'Tongatabu, Friendly Islands. These analyses are as follows:

1, 2. Two different samples; analyses by C. R. A. Wright and J. T. Dunn.

3. Sample washed with boiling water.

4. Same as No. 3, unwaslied; analyses 3 and 4 by J. Gibson.

Analyses of orbitolites.

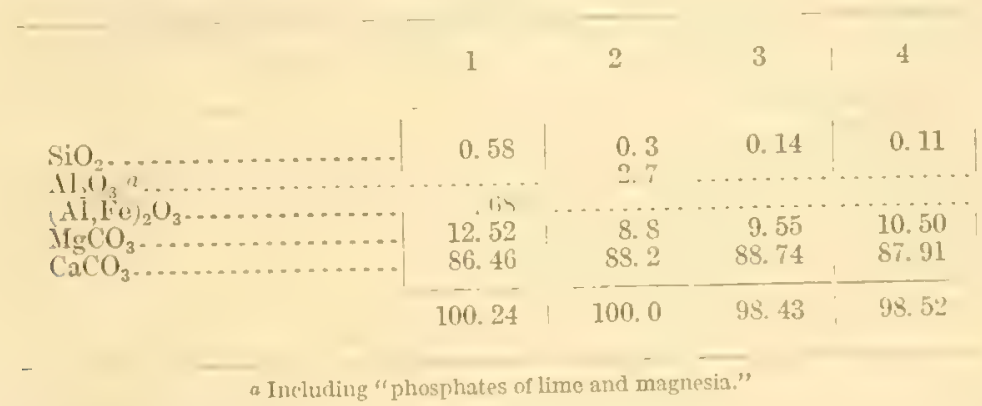

Other analyses, presented by Wright and Dunn, are of Amphistegina lessunii, from Cape

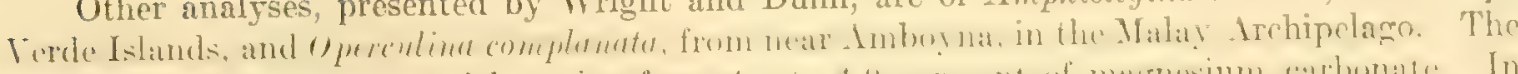

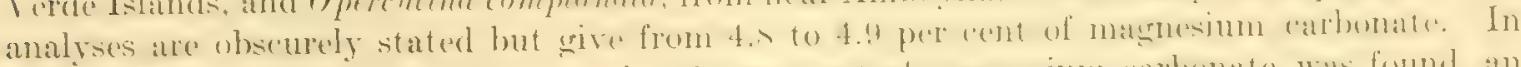

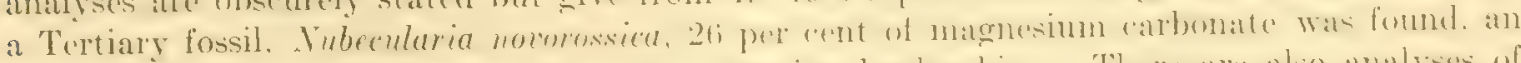

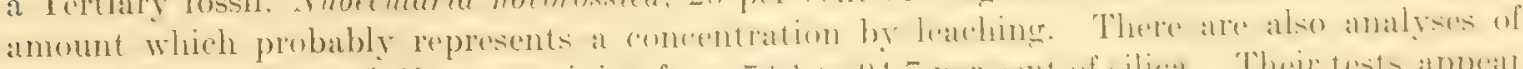

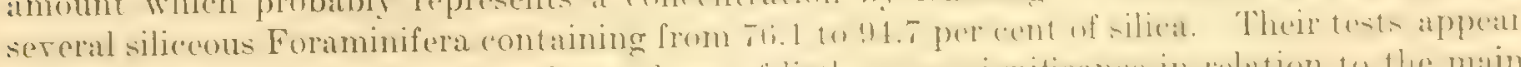

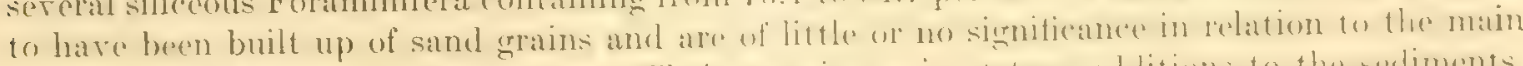
problem of the present investigation. Their remains are mot true alditions to the sediments.

\section{SIONGES.}

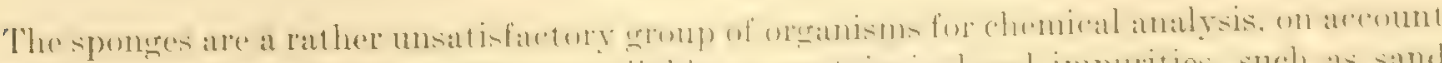

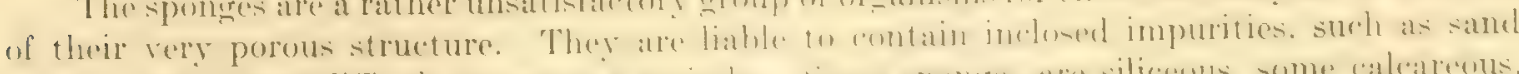

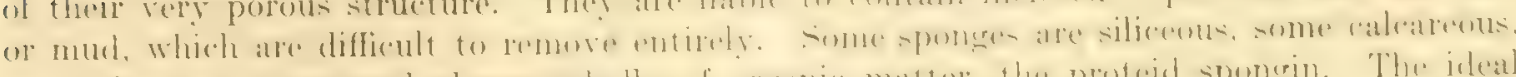

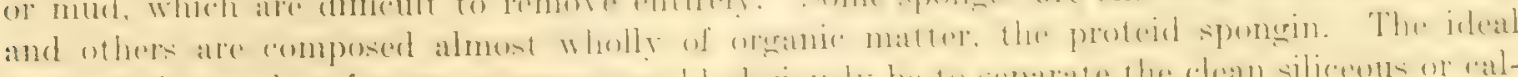

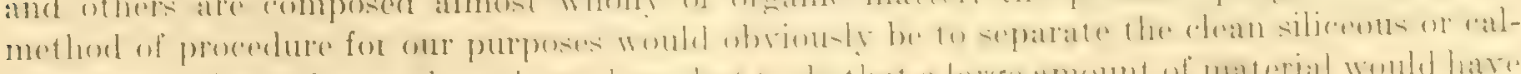

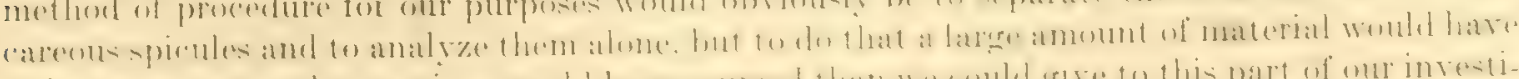

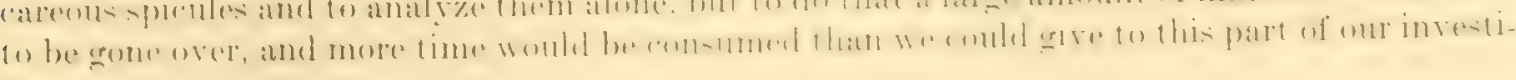

1 Brady, II. I3., Challenger lient., vol. 9, 1p. xvil-xxi, thit. 
gation. Is the sponges are of minor importance in relation to the marine sediments, we have followed our usual course, and so have obtained results which are of some significance, even if they are not all that might be desired. Twenty sponges have been examined, more or less completely, as follows:

1. Euplcctclla speriosa Quoy and (iaimard ("Venus's flower basket"). Philippine Islands.

2. Bathydorus uncifer F. E. Schulze. Galapagos Islands, Albatross station 2818 ; latitude, $0^{\circ} 29^{\prime}$ S.; longitude, $\$ 9^{\circ} 54^{\prime} 30^{\prime \prime} 11$; ; depth of water, 617.4 merers; bottom temperature, $9.9^{\circ} \mathrm{C}$.

3. Halirhondria panirca Johnston. Alaska.

4. Subcrites subcrca Johnston. Unga Island and Popot Strait, Alaska.

J. Tcthya gravala Hyatt. Buzzards Bay, Mass.

6. Pheroncma grayi kent. Off southwest coast of Ireland, at depth of 1,098 meters.

7. Geolia mesolriana var. pachana Lendenfeld. Off southern California, .1lbatross station 2909; latitude, $32^{\circ} 22^{\prime}$ $\therefore$.; longitude, $120^{\circ} 08^{\prime} 33^{\prime \prime} 1 \mathrm{~T}^{\circ}$; depth 377 meters; bottom temperature, $7.3^{\circ} \mathrm{C}$.

s. Phakellia grandis Terrill. Browns lBank, northeast of Cape Cod, between latitudes $40^{\circ} 30^{\prime}$ and $42^{\circ} 08^{\prime} \mathrm{N}^{\circ}$. and longitudes $66^{\circ} \mathrm{W}$; ; depth, 549 meters.

9. Chondrocladia ulaskensis Lambe. On beach at Unalaska, Alaska.

10. Gelliodes grandis Verrill. Gulf of Maine.

11. Experiopsis quatsinocnsis Lambe. Attu Island, Alaska.

I2. Chalina arbuseula Terrill. Outer Island, Conn.

13. Spinoselle sororia var. crispa Duchassaing and Michelotti. Harrington Sound, Bermuda.

11. Euspongia oflicinalis tubulifira var. turrita IIyatt. Harrington Sound, Bermuda.

15. II ircinia campana var. Lurrila Hyatt. Bermuda.

16. Euspongia offeinalis var. rotunda Hyatt. Xassau, Bahama Islands.

17. IIippospongia equina var. meandriformis Duchassaing and Michelotti. Nassau, Bahamas,

18. Hippospongia agaricina var. dura Hyatt. (Iff Duck Kiey, Fla., at depth of 4.6 meters.

19. II Tippospongia caniculate tar. gossypina Duchassaing and Michelotti. Off Rock Island, Fla., at depth of 7.3 meters.

20. Aplysina hirsula Hyatt. Off St. 'Thomas, Virgin Islands; depth of water, 37 to 42 meters.

21. Grantia ciliata, Fabricius. Woods Hole, Mass. Weight of sample only 0.0982 gram.

22. Leucille certcri, var. homoraphis (Polejaeff). Off Culebra Island, Porto Rico, Fish Hauk station 6090; bottom temperature, $26^{\circ} \mathrm{C}$. Weight of sample, 0.1422 gram.

Inalyses 21 and 22 by R. II. Kiamm.

The analyses were made by our usual methods; Nos. 21 and 22 were made on insufficient material and are therefore incomplete.

Analyses of sponges.

\begin{tabular}{|c|c|c|c|c|c|c|c|c|c|}
\hline & & 1 & 2 & 3 & 4 & 5 & 6 & 7 & 8 \\
\hline \multirow{2}{*}{\multicolumn{2}{|c|}{ 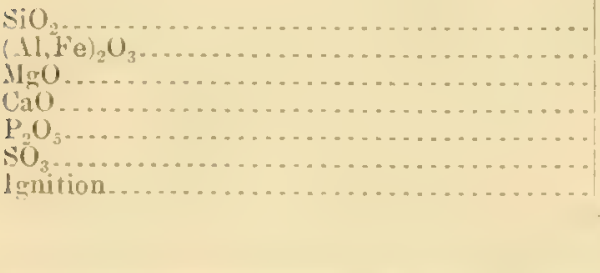 }} & $\begin{array}{r}88.56 \\
.32 \\
.00 \\
.22 \\
.00 \\
.00 \\
10.26\end{array}$ & $\begin{array}{r}76.33 \\
1.05 \\
-48 \\
2.78 \\
.00 \\
\text { Trace. } \\
18.60\end{array}$ & $\begin{array}{r}74.52 \\
6.19 \\
1.43 \\
2.33 \\
.17 \\
12.08 \\
12.11\end{array}$ & $\begin{array}{r}72.92 \\
1.22 \\
.55 \\
.33 \\
-49 \\
.39 \\
22.21\end{array}$ & $\begin{array}{r}68.46 \\
3.71 \\
.61 \\
.89 \\
.48 \\
.40 \\
23.02\end{array}$ & $\begin{array}{r}65.19 \\
3.05 \\
\text { Trace. } \\
3.26 \\
\text { Trace. } \\
.02 \\
27.05\end{array}$ & $\begin{array}{r}64.96 \\
.21 \\
-38 \\
.29 \\
\text { Trace. } \\
.21 \\
31.73\end{array}$ & $\begin{array}{r}60.70 \\
2.30 \\
.23 \\
.51 \\
.46 \\
(?)^{-4} \\
35.84\end{array}$ \\
\hline & & 99.36 & .99 .24 & 36.83 & 98.11 & 97.57 & 98.57 & 97.78 & 100.04 \\
\hline \multicolumn{10}{|l|}{4} \\
\hline \multirow[t]{2}{*}{ 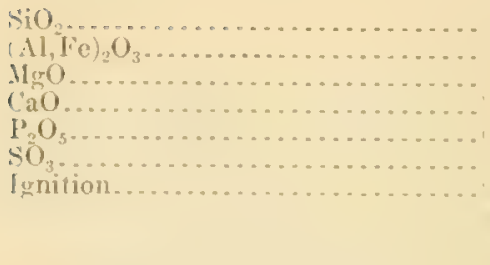 } & $\begin{array}{r}53.96 \\
1.64 \\
.55 \\
1.28 \\
-31 \\
(?) \\
11.97\end{array}$ & $\begin{array}{r}52.24 \\
3.86 \\
.86 \\
.77 \\
.61 \\
.81 \\
34.64\end{array}$ & $\begin{array}{c}51.94 \\
1.38 \\
-75 \\
1.77 \\
-46 \\
(?) \\
42.29\end{array}$ & $\begin{array}{r}31.93 \\
1.44 \\
.97 \\
.97 \\
.50 \\
.82 \\
61.25\end{array}$ & $\begin{array}{r}3.08 \\
.77 \\
.26 \\
2.80 \\
-69 \\
(?) \\
91.32\end{array}$ & $\begin{array}{r}1.31 \\
.96 \\
.43 \\
7.58 \\
.77 \\
(?) \\
89.75\end{array}$ & \begin{tabular}{r|}
0.57 \\
2.29 \\
1.60 \\
20.01 \\
.68 \\
$(?)$ \\
75.68
\end{tabular} & $\begin{array}{c}8.45 \\
1.77 \\
38.39 \\
(?) \\
.00 \\
50.31\end{array}$ & $\begin{array}{r}0.77 \\
5.50 \\
38.97 \\
(?) \\
.00 \\
53.58\end{array}$ \\
\hline & 99.74 & 93.79 & 98.59 & 97.88 & 98.92 & 100.80 & 100.83 & 98.92 & 98.82 \\
\hline
\end{tabular}


Sponges Nos. 16-20 were composed mainly of organic matter, and only loss on ignition was determined. The figures showing this loss are as follows:

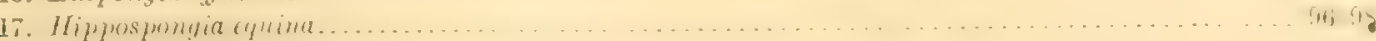

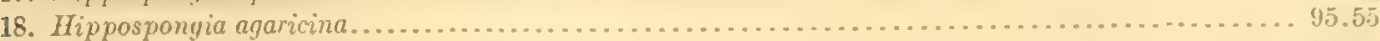

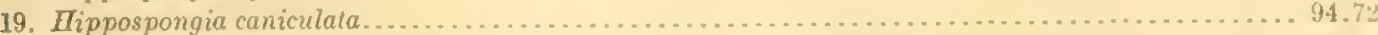

20. Aplysim hirsutı......

In these sponges the inorganic matter is so small that it may only represent impurities, an analysis of which would be meaningless. Euspongia and Hippospongia are the ordinary bath sponges of commerce.

In several of the analyses, notably in Nos. $3,5,7,10$, and 12 , the summation is very low, on account of the presence of soluble salts (sea salt), which were not determined. Analyses 1 to 12 represent silicens sponges, and in Nos. 2and to the siliceous spicules were rery comspicuons. No. 1, Euplectella, the beautiful "Venus's flower basket," may be taken as the type of these sponges, and the analysis shows that its skeleton is composed of nearly pure opaline silica. Several analyses of siliceous sponge spicules by other chemists lead to similar conclusions. In spicules from unnamed species J. Thoulet ${ }^{2}$ found from 12.88 to 13.18 per cent of water, I. L. - ichulze ${ }^{3}$ cites an analysis by Maly of spicules from Poliopogme amadou which contained 7.16 per cent, and in seven species of siliceous sponges W. J. Sollas ${ }^{4}$ found water varying from 6.1 to 7.34 per cent. In all these sponges the spicules or skeletons are composed of amorphous opaline silica. The other constituents shown in our analyses, except organic matter, which is included in the loss on ignition, are probably but not certainly impurities. To this statement one exception may be made. 'The phosphoric oxide is perhaps a part of the organisms, which contain it not as such but as phosphorus in some organic compound. 'This, however, is by no means certain. That nearly all the sponges analyzed contain phosphorus in some form, although in small amounts is clear.

Analysis No. 13, of Spinosella, is very high in organic matter, and its precise character is doubtful, at least so far as the chemical evidence goes. Nos. 14, 15, 21, and 22, however, represent calcareous sponges. Reducing the antlyses to standard form, rejecting organir matter. and recalculating to 100 per cent, we hare the following figures for their inorganic portions:

Reduced analyses of calcareous sponges.

\begin{tabular}{|c|c|c|c|c|}
\hline & 14 & 1.i. & $\because 1$ & 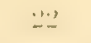 \\
\hline \multirow[t]{2}{*}{ 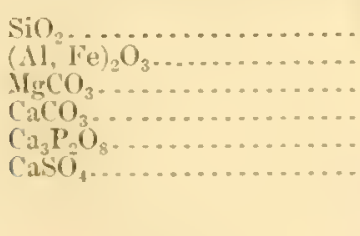 } & $\begin{array}{l}7.81 \\
5.72 \\
5.37 \\
71.14 \\
9.96 \\
(?)\end{array}$ & $\begin{array}{l}\text { 1. } 36 \\
5.45 \\
8.00 \\
81.64 \\
3.55 \\
(?)\end{array}$ & $\begin{array}{r}10.47 \\
4.61 \\
84.92 \\
(?) \\
.00\end{array}$ & $\begin{array}{r}094 \\
\text { 14. } 10 \\
84.96 \\
(?) \\
.00\end{array}$ \\
\hline & 100.00 & 100.00 & 100.00 & 100.00 \\
\hline
\end{tabular}

We can not assign much weight to these analyses, because the specimens analyzed eridently contained impurities - silica and sesquioxides. Fiven the small amounts of phosphate shown in two of them may be due to the inclosure in the sponges of minute crustaceans, such as copepods. The small percentages of $\mathrm{P}_{2} \mathrm{O}_{5}$ in the unreduced analyses are much magnified in the reduction. Some of the magnesia also may belong to inclosed sea water, and in this respect analysis No.14 is especially questionable. The presence of magnesia, however, in these sponges is somewhat

\footnotetext{
: Thoulet, J., Compt. Rend., vol. 94, p. 1000, 1tit.

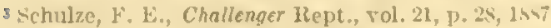

isollas, WV. J., idem, vol, 2i, p. xlviii, 1 kws.
} 
confirmed by an analysis by 0 . Bütshli of spicules from a Mediterranean spouge, Lencandra aspera. His figures are as follows:

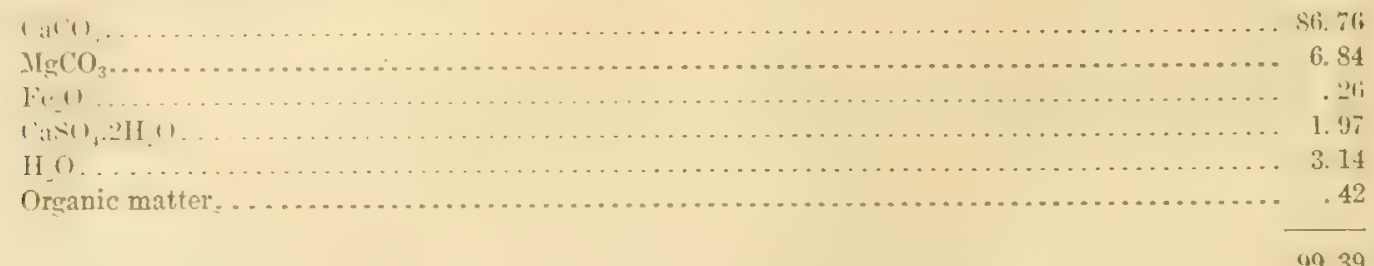

If we reject water and organic matter and recalculate to 100 per cent the percentage of magnesium carbonate rises to 7.17 . It seems probable, then, that the calcareous sponges are distinctly magnesian, although more analyses are needed to establish the fact. ${ }^{6}$

\section{MADREPORARIAN CORALS.}

Madreporarian or stony corals have been repeatedly analyzed and with generally concordant results. 'Twenty-eight of these corals were studied in the course of this investigation, and with the results two old analyses made in the laboratory of the United States Geological Survey may properly be included. The order of arrangement here is regional, for reasons which will appear later, in our study of the alcyonarians. The list of corals analyzed is as follows:

1. Balanophyllia floridana Pourtalès. South of Key West, Fla.; depth of water, 165 meters.

2. Paramathus defilipii Duchassaing and Michelotti. South of Key West; denth, 165 meters.

3. Dendrophyllia cornucopia Pourtalès. Fish Hank station 7286, Gulf Stream, off Key West; latitude, $24^{\circ} 18^{\prime} 00^{\prime \prime}$ I.; longitude, $81^{\circ} 47^{\prime} 45^{\prime \prime} \mathrm{W}$.; depth, 243 meters; bottom temperature, $11.9^{\circ} \mathrm{C}$.

4. Siderastrca radians Pallas. Shoal water, Ragged Keys, Fla.

5. Poriles furcata Lamarck. Shoal water, Ragged Keys.

6. Faria fragum Esper. Shoal water, Tortugas, Fla.

7. Eusmilia aspera Dana. Shoal water, Tortugas.

S. Oculina diffusa Lamarck. Shoal water, fortugas.

9. Cladocora arbuscula Lesueur. Tortugas; depth, 27.5 meters.

10. Agaricia purpurea Lesueur. Reef, Loggerhead Key, Tortugas.

11. Orbicella annularis Ellis and Solander. Reef, Loggerhead Key.

12. Dasmosmilia lymani Pourtalès. Albatross station 2087; latitude, $40^{\circ} 06^{\prime} 50^{\prime \prime} \mathrm{N}$.; longitude, $70^{\circ} 34^{\prime} 15^{\prime \prime} \mathrm{W}$.; 'epth, 119 meters: bottom temperature, $10^{\circ} \mathrm{C}$

13. Flabellum alabastrum Moseley. Albatross station 2677 ; latitude, $32^{\circ} .39^{\prime} \mathrm{N}$.; longitude $76^{\circ} 50^{\prime} 30^{\prime \prime} \mathrm{W}$; between the Bahamas and Cape Fear; depth, 875 meters; bottom temperature, $4.5^{\circ} \mathrm{C}$.

14. Madrepora polifera Linné. Albatross stations 2662-2672, between the Bahamas and Cape Fear; depth, 512-894 meters; bottom temperature, $6^{\circ}-7^{\circ} \mathrm{C}$

15. Dendrophyllia profunda Pourtalès. Locality, etc., as under No. 14.

16. Marlracis decactis Lyman. Shoal water, Bermuda.

17. Deltoeyathus italicus Michelotti. Albatross station 2750 ; latitude, $18^{\circ} 30^{\prime} \mathrm{X}$.; longitude, $63^{\circ} 31^{\prime} \mathrm{W}^{\top}$; depth, !us meters; bottom temperature, $7^{\circ} \mathrm{C}$.

18. Acropota cerricomis Lamarck. Shoal water, South Bight, Bahamas.

19. Urbirella cazernosa Linné. Reef, Light House Point, Andros Island, Bahamas.

20. Heandra clirosa Ellis and Solander. I.ocality as under No. 19.

21 Marndra labyrinthiformis Linné. Reef, Golding Cay, Andros Island, IBahamas.

2.2. Ifussa aft. M. dipsacea Dana. Reef, Golding Cay.

23 l'oriles clackria lamarck. Recf, Golding Cay.

2t. Porites astronides Lamarck. Reef, Golding Cay.

25. Flabellum paronium var, pariparoninum Alcock. Albatross station 40 S0; north const of Maui, IIawaiian Islands; (iepth, 326 to 369 meters; bottom temperature, $13.5^{\circ} \mathrm{C}$.

26. Madracis kauaiensis Taughan. Allutross station 3982; vicinity of hauai, Ifawaiian Islands; depth, $426-435$ meters; botton temperature, $9.1^{\circ}$

s Butschl, O., K. Gesell. Wiss. (iöttingen Alh., No. 3, 1905.

6 On manganesc and iron in sponges, see ('otte, J., soc. binlogic Compt. rend., vol. 35, p. 139, 1903. Traces ofmanaganese were noted in our own '3113] veses. 
27. Flabellum sp. Albatross station 5273; latitude, $14^{\circ} 03^{\prime} \mathrm{N}$.; longitude $120^{\circ} 27^{\prime} 45^{\prime \prime}$ E.; China Sca, near southern Luzon; depth, 102.5 meters.

28. Desmophyllum ingens Moseley. Albatross station 27S5; latitude, $48^{\circ} 09^{\prime} \mathrm{S}$; longitude, $74^{\circ} 36^{\prime}$ W.; off coast of Chile; depth, 822 meters; bottom temperature, $8.3^{\circ} \mathrm{C}$,

The actual analyses appear in the following tables. Sulphates were rarely determined, but they are unimportant.

Analyses of corals.

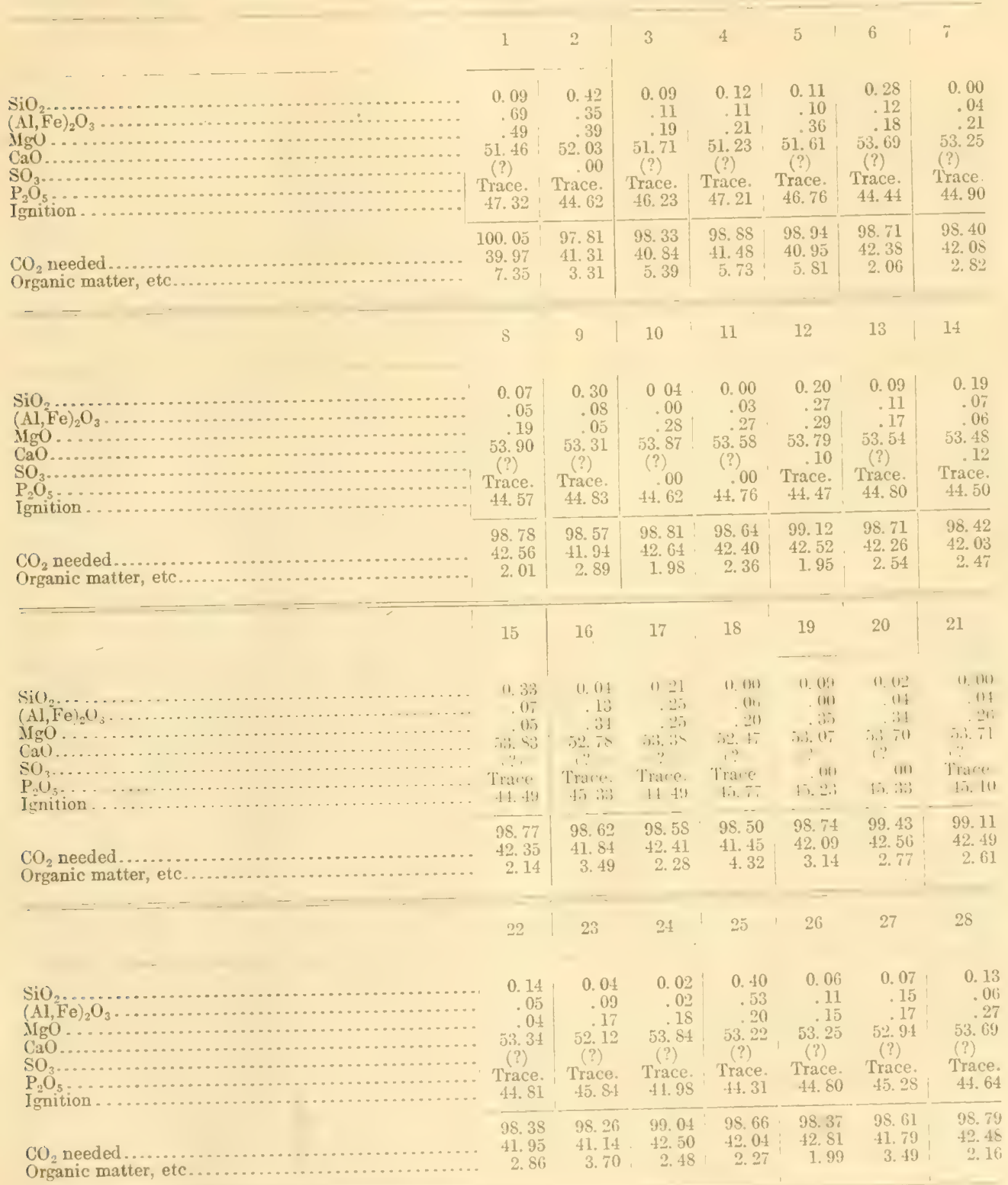


The two other analyses of corals, which were made some years ago in the Survey laboratory, do not appear in the foregoing table because they are stated in somewhat different form. They alr. lowerer, included in the following table of reduced andyses, in which the figures are recalculated to 100 pere cent and as definite salts. with organic matter and water rejected. The two in question are as follows:

29. Siderastrea sp. Bermuda; analysis by L. G. Eakins.

30. Coral, species undetermined. L'anama; analysis by W. T. Schaller.

\begin{tabular}{|c|c|c|c|c|c|c|}
\hline \multicolumn{6}{|c|}{ lieduced analyses of corals. } & \multirow{3}{*}{$\begin{array}{c}\ldots \\
6 \\
0.29 \\
.12 \\
99 \\
99.20 \\
(?) \\
\text { Trace. }\end{array}$} \\
\hline & 1 & 2 & 3 & 4 & 5 & \\
\hline \multirow[t]{3}{*}{ 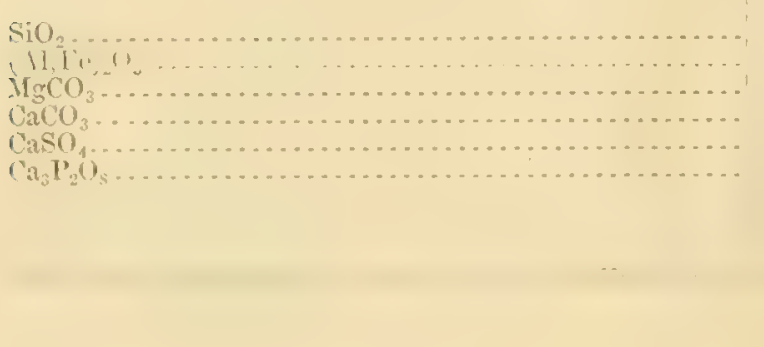 } & $\begin{array}{l}0.10 \\
.14 \\
1.11 \\
98.05 \\
\text { (?) } \\
\text { Trace. }\end{array}$ & $\begin{array}{r}0.44 \\
.34 \\
95.87 \\
932 \\
.00 \\
\text { Trace. }\end{array}$ & $\begin{array}{l}0.10 \\
.12 \\
99.43 \\
99.35 \\
(?) \\
\text { l'iace. }\end{array}$ & $\begin{array}{l}0.13 \\
.12 \\
99.48 \\
99.27 \\
(?) \\
\text { Trace. }\end{array}$ & $\begin{array}{l}0.12 \\
.11 \\
.82 \\
99.95 \\
(?) \\
\text { Trace. }\end{array}$ & \\
\hline & 100.00 & 100.00 & 100.00 & 100.00 & 100.00 & 100.00 \\
\hline & 7 & 8 & 9 & 10 & 11 & 12 \\
\hline \multirow[t]{2}{*}{ 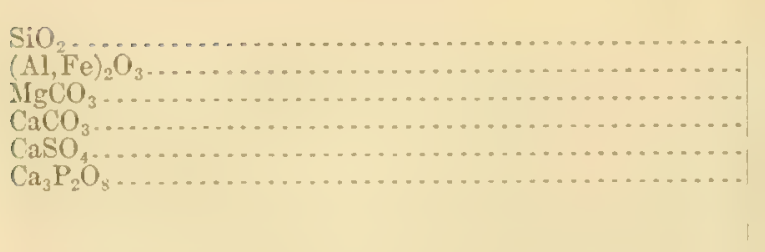 } & $\begin{array}{l}0.00 \\
.04 \\
.46 \\
99.50 \\
\text { (?) } \\
\text { Trace. }\end{array}$ & $\begin{array}{l}0.07 \\
.05 \\
.41 \\
99.47 \\
(?) \\
\text { Trace. }\end{array}$ & $\begin{array}{l}0.31 \\
.08 \\
.11 \\
99.50 \\
(?) \\
\text { Trace. }\end{array}$ & $\begin{array}{r}0.04 \\
.00 \\
.61 \\
99.35 \\
? .00\end{array}$ & $\begin{array}{r}0.00 \\
.03 \\
.59 \\
99.38 \\
(?) .00\end{array}$ & $\begin{array}{r}0.21 \\
.28 \\
.63 \\
98.71 \\
.17 \\
\text { Trace. }\end{array}$ \\
\hline & 100.00 & 100.00 & 100.00 & 100.00 & 100.00 & 100.00 \\
\hline \multirow{3}{*}{ 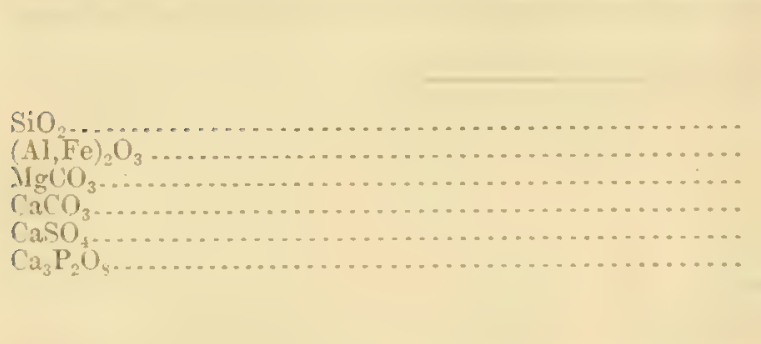 } & 13 & 14 & 15 & 16 & 17 & 18 \\
\hline & $\begin{array}{l}0.09 \\
.12 \\
.37 \\
99.42 \\
\text { (?) } \\
\text { Trace. }\end{array}$ & $\begin{array}{r}0.20 \\
.07 \\
.14 \\
99.38 \\
.21 \\
\text { Trace. }\end{array}$ & $\begin{array}{l}0.31 \\
.07 \\
.12 \\
99.47 \\
(?) \\
\text { Trace. }\end{array}$ & $\begin{array}{r}0.04 \\
.14 \\
.76 \\
99.06 \\
(?) \\
\text { Trace. }\end{array}$ & $\begin{array}{l}0.22 \\
.26 \\
.54 \\
98.98 \\
\text { (?) } \\
\text { Trace. }\end{array}$ & $\begin{array}{l}0.00 \\
.06 \\
.45 \\
99.49 \\
(?) \\
\text { Trace. }\end{array}$ \\
\hline & 100.00 & 100.00 & 100.00 & 100.00 & 100.00 & 100.00 \\
\hline \multirow{4}{*}{ 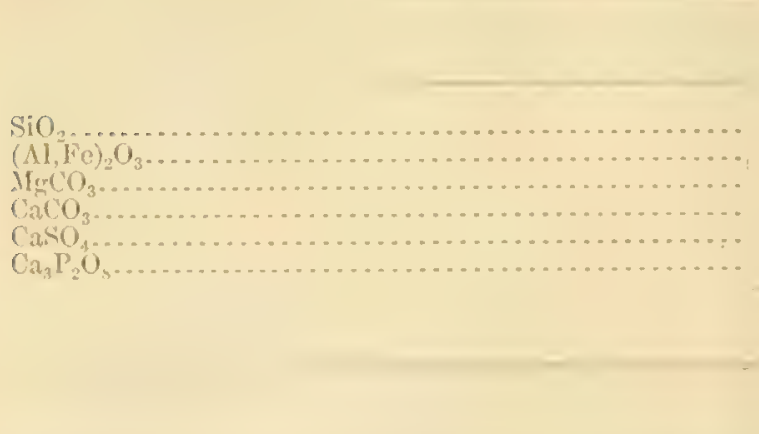 } & 19. & 20 & 21 & 22 & 23 & 24 \\
\hline & $\begin{array}{r}0.10 \\
.00 \\
.77 \\
99.13 \\
(?) .00\end{array}$ & $\begin{array}{r}0.02 \\
.04 \\
.73 \\
99.21 \\
? ? .00\end{array}$ & $\begin{array}{l}0.00 \\
.04 \\
.57 \\
99.39 \\
\text { (?) } \\
\text { Trace. }\end{array}$ & $\begin{array}{l}0.15 \\
.05 \\
.09 \\
99.71 \\
(?) \\
\text { Trace. }\end{array}$ & $\begin{array}{l}0.04 \\
.10 \\
.37 \\
99.49 \\
\text { (?) } \\
\text { Trace. }\end{array}$ & $\begin{array}{r}0.02 \\
.02 \\
.40 \\
99.56 \\
(?) \\
\text { Trace. }\end{array}$ \\
\hline & 100.00 & 100.00 & 100.00 & 100.00 & 100.00 & 100.00 \\
\hline & 25 & 26 & 27 & $2 \mathrm{~S}$ & 29 & 30 \\
\hline \multirow[t]{2}{*}{ 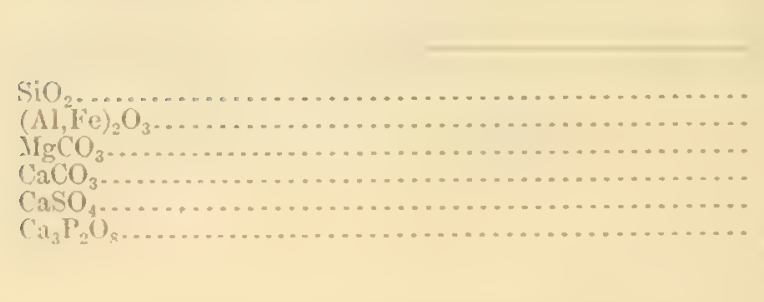 } & $\begin{array}{l}0.41 \\
.55 \\
9.43 \\
98.61 \\
(?) \\
\text { Trace. }\end{array}$ & $\begin{array}{l}0.06 \\
.11 \\
.33 \\
99.50 \\
\text { (?) } \\
\text { Trace. }\end{array}$ & $\begin{array}{r}0.07 \\
.15 \\
.37 \\
99.41 \\
\text { (?). } \\
\text { Trace. }\end{array}$ & $\begin{array}{l}0.14 \\
.06 \\
.59 \\
99.21 \\
(?) \\
\text { Trace. }\end{array}$ & $\begin{array}{c}0.23 \\
\text { Trace. } \\
.42 \\
99.35 \\
(?) \\
(?)\end{array}$ & $\begin{array}{r}1.25 \\
.59 \\
.59 \\
97.57 \\
(?) \\
(?)\end{array}$ \\
\hline & 100.00 & 100.00 & 100.00 & 100.00 & 100.00 & 100.00 \\
\hline
\end{tabular}


'These analyses are remarkably concordant and show that the stony corals contain little besides calcium carbonate. Silica and sesquioxides aro probably extraneous; magnesia is altogether subordinate, although fairly regular in its anount; phosphates occur only in traces. The older analyses all tell the same story, except that in six analyses by S. P. Sharples ${ }^{7}$ of corals from the Gulf Stream from 0.27 to 0.84 per cent of calcium phosphate was determined. In five analyses of Brazilian corals, L. R. Lenox ${ }^{8}$ found from 0.42 to 0.54 per cent of magnesium carbonate, quantities like those appenring in our tables. In short, the uniformity of the data is so marked that it is unnecessary to reproduce all the published analyses here.?

\section{ALCYONARTAN CORAIS.}

'The alcyonarians, which include the red corals, the gorgonias, or sea fans, and other similar, generally branching forms, differ from the madrepores in being notably magnesian. To this rule one exception is known, the genus Hetiopora, which stands quite alone and resembles the ordinary corals not only in structure but also in chenical composition. ${ }^{10}$ With this exception, the alcyonaria are chemically similar to the crinoids, but some genera are much richer in phosphates. In some respects the alcyonarians are difficult to deal with analytically, for many of them have a horny axis, composed chiefly of organic matter, surrounded by a cortex or enrelope which is largely calcareous. These two portions of the structure are so unlike in composition that imperfections in a sample taken for analysis may lead to very uncertain conclusions.

'The list of alcyonarians analyzed is as follows:

1. Heliopora cerulea Pallas; blue coral. Southern Philippine Islands. The blue color consists of organic matter."

2. Tubipora purpurca Lamarck. Singapore, Straits Settlements; latitude, $1^{\circ} 20^{\prime} \mathrm{N}$.; longitude, $103^{\circ} 50^{\prime} \mathrm{E}$.

3. Corallium elatior Ridley; a red coral. Murotsu, 'Tosa (Shikoku), Japan; latitude, about $33^{\circ} \mathrm{N}$.

4. Primnoa reseda Verrill. East of Nova Scotia; depth of water, 366 meters; latitude, $42^{\circ} 16^{\prime} \mathrm{N}$.; longitude, $63^{\circ} 15^{\prime} 1 \mathrm{~W}^{\prime}$.

5. Lepidisis caryophyllia Verrill. Off Nantucket Shoals, . Ilbatross station 2037; latitude, $38^{\circ} 53^{\prime} 00^{\prime \prime} \mathrm{N}^{*}$; longitude, $69^{\circ} 23^{\prime} 30^{\prime \prime} \mathrm{W}$.; depth, 3,168 meters; bottom temperature, $3.3^{\circ} \mathrm{C}$.

6. Pennatula aculeata Dana. St. Peters Bank and Banquereau; Albatross station 2470; latitude, $44^{\circ} 47^{\prime} \mathrm{N}$. longitude, $56^{\circ} 33^{\prime} 45^{\prime \prime} \mathrm{W}$; depth, 410 meters; bottom temperature, $4.5^{\circ}$

7. Paramuricen borealis Verrill. Southwest edge of the Grand Banks; depth, 641 to 732 meters.

8. Paragorgia arborea Milne-Edwards and Haime. La Have Ridge, off Nova Scotia.

9. Alcyonium carneum 1. Agassiz. Albatross station 2468, ofl Newfoundland; latitude, $45^{\circ} 11^{\prime} 30^{\prime \prime}$ N.; longitude, $55^{\circ} 51^{\prime} 30^{\prime \prime} \mathrm{W}$; depth, 70.9 meters; bottom temperature, $0.5^{\circ} \mathrm{C}$. This analysis, of very pure material, replaces the unsatisfactory one given in the former edition of this paper. Analyst, R. H. Kamm.

10. Gorgonia suffruticosa Dana. Fiji Islands. Cortex and axis together.

11. Gorgonia acerosa Pallas. East end of Long Cay, Nassau, Bahamas; latilude, $25^{\circ} 5^{\prime} 6^{\prime \prime} \mathrm{N}$. Cortex and axis.

12. Gorgonia acerosa. Caesars Creek, southern Florida; latitude, $23^{\circ} 30^{\prime} \mathrm{N}$. approximately. Cortex alone.

13. Muricce humilis Milne-Edwards. Parahyba do Norte, Brazil; latitude, $7^{\circ}$ to $\mathrm{S}^{\circ} \mathrm{s}$.

14. Muricea echinata Valenciennes. Cape San Lucas, Lower California; latitude, $22^{\circ} 52^{\prime} X^{\prime}$.

15. Plexaurella grandiflora Verrill. Mar Grande, Bahia, Brazil.

16. Ctenocella pecinnia Valenciennes. Torres Straits, Australia; latitude, about $10^{\circ} \mathrm{S}$.

17. Xiphogorgin anceps Pallas. Caesars Creek, southern Florida; latitude, $23^{\circ} 30^{\prime} \mathrm{X}$., approximatcly.

18. Rhipidogorgia fabellum Linné. Bermuda; latitude, about $32^{\circ} \mathrm{N}$.

19. Rhipidogorgia flabellum. East side of Andros 1sland, Bahamas; latitude, about $25^{\circ} \mathrm{N}$.

20. Leplogorgua pulchra Verrill. La Paz, Gulf of California; latitude, "2t $0^{\circ} 20^{\prime} \mathbf{N}$.

21. Leptogorgia rigida Verrill. Cape San Lucas, Lower California; latitude, $22^{\circ} 52^{\prime} \mathrm{N}$.

22. Phyllogorgia quercifolia Dana. Fernando de Noronha, Brazil; latitude, $3^{\circ} 50^{\prime}$ s.; longitude, $32^{\circ} 25^{\prime} 11^{\circ}$.

? Sharples, S. P., Am. Jour. Sci., 3d ser., vol. 1, p. 168, 1 isil.

¿ Lenox, L. R., Harvard Coll. Mus. Comp. Zool. Bull., vol. H4, p. 25i, 1904, It a memair by J, C. I3ranner on sandstono recfs.

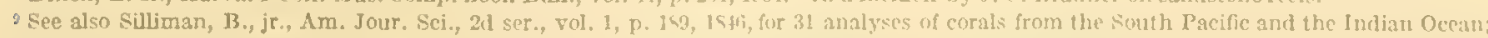

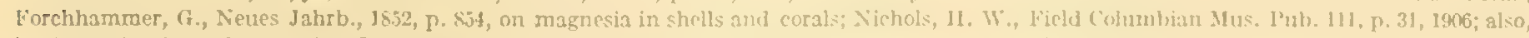
for determinations of magnesia. In Calarin d.xdalea from Abyssinia Nichols found $0.3 j$ per cent of $\mathrm{MgCO}$. A. A. Högbom, (Neues Jahrb., 1594, Band 1, p. 262) in two Bermuda corals found 0.36 and 0.62 per eent of $\mathrm{MgCO}$.

10 See Mcoseley, 11. W., l'hilos. Trans., vol. 1fit, 5.91 , 15i6, on the structural relations of Melinpura.

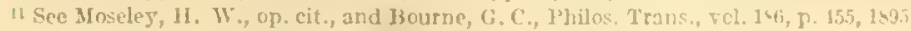


Analyses of alcyonarians.

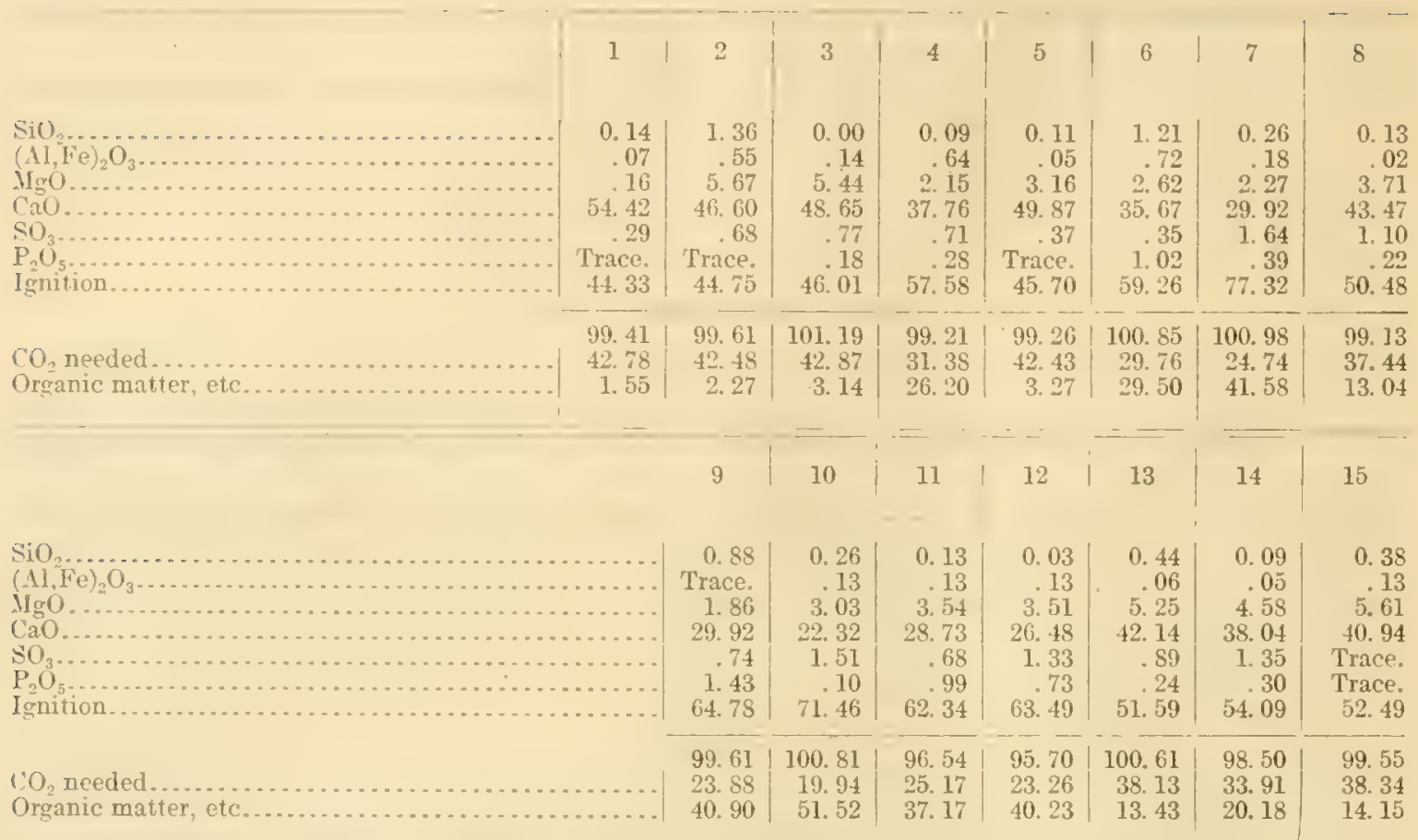

The low summation of Nos. 11 and 12 is due to inclosed or adherent sea salts. In No. 12 the amount of water-soluble matter was determined and proved to be 4.71 per cent, of which 0.55 per cent was $\mathrm{SO}_{3}$. Applying these corrections to the analysis the summation becomes 99.96.

\begin{tabular}{|c|c|c|c|c|c|c|c|}
\hline & 16 & 17 & 18 & 19 & 20 & 21 & 22 \\
\hline 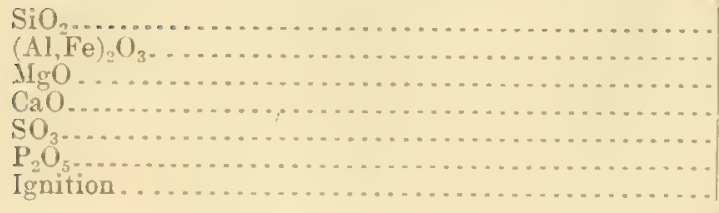 & $\begin{array}{r}0.17 \\
.10 \\
5.90 \\
37.05 \\
.79 \\
.32 \\
56.15\end{array}$ & $\begin{array}{r}0.08 \\
.04 \\
3.52 \\
27.19 \\
1.28 \\
.51 \\
65.56\end{array}$ & $\begin{array}{r}0.12 \\
.16 \\
3.42 \\
27.41 \\
.80 \\
.28 \\
65.67\end{array}$ & $\begin{array}{r}0.16 \\
.06 \\
4.22 \\
32.23 \\
1.17 \\
.86 \\
62.10\end{array}$ & $\begin{array}{r}0.06 \\
.02 \\
4.60 \\
33.59 \\
1.21 \\
2.67 \\
55.89\end{array}$ & $\begin{array}{r}0.21 \\
.16 \\
5.14 \\
36.15 \\
.93 \\
2.78 \\
55.39\end{array}$ & $\begin{array}{r}0.26 \\
.19 \\
5.59 \\
34.62 \\
.93 \\
2.97 \\
55.28\end{array}$ \\
\hline $\begin{array}{l}\mathrm{CO}_{2} \text { needed......... } \\
\text { Organic matter, etc. }\end{array}$ & $\begin{array}{r}100.48 \\
34.87 \\
21.28\end{array}$ & $\begin{array}{l}98.18 \\
24.07 \\
41.49\end{array}$ & $\begin{array}{l}97.86 \\
25.60 \\
40.07\end{array}$ & $\begin{array}{r}100.80 \\
28.51 \\
33.59\end{array}$ & $\begin{array}{l}98.04 \\
28.31 \\
27.58\end{array}$ & $\begin{array}{r}100.76 \\
30.96 \\
24.43\end{array}$ & $\begin{array}{l}99.84 \\
34.14 \\
21.14\end{array}$ \\
\hline
\end{tabular}

The reduced or rational analyses are as follows:

Reduced analyses of alcyonarians.

\begin{tabular}{|c|c|c|c|c|c|c|c|c|}
\hline & 1 & 2 & 3 & 4 & 5 & 6 & 7 & 8 \\
\hline \multirow[t]{2}{*}{ 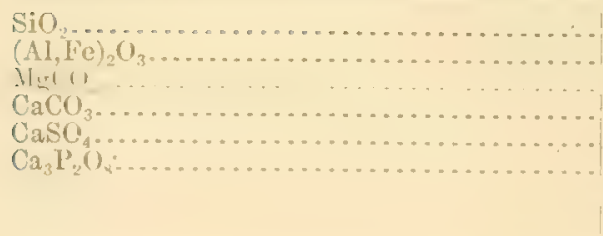 } & $\begin{array}{r}0.15 \\
.07 \\
98.93 \\
. .50 \\
\text { Trace. }\end{array}$ & $\begin{array}{r}1.40 \\
1: 57 \\
84.61 \\
1.19 \\
\text { Trace. }\end{array}$ & $\begin{array}{r}0.00 \\
.15 \\
11.56 \\
86.57 \\
1.32 \\
. .40\end{array}$ & $\begin{array}{r}0.13 \\
.88 \\
6.18 \\
90.39 \\
1.59 \\
.83\end{array}$ & $\begin{array}{r}0.11 \\
.05 \\
6.92 \\
92.24 \\
.68 \\
\text { Trace. }\end{array}$ & $\begin{array}{r}1.70 \\
1.01 \\
75.71 \\
852 \\
3.12\end{array}$ & $\begin{array}{r}0.44 \\
.30 \\
8.03 \\
85.11 \\
4.69 \\
1.43\end{array}$ & $\begin{array}{r}0.15 \\
.03 \\
9.05 \\
88.04 \\
2.17 \\
.56\end{array}$ \\
\hline & 100.00 & 100.00 & 100.00 & 100.00 & 100.00 & 100.00 & 100.00 & 100.00 \\
\hline
\end{tabular}


Roduccel erenlysis of alcyonarions-Continued.

\begin{tabular}{|c|c|c|c|c|c|c|c|}
\hline \multirow{3}{*}{ 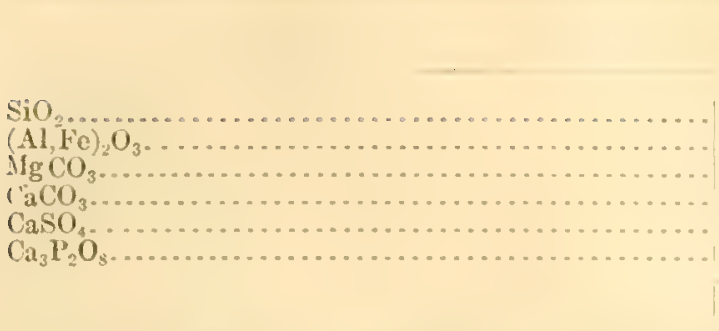 } & 9 & 10 & 11 & 12 & 13 & 14 & 15 \\
\hline & $\begin{array}{r}1.50 \\
\text { Trace. } \\
6.66 \\
54.50 \\
2.15 \\
5.19\end{array}$ & $\begin{array}{r}0.55 \\
.25 \\
13.43 \\
79.84 \\
5.43 \\
.47\end{array}$ & $\begin{array}{r}0.22 \\
.22 \\
12.52 \\
81.45 \\
1.95 \\
3.64\end{array}$ & $\begin{array}{r}0.01 \\
.24 \\
13.29 \\
79.48 \\
4.08 \\
2.87\end{array}$ & $\begin{array}{r}0.50 \\
12.07 \\
84.47 \\
1.73 \\
.54\end{array}$ & $\begin{array}{r}0.11 \\
.06 \\
12.28 \\
83.79 \\
2.93 \\
.83\end{array}$ & $\begin{array}{r}0.45 \\
13.79 \\
85.61 \\
\text { Trace. } \\
\text { Trace. }\end{array}$ \\
\hline & 100.00 & 100.00 & 100.00 & 100.00 & 100.00 & 100.00 & 100.00 \\
\hline & 16 & 17 & 18 & 19 & 20 & 21 & 22 \\
\hline \multirow[t]{2}{*}{ 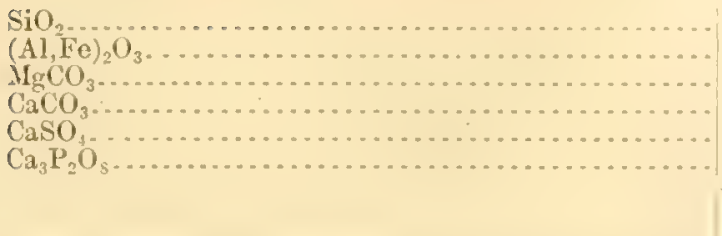 } & $\begin{array}{r}0.21 \\
15.65 \\
81.44 \\
1.69 \\
.88\end{array}$ & $\begin{array}{r}0.14 \\
13.07 \\
80.94 \\
3.83 \\
1.96\end{array}$ & $\begin{array}{r}0.21 \\
.28 \\
12.64 \\
83.38 \\
2.40 \\
1.09\end{array}$ & $\begin{array}{r}0.24 \\
.07 \\
13.19 \\
80.75 \\
2.95 \\
2.80\end{array}$ & $\begin{array}{r}0.09 \\
.03 \\
13.71 \\
74.99 \\
2.91 \\
8.27\end{array}$ & $\begin{array}{r}0.28 \\
.21 \\
14.13 \\
75.36 \\
2.07 \\
7.95\end{array}$ & $\begin{array}{r}0.34 \\
15.73 \\
72.99 \\
2.11 \\
8.57\end{array}$ \\
\hline & 100.00 & 100.00 & 100.00 & 100.00 & 100.00 & 100.00 & 100.00 \\
\hline
\end{tabular}

Analysis No. 1, that of Heliopora, might be an analysis of an ordinary coral, being nearly nonmagnesian and hence different from the others.

In two of the Gorgonias the black wiry axis was separately analyzed, although the amount of material was very small. The axis of a Rhipidogorgia sp. from Bermuda was also studied and to better advantage. The three analyses are as follows:

\begin{tabular}{|c|c|c|c|}
\hline & $\begin{array}{l}\text { Gorgonia } \\
\text { acerosa. }\end{array}$ & $\begin{array}{c}\text { Gorgonia } \\
\text { suffruticosa. }\end{array}$ & $\begin{array}{l}\text { Rhipido- } \\
\text { gorgia? }\end{array}$ \\
\hline \multirow[t]{2}{*}{ 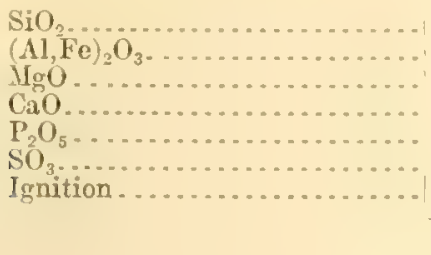 } & $\begin{array}{r}0.04 \\
.10 \\
.71 \\
.53 \\
.31 \\
.94 \\
96.45\end{array}$ & $\begin{array}{r}0.39 \\
.06 \\
.80 \\
1.10 \\
\text { Trace. } \\
1.65 \\
94.39\end{array}$ & $\begin{array}{r}0.07 \\
\text { Trace } \\
1.03 \\
.50 \\
.15 \\
1.90 \\
95.83\end{array}$ \\
\hline & 99.08 & 98.39 & 99.48 \\
\hline
\end{tabular}

The axes, evidently, are composed largely of organic matter, and the inorganic portions differ in composition from the more abundant calcareous envelopes. In two of them magnesia is in excess of lime, and in all three the sulphates are conspicuous. To determine the exact chemical nature of these axes would require much material and a longer investigation than we are justified in attempting.

A specimen of Leptogorgia flamnea Verrill, from the Cape of Good Hope, was also examined, but it was not sufficiently perfect. Much of the cortex had been broken away, leaving an excess of the axis. The partial results obtained, however, showed an exceedingly high proportion of phosphates, and a complete study of the species is much to be desired. Indeed, the genus Leptogorgia well deserves an exhaustive inrestigation, but perhaps more on biological than on geological grounds. The fact that it contributes both magnesium carbonate and calcium phosphate to the marine sediments seems to be established.

Several other analyses of alcyonarians, partial or complete, are on record, and three of them deserve reproduction here. The data are as follows:

1. Pleurocorallium johnsoni Gray. From latitude $25^{\circ} 45^{\prime} \mathrm{N}$.; longitude $20^{\circ} 12^{\prime} \mathrm{W}$., about 160 miles southwest of the Canary Islands; depth of water, 2,791 meters. At that depth the temperature must have been very low, probahly not much above $0^{\circ} \mathrm{C}$. Analysis by Aaderson in Challenger Report, Deep-sea Deposits, p. $465,1891$. 
2. Alcyonium palmaium. Probably Mediterranean.

3. Corallium rubrum; the precious red coral. Mediterranean.

Analyses 2 and 3 by O. Bütschli in K. Gesell. Wiss. Göttingen Abh., No, 3, 1908.

Older analyses of alcyonarians.

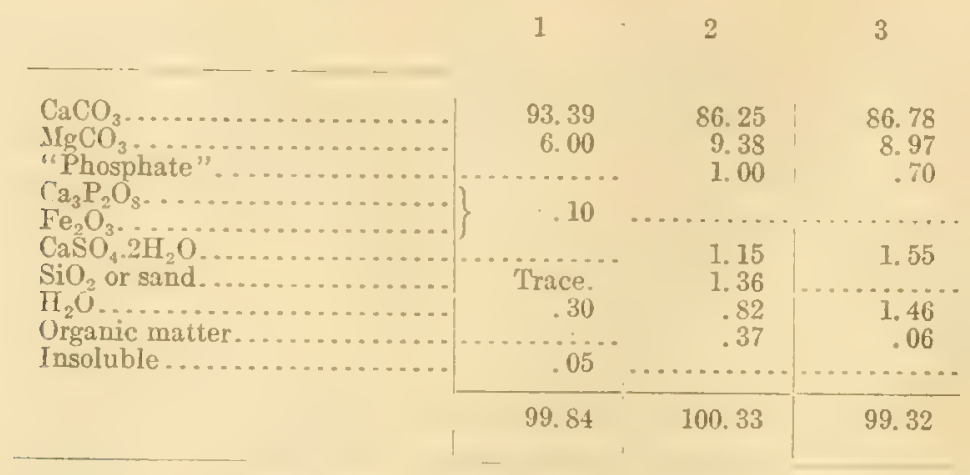

The reduced analyses, rejecting obvious impurities, are as follows:

Reduced analyses of alcyonarians.

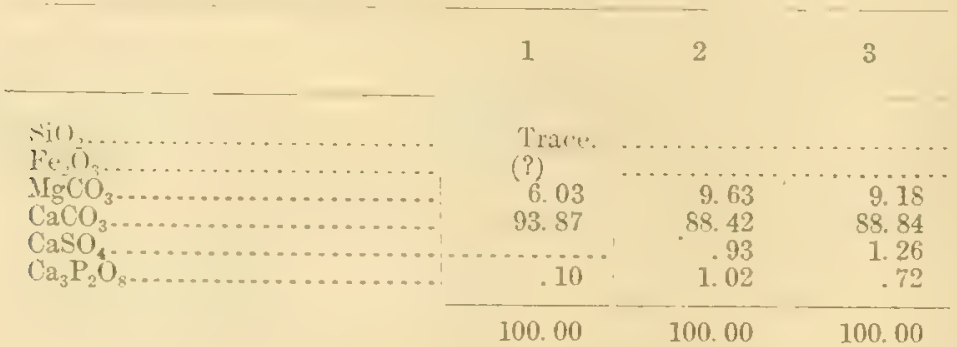

That these analyses fit well into our own series is erident.

In a worked specimen of Corallium rubrum, H. W. Nichols found 9.32 per cent of magnesium

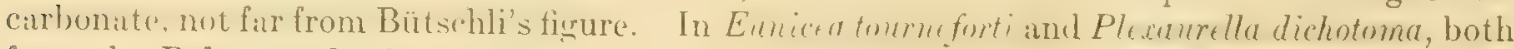
from the Bahamas, he found, respectively, 2.78 and 2.11 per cent. These percentages, however, are based on crude material; that is, without rejection of organic matter and water. They are, therefore, unavailable for comparison with our reduced analyses. Three similar analyses by G. Forchhammer ${ }^{12}$ are also recorded, of Tubipora musica, Corallium nobile $(=C$. rubrum), and Isis hippuris, which gave, respectively, 3.83, 2.73, and 6.36 per cent of magnesium carbonate. These data lack sufficiently explicit details to admit of comparison with ours. Why his figure for the red coral is so low is not clear. The material taken for analysis must have been quite different from that used by Nichols or Bütschli. A still earlier analysis of red coral by Witting ${ }^{13}$ gave 3.50 per cent of magnesium carbonate. The specimen analyzed, however, contained about 12 per cent of impurities.

If, now, we arrange the alcyonarians in the order of ascending magnesium carbonate, a remarkable relation connecting composition with temperature appears. Heliopora, being anomalous, is not included in the table. The three analyses by Anderson and Bütschli are, however, inserted. Localities and latitudes are abbreviated. The percentages of magnesium carbonate are from the reduced analyses, and those of calcium phosphate are also given. 
Magnesium carbonate and calcium phosphale in alcyonarians.

Species.
Locality.
Latitude.

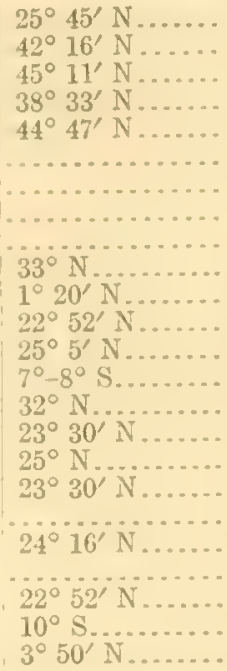

$\mathrm{Ca}_{3} \mathrm{P}_{2} \mathrm{O}_{8}: \mathrm{MgCO}_{3}$.

\begin{tabular}{r|r}
0.10 & 6.03 \\
.83 & 6.18 \\
5.19 & 6.66 \\
Trace. & 6.92 \\
3.12 & 7.71 \\
1.43 & 8.03 \\
.56 & 9.05 \\
.72 & 9.18 \\
1.02 & 9.63 \\
.40 & 11.56 \\
Trace. & 12.23 \\
.83 & 12.29 \\
3.64 & 12.52 \\
.59 & 12.64 \\
1.09 & 12.64 \\
1.96 & 13.04 \\
2.80 & 13.19 \\
2.87 & 13.29 \\
.47 & 13.43 \\
8.27 & 13.71 \\
Trace. & 13.79 \\
7.95 & 14.13 \\
.88 & 15.65 \\
8.57 & 15.73 \\
&
\end{tabular}

Since the foregoing table was compiled Prof. L. R. Cary, of Princeton University, has kindly sent me a series of unpublished analyses of alcyonirian -ipicules from specimens collected in shallow reefs around the 'Tortugas and southern Florida. The spicules were separated from organic matter by treatment with a strong solution of caustir: sendit andsubsequent wilshing with rain water until they were freed from impurities. The analyses, by Prof. $\mathbf{A}$. H. Phillips, are as follows:

Analyses of alcyonarian spicules from the Tortugas and southern Florida.

\begin{tabular}{|c|c|c|c|c|}
\hline Species. & $\mathrm{CaCO}_{3}$. & $\mathrm{IgCO}_{3}$. & $\mathrm{Ca}_{3} \mathrm{P}_{2} \mathrm{O}_{8}$ & Sum. \\
\hline 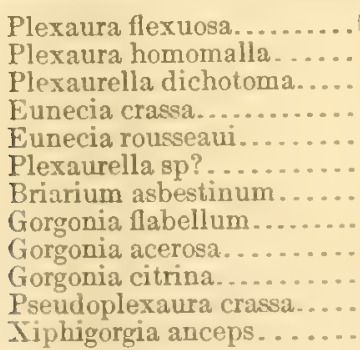 & $\begin{array}{l}80.87 \\
86.29 \\
85.90 \\
87.27 \\
86.76 \\
86.75 \\
85.13 \\
86.04 \\
85.76 \\
85.29 \\
86.71 \\
84.91\end{array}$ & $\begin{array}{l}16.90 \\
12.01 \\
14.12 \\
11.46 \\
11.45 \\
12.05 \\
13.21 \\
13.12 \\
13.39 \\
13.43 \\
12.12 \\
13.23\end{array}$ & $\begin{array}{l}0.35 \\
.04 \\
.09 \\
.09 \\
.12 \\
.15 \\
.13 \\
.44 \\
.44 \\
.22 \\
.19 \\
.26\end{array}$ & $\begin{array}{r}95.13 \\
93.31 \\
100.11 \\
93.82 \\
98.31 \\
95.98 \\
95.41 \\
99.60 \\
99.59 \\
98.94 \\
99.02 \\
98.40\end{array}$ \\
\hline
\end{tabular}

These analyses admirably confirm the analyses, made in the Survey laboratory, of alcyonarians from the same region and the Bahamas. In addition, Prof. Phillips made a partial analysis of spicules from Alcyonium rigidum from Samoa, in which he found 10.50 per cent of magnesium carbonate.

Although records of temperature and depths are available for only a few of these alcyonarians, the suggested relation is clearly esilent. The rimisms from cold, nerthern waters or" from very deep waters are low in magnesia, and those from warm regions are high. 'Ihe same

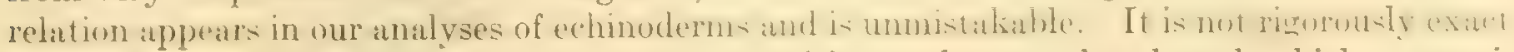
but some apparent irregularities are due to impurities, such as sand and mud, which appear in the analyses as silica and sesquioxides. If these were rejected the percentage of magnesia 
would be raised. Variations are also to be expected because of cold or warm currents and different depths of water. Very deep water, even under the Equator, is always cold, whereas shallow bays farther north may he relatirely warm. Possibly, also, the alcyonarians may form two or more distinct series that are not perfectly comparable in chemical composition. Corallium and Thbipora, for example, are compact forms, with little organic matter and lower magnesia than the genera with horny, organic axes, such as those whose names appear at the end of the table. It is also noteworthy that the highest proportions of calcium phosphate are commonly associated with a high content of magnesia.

\section{HYDROIDS.}

In the course of this investigation six analyses have been malc of coralline hydroids belonging to the genera Mfillepora and Distichopora. The species and localities are as follows:

1. Millepora alcicornis Linné. Shoal water, Tortugas, Fla.

2. Millepora alcicornis. Bermuda.

3. Millepora braziliensis Verrill. Candeas, Pernambuco, Brazil.

4. Distichopora nitida Verrill. Micronesia, exact locality unknown.

5. Distichopora coccinea Gray. South Sea Islands, exact locality unknown.

6. Distichopora sulcata Pourtalès. Off Habana, Cuba; depth of water, 143 to 179 meters.

Analyses of hydroids.

\begin{tabular}{|c|c|c|c|c|c|c|}
\hline & 1 & 2 & 3 & 4 & 5 & 6 \\
\hline 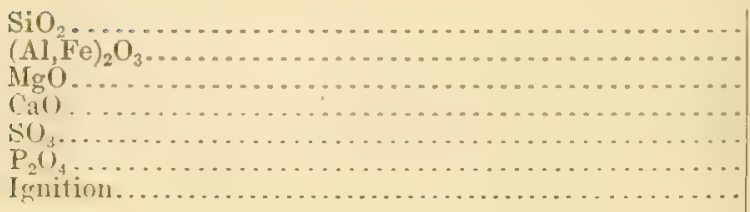 & $\begin{array}{r}0.23 \\
.10 \\
.43 \\
52.50 \\
.27 \\
\text { Trice } \\
41.77\end{array}$ & $\begin{array}{r}0.02 \\
.07 \\
.10 \\
53.14 \\
.04 \\
\text { Trace. } \\
4.5 .16\end{array}$ & $\begin{array}{r}0.09 \\
.06 \\
.59 \\
53.36 \\
1.03 \\
\text { Trace. } \\
44.87\end{array}$ & $\begin{array}{r}0.10 \\
.20 \\
.11 \\
53.07 \\
.69 \\
\text { Trace. } \\
44.89\end{array}$ & $\begin{array}{r}0.09 \\
.07 \\
.12 \\
53.43 \\
.65 \\
\text { Trace. } \\
45.05\end{array}$ & $\begin{array}{r}0.07 \\
.05 \\
.12 \\
53.90 \\
.61 \\
\text { Trace. } \\
45.37\end{array}$ \\
\hline 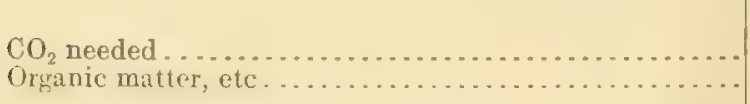 & $\begin{array}{r}95.30 \\
41.57 \\
3.20\end{array}$ & $\begin{array}{r}93.53 \\
41.85 \\
3.31\end{array}$ & $\begin{array}{r}100.00 \\
42.01 \\
2.86\end{array}$ & $\begin{array}{r}99.06 \\
41.44 \\
3.45\end{array}$ & $\begin{array}{r}99.41 \\
41.76 \\
3.29\end{array}$ & $\begin{array}{r}100.12 \\
42.15 \\
3.22\end{array}$ \\
\hline
\end{tabular}

Reduced analyses of liydroids:

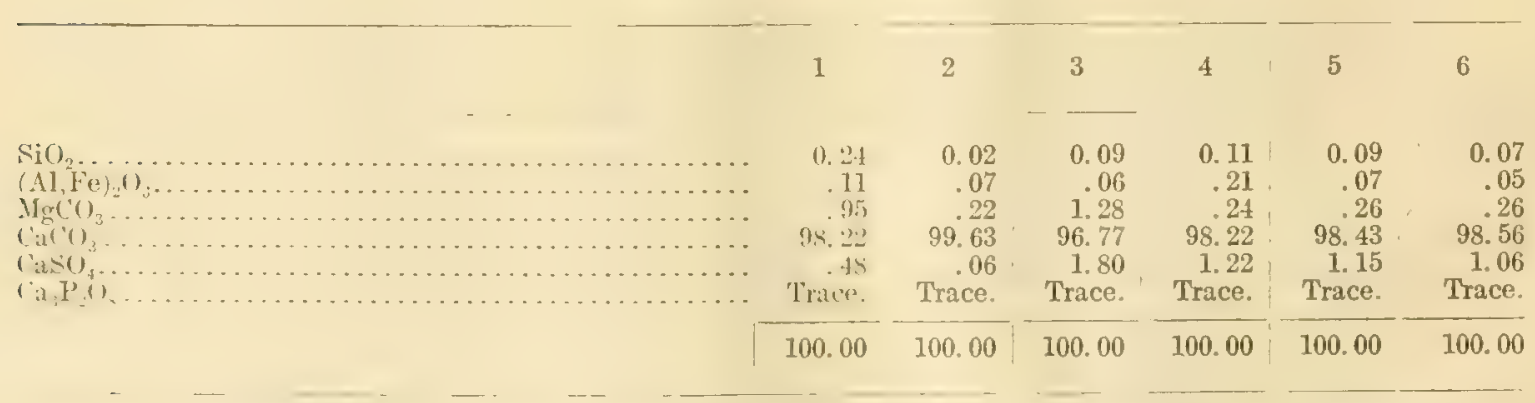

A few partial analyses and one fairly complete analysis of millepores have already been published. which in all important particulars agree with ours. The coralline structures consist essentially of calcium carbonate, with minor impurities, and resemble chemically the true corals. In two millepores from Bermuda A. G. Högbom ${ }^{\text {is }}$ found respectively 95.86 and 94.39 per cent of calcium carbonate, with 0.41 and 0.97 of magnesium carbonate. In Millepora alcicornis from the Gulf Stream S. P. Sharples ${ }^{15}$ found 97.45 per cent of calcium carbonate, 0.27 of calcium phosphate, 2.54 of organic matter and water, and only traces of iron and magnesia. B. Silliman, $\mathrm{jr}_{0}{ }^{16}$ in one analysis of the same species reported no magnesia, which evidently

14 Ilögbom, A. G., Neues Jahrb., 1S94, Band 1, p. 262.
1s Sharples, S. P., Im. Jour. Sci., 3d ser., vol, 1, p. 168, 1871. 
was not sought for. A single analysis of Mr. braziliensis by $\mathrm{L}$. R. L.enox ${ }^{12}$ gave the following composition:

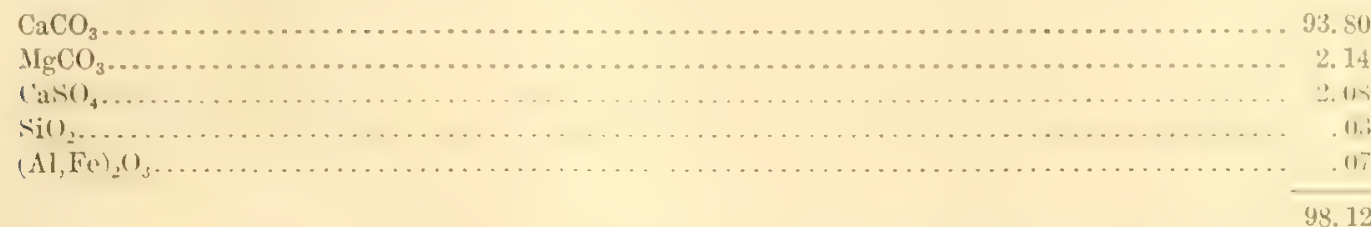

It is interesting to note that the Brazilian species is the richest of all in magnesia, although it is poor in comparison with the echinoderms and alcyonarians. As reef builders the millepores contribute little to the coral rock but carbonate of lime.

In an analysis of Millepora cervicornis, by $A$. Damour, ${ }^{18} 8.51$ per cent of magnesium carbonate is reported. The name, however, belongs to a fossil species, and the specimen analyzed was at least partly fossilized. Its locality is giren as Bréhat, Manche, France.

\section{ANNHIIDS.}

The curious tubes formed by marine worms probably contribute little to the sediments. They are, however, of some interest in an investigation of this kind, and for that reason six analyses of them have been made, as follows:

1. Filograna implexa Berkeley (Serpula complexa). Scarborough, England.

2. Protula tabularia (Montagu) (Serpula tabularia). Locality unknown, probably British.

3. Iydroides dianthus Verrill. Vineyard Sound, Mass,

4. Leodice polybranchia Verrill. Off Marthas Vineyard, Mass.

5, 6. Hyalinocia artifex Verrill. Off Marthas Vineyard, Fish Hawk station 1025; depth of water, 384 meters; bottom temperature, $7^{\circ} \mathrm{C}$. Two analyses, of different samples; the tubes of this annelid, on ignition, gave an inorganic residue which fused to a white, porcelain-like mass.

Analyses of worm tubes.

\begin{tabular}{|c|c|c|c|c|c|c|}
\hline & 1 & 2 & 3 & 4 & 5 & 6 \\
\hline 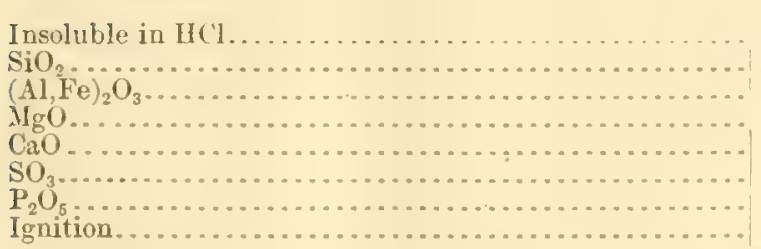 & $\begin{array}{r}29.82 \\
1.12 \\
.75 \\
.00 \\
35.98 \\
\text { Trace. } \\
.29 \\
31.23\end{array}$ & $\begin{array}{r}0.75 \\
.41 \\
.14 \\
50.89 \\
.07 \\
\text { Trace. } \\
45.99\end{array}$ & $\begin{array}{r}15.45 . \\
1.30 \\
3.58 \\
39.11 \\
\text { Trace. } \\
.22 \\
38.82\end{array}$ & $\begin{array}{r}28.05 \\
2.33 \\
4.40 \\
5.12 \\
6.06 \\
6.43 \\
46.91\end{array}$ & $\begin{array}{r}0.20 \\
.07 \\
8.57 \\
5.35 \\
3.47 \\
20.72 \\
61.83\end{array}$ & $\begin{array}{r}0.24 \\
.01 \\
8.17 \\
5.24 \\
4.33 \\
20.32 \\
61.41\end{array}$ \\
\hline $\begin{array}{l}\text { Co }{ }_{2} \text { needed } \ldots \ldots \ldots \ldots \ldots \ldots \ldots \ldots \ldots \ldots \ldots \\
\text { Organic matter, etc } \ldots \ldots \ldots \ldots \ldots \ldots \ldots \ldots \ldots\end{array}$ & $\begin{array}{r}99.19 \\
24.100 \\
3.23\end{array}$ & $\begin{array}{r}98.25 \\
34.9 . \\
6.04\end{array}$ & $\begin{array}{r}98.48 \\
34.46 \\
4.36\end{array}$ & 99.30 & 100.21 & $\begin{array}{r}99.72 \\
\ldots \ldots \\
\ldots \ldots\end{array}$ \\
\hline
\end{tabular}

Tests for fluorine failed to show its presence in any of these tubes.

These analyses fall into two distinct groups, one low in sulphates and phosphates, the other unusually high. The first three are easily reducible to standard form if we reject the insoluble matter, the silica, and the sesquioxides, which represent inclusions of sand or mud. The reduced analyses then assume the following form:

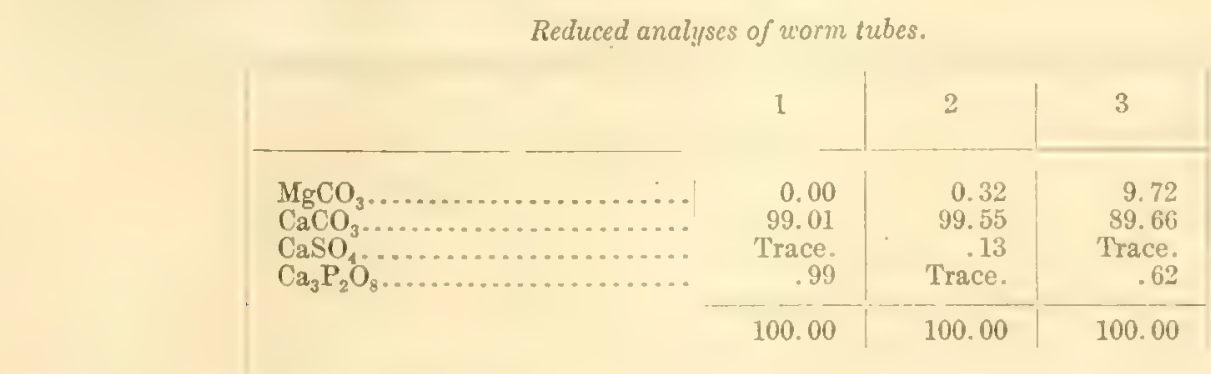

17 Lenoz, L. R., Harvard Coll. Mus. Comp. Zool. Bull., vol. 14, g., 201 , 1904. 
T'wo of these analyses resemble those of corals and mollusks; the third is more like one of an alcyonarian or an echinoderm. In all three the organic matter is very low. Three other partial analyses by Forchhammer ${ }^{19}$ are on record, which may be compared with these; although only magnesium carbonate was determined. These are--

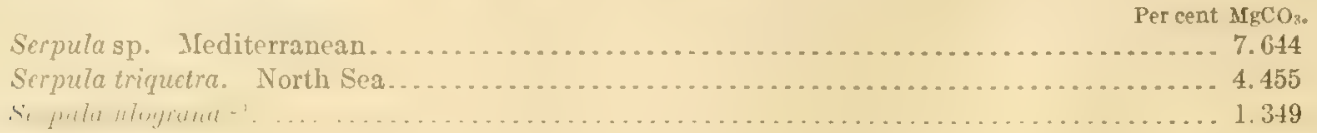

'The tubes of Serpula are evidently quite variable in composition, at least as regards their magnesian content.

'The tubes formed by Leodice and Hyalinccia, being highly phosphatic, are difficult to interpret chemically. The bases are insufficient to satisfy the acids if the phosphoric oxide is assumed to represent the normal tribasic salts. Phosphorus may be present as part of the organic matter, and so, too, may a portion of the sulphur. Metaphosphates, pyrophosphates, and acid orthophosphates are also possibly present, and between these alternatives it is not easy to decide. Acid salts are, howerer, improbable, for when boiled in water the tubes give faintly alkaline reactions. We prefer, therefore, to leave the reduction of analyses 4,5 , and 6 in abeyance until more eridence can be obtained. In this direction an analysis of Onuphis tubicola Müller, by Schmiedeberg, ${ }^{21}$ is suggestive. To the organic matter of the tube of Onuphis, "onuphin," he assigns the formula $\mathrm{C}_{24} \mathrm{H}_{43} \mathrm{NO}_{18}$, and the tube itself he regards as a complex compound of the composition

$$
\mathrm{C}_{24} \mathrm{H}_{43} \mathrm{NO}_{18}+\mathrm{CaHPO}_{4}+4 \mathrm{MgHPO}_{4}+22 \mathrm{H}_{2} \mathrm{O} \text {. }
$$

The analyses given by Schmiedeberg are as follows:

Analyses of Onuphis tubicola.

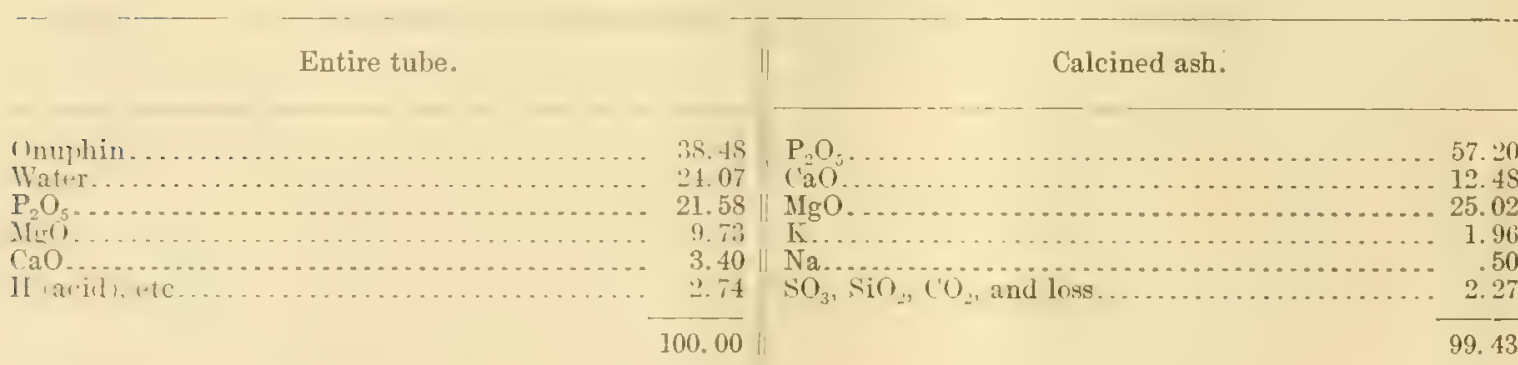

In a general way this analysis of Onuphis resembles our analysis of Hyalinacia, except that the magnesia is much higher and the sulphates, if present, are insignificant in amount. It will be noticed, moreover, that Schmiedeberg assumes the presence of acid phosphates in his interpretation of the data, which, as we have already stated, is improbable.

None of the analyses of the phosphatic worm tubes can be regarded as wholly satisfactory, but it is clear that these structures add phosphorus to the sediments. If they decay in contact with calcareous sediments, the final product would probably be a tribasic phosphate, and that is as far as we now need to go.

Forchhammer, G., Neues Jahrb., 1552, p. \$5.

zo In a later memoir (Philos. Trans., vol. 155, p. 203, 1S65) Forchhammer gires the percentage of $\mathrm{MgCO}_{3}$ in Serpula flograna as 13.49 per ceut. Which figure is correct?

2t schmiedeberg, 0., Zool. Sta. Naples Mitt., vol. 3, p. 373, 1882. 


\section{HCIINOIORMTS.}

\section{CRINOIDS.}

RRCENT CIRINOIDS.

In $1906 \mathrm{II} . \mathrm{W}$. Nichols ${ }^{22}$ published a number of partial analyses of marine invertebrates, and in a crinoid, Metacrinus rotundus from Japan, he found 11.72 per cent of magnesium carbonate. This analysis attracted the attention of Austin H. Clark, and at his request two other analyses of crinoids were made in the laboratory of the United States Geological Survey by Chase Palmer, who also found that they contained abundant magnesia. These analyses, which were published and discussed by Mr. Clark, ${ }^{23}$ will be considered in detail later. 'They at once suggested that crinoids generally might be highly magnesian and so play an important part in the formation of magnesian limestones.

In order to settle this question Mr. Clark supplied us with 24 specimens of recent crinoids, representing 21 genera and covering a wide range of localities. These were analyzed by Mr. Wheeler, and the analyses confirmed the original supposition. All the specimens contained magnesium carbonate in notable proportions but rarying in a most remarkable manner. 'The data obtained are in detail as follows, beginning with the list of the specimens studied:

1. Plitocinus pinnatus $\Lambda$. II. Clark. Albatross station 3342, of the Queen Charlotte Islands, British Columbia: latitude, $52^{\circ} 39^{\prime} 30^{\prime \prime} \mathrm{N}$.; longitude, $132^{\circ} 38^{\prime} \mathrm{W}$; ; depth of water, 2,858 meters; bottom temperature, $1.83^{\circ} \mathrm{C}$. Mean of two analyses.

2. Florometra asperrima Clark Albatross station 3070 , off the coast of Washington; latitude, $47^{\circ} 29^{\prime} 30^{\prime \prime} \mathrm{N}$. longitude, $125^{\circ} 43^{\prime} \mathrm{W}$; depth, 1,145 meters; bottom temperature, $3.28^{\circ} \mathrm{C}$

3. Psathyrometra fragilis Clark. Albatross station 5032, Yezo Strait, Japran; latitude, $44^{\circ} 05^{\prime} \mathrm{N} . ; 1$ longitude, $145^{\circ}$ $30^{\prime} \mathrm{E}$.; depth, 510-959 meters; bottom temperature, $1.61^{\circ} \mathrm{C}$.

4. Pentametrocrinus japonicus P. H. Carpenter. Albatross station 5083, 34.5 miles off Omai Saki Light, Japan; latitude, $34^{\circ} 04^{\prime} 20^{\prime \prime} \mathrm{N}$.; longitude, $137^{\circ} 57^{\prime} 30^{\prime \prime} \mathrm{E}$.; depth, 1, 123 meters; bottom temperature, $3.39^{\circ} \mathrm{C}$.

5. Capillaster muliradiata Linné. Albatross station 5137, Philippine Islands near Jolo, 1.3 miles from Jolo Light; latitude, $6^{\circ} 04^{\prime} 25^{\prime \prime} \mathrm{N}$; ; longitude, $120^{\circ} 58^{\prime} 30^{\prime \prime} \mathrm{E}$; depth, 36 meters; no temperature record.

6. Pachylometra patula Carpenter. Albatross station 5036, Philippine Islands, North Balabac Strait, 15.5 miles from Balabac light; latitude, $8^{\circ} 06^{\prime} 40^{\prime \prime} \mathrm{N}$.; longitude, $117^{\circ} 18^{\prime} 45^{\prime \prime} \mathrm{E}$.; depth, 104 meters; no temperature record.

7. Catoptometra ophiura Clark. Same locality as No. 6.

8. Hypalocrinus naresianus Carpenter. Albatross station 5424, Philippine Islands, 3.4 miles off Cagayan Island, Jolo Sea; latitude, $9^{\circ} 37^{\prime} 05^{\prime \prime} \mathrm{N}$.; longitude, $121^{\circ} 12^{\prime} 37^{\prime \prime} \mathrm{E}$.; depth. 612 meters; bottom temperature, $10.22^{\circ} \mathrm{C}$.

9. Parametra granulata Clark. Albatross station 5536, Philippine Islands, between Negros and Siquijor, 11: 8 miles from Apo Tsland; latitude, $9^{\circ} 15^{\prime} 45^{\prime \prime} \mathrm{N}$.; longitude, $123^{\circ} 22^{\prime} \mathrm{E}$.; depth, 502 meters; bottom temperature, $11.95^{\circ} \mathrm{C}$.

10. Craspedometra anceps Carpenter. Albatross station 5157, 3.3 miles from Tinakta Island, Tawi Tawi group, Sulu Archipelago; latitude, $5^{\circ} 12^{\prime} 30^{\prime \prime}$ N.; longitude, $119^{\circ} 55^{\prime} 50^{\prime \prime}$ E.; depth, 32 meters; no temperature record.

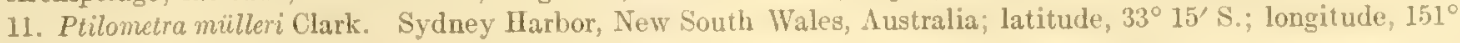
12 ' E., approximately.

12. Hathrometra dentata Say. Fish Hawk station 1033, off Marthas Vineyard, Mass.; latitude, 39 $56^{\prime}$ N.; longitude, $69^{\circ} 21^{\prime} \mathrm{W}$; ; depth, 329 meters; bottom temperature, about $7.8^{\circ} \mathrm{C}$.

13. Bythocrinus robustus Clark. Albatross station 2401, Gulf of Mexico, southeast of Pensacola; latitude, $28^{\circ} 38^{\prime} 30^{\prime \prime}$ N.; longitude, $85^{\circ} 52^{\prime} 30^{\prime \prime} \mathrm{W}$.; depth, 255 meters; no temperature record.

14. Crinometra concinna Clark. Albatross station 2321, north of Cuba; latitude, $23^{\circ} 10^{\prime} 35^{\prime \prime}$ N.; lungitude, $82^{\circ} 20^{\prime}$ $24^{\prime \prime} \mathrm{W}$; depth, 59 meters; bottom temperature. $26.17^{\circ} \mathrm{C}$

15. Isocrinus decorus WVyville Thomson, stem. Off Habana, Cuba; latitude, $24^{\circ} \mathrm{N}$; longitude, $82^{\circ} \mathrm{W}^{\prime}$; approximately.

16. Same as No. 15, arms.

17. Endoxocrinus parræ Gervais, stem. Off Habana, Cuba.

18. Same as No. 17, arms.

19. Tropiometra picta Gay. Rio de Janeiro, Brazil; latitude, $25^{\circ} 54^{\prime} \mathrm{S}$.; longitude, $44^{\circ} \mathrm{W}$., approximately

20. Promachocrinus kerguelensis Carpenter. Shores of the Antarctic Continent in the vicinity of Gaussberg; latitude, $67^{\circ} \mathrm{S}$; l longitude, $90^{\circ} \mathrm{E}$., approximately; depth, 350-100 meters; bottom temperature, $-1.85^{\circ} \mathrm{C}$; ; salinity of water, 3.3 per cent.

21. Anthometra adriani Bell. Same locality as No. 20. Nos, 20 and 21 were collected by the German South Polar Expedition.

22. Zygometra microdiscus Bell. Aru Islands, near the western point of New Guinea; latitude, $5^{\circ}-6^{\circ} \mathrm{S}^{\mathrm{S}}$.

23. Chlorometra 'rugosa Clark. Near Rotti, Lesser Sunda Islands; latitude, $10^{\circ} 39^{\prime} \mathrm{S}$.; longitude, $123^{\circ} 40^{\prime} \mathrm{E}$. depth, 520 meters.

22 Nichols, Ir. W., Field Columbian Mus. Pub. 111, p. 31, 1906.

2s Clark, A. H., U. S. Nat. Mus, P'ron., rol. 39, p. Ai, 1911. 
24. Tropiometra carinata, Lamarck. From Pigeon Point, Tobago, British West Indies. Shoal water, near shore temperature about $28^{\circ} \mathrm{C}$. Received from Dr. Hubert L. Clark. According to A. II. Clark it is probably T. picta Analysis by R. II. Kamm.

The actual analyses are giren in the table below. Sulphates were determined in only one of them, because the material was insufficient.

Analyses of crinoid skeletons.

\begin{tabular}{|c|c|c|c|c|c|c|}
\hline & 1 & 2 & 3 & 4 & 5 & 6 \\
\hline 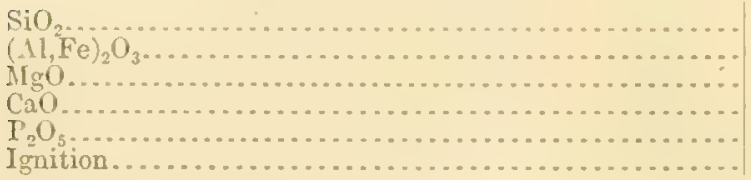 & $\begin{array}{r}1.64 \\
1.07 \\
3.08 \\
40.65 \\
.11 \\
51.45\end{array}$ & $\begin{array}{r}0.04 \\
.34 \\
3.60 \\
40.37 \\
53.21 \\
53\end{array}$ & $\begin{array}{r}1.11 \\
1.01 \\
3.12 \\
34.20 \\
\text { Trace? } \\
60.04\end{array}$ & $\begin{array}{r}0.37 \\
.71 \\
3.76 \\
38.50 \\
55.25\end{array}$ & $\begin{array}{r}0.16 \\
.62 \\
4.77 \\
38.12 \\
\text { Trace. } \\
54.61\end{array}$ & $\begin{array}{r}0.12 \\
.63 \\
4.94 \\
41.34 \\
.43 \\
51.30\end{array}$ \\
\hline $\begin{array}{l}\mathrm{CO}_{2} \text { needed................ } \\
\text { Organic matter, etc....... }\end{array}$ & $\begin{array}{l}98.00 \\
35.23 \\
16.22\end{array}$ & $\begin{array}{l}98.36 \\
35.48 \\
18.27\end{array}$ & $\begin{array}{l}99.48 \\
31.37 \\
28.67\end{array}$ & $\begin{array}{l}98.99 \\
34.01 \\
21.24\end{array}$ & $\begin{array}{l}98.28 \\
35.19 \\
19.42\end{array}$ & $\begin{array}{l}98.82 \\
37.51 \\
13.85\end{array}$ \\
\hline
\end{tabular}

\begin{tabular}{|c|c|c|c|c|c|c|}
\hline & 7 & 8 & 9 & 10 & 11 & 12 \\
\hline \multirow[t]{2}{*}{ 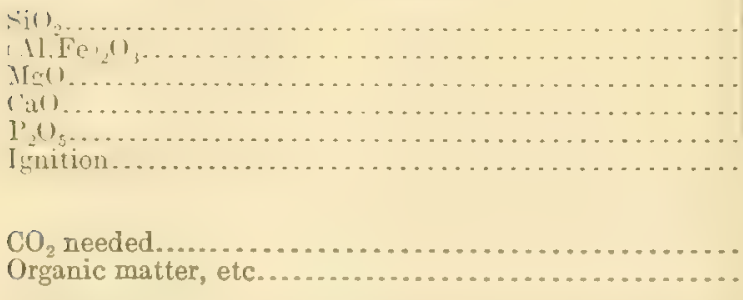 } & $\begin{array}{r}0.04 \\
.79 \\
4.64 \\
40.75 \\
.33 \\
51.80\end{array}$ & \begin{tabular}{r|}
0.07 \\
.09 \\
4.44 \\
45.86 \\
Trace. \\
48.32
\end{tabular} & $\begin{array}{r}0.40 \\
.50 \\
4.48 \\
41.79 \\
\text { Trace. } \\
51.44\end{array}$ & $\begin{array}{r}0.15 \\
.19 \\
5.13 \\
42.77 \\
50.11\end{array}$ & $\begin{array}{r}0.17 \\
.19 \\
4.17 \\
38.91 \\
.17 \\
54.61\end{array}$ & $\begin{array}{r}3.17 \\
.31 \\
2.49 \\
26.12 \\
65.23\end{array}$ \\
\hline & $\begin{array}{l}98.35 \\
36.81 \\
14.99\end{array}$ & $\begin{array}{r}98.78 \\
41.27 \\
7.05\end{array}$ & $\begin{array}{l}98.61 \\
37.77 \\
13.67\end{array}$ & $\begin{array}{l}98.63 \\
39.17 \\
11.11\end{array}$ & $\begin{array}{l}98.22 \\
34.90 \\
19.71\end{array}$ & $\begin{array}{l}97.57 \\
22.73 \\
42.52\end{array}$ \\
\hline & 13 & 14 & 15 & 16 & 17 & 18 \\
\hline 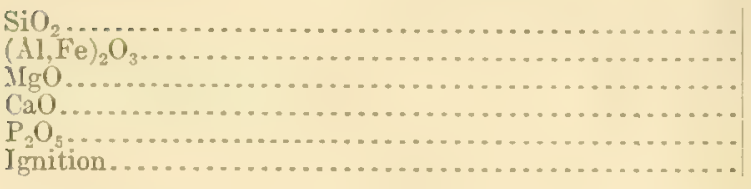 & $\begin{array}{r}0.40 \\
.31 \\
4.56 \\
47.08 \\
\text { Trace. } \\
47.17\end{array}$ & $\begin{array}{r}0.04 \\
.25 \\
4.75 \\
41.78 \\
\text { Trace. } \\
50.33\end{array}$ & $\begin{array}{r}0.03 \\
.07 \\
5.08 \\
45.67 \\
\text { Trace. } \\
47.54\end{array}$ & $\begin{array}{r}0.09 \\
.19 \\
4.70 \\
42.77 \\
\text { Trace? } \\
50.59\end{array}$ & $\begin{array}{r}0.04 \\
.20 \\
5.09 \\
45.42 \\
\text { Trace. } \\
48.58\end{array}$ & $\begin{array}{r}0.15 \\
.26 \\
5.04 \\
43.41 \\
\text { Trace. } \\
50.00\end{array}$ \\
\hline 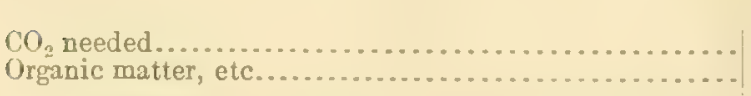 & $\begin{array}{r}99.52 \\
41.93 \\
5.24\end{array}$ & $\begin{array}{l}97.15 \\
38.00 \\
12.33\end{array}$ & $\begin{array}{r}98.39 \\
40.40 \\
7.14\end{array}$ & $\begin{array}{l}98.34 \\
38.71 \\
11.88\end{array}$ & $\begin{array}{r}99.33 \\
41.29 \\
7.29\end{array}$ & $\begin{array}{l}98.86 \\
39.65 \\
10.35\end{array}$ \\
\hline & 19 & 20 & 21 & 22 & 23 & 24 \\
\hline 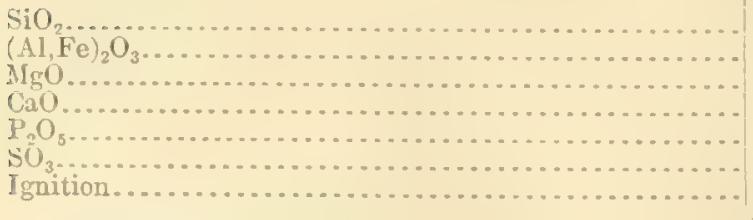 & $\begin{array}{r}0.02 \\
.35 \\
4.51 \\
39.57 \\
.10 \\
(? 3) \\
53.64\end{array}$ & $\begin{array}{r}0.02 \\
.45 \\
3.02 \\
40.68 \\
\text { Trace. } \\
\text { (?) } \\
54.53\end{array}$ & $\begin{array}{r}0.23 \\
.37 \\
3.27 \\
42.49 \\
\text { Trace. } \\
\text { (?) } \\
52.22\end{array}$ & $\begin{array}{r}0.04 \\
.48 \\
4.92 \\
37.19 \\
.17 \\
(?) \\
55.05\end{array}$ & $\begin{array}{r}0.05 \\
.23 \\
3.99 \\
42.72 \\
\text { Trace. } \\
\text { (?) } \\
51.69\end{array}$ & $\begin{array}{r}0.40 \\
.38 \\
4.87 \\
35.35 \\
.22 \\
.63 \\
56.14\end{array}$ \\
\hline 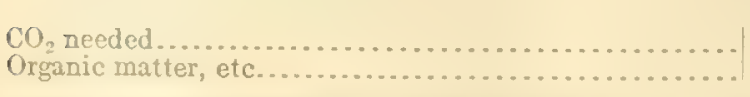 & $\begin{array}{l}98.19 \\
36.05 \\
17.59\end{array}$ & $\begin{array}{l}98.70 \\
35.18 \\
19.35\end{array}$ & $\begin{array}{l}98.58 \\
37.08 \\
15.14\end{array}$ & $\begin{array}{l}97.85 \\
34.47 \\
20.58\end{array}$ & $\begin{array}{l}98.68 \\
37.95 \\
13.74\end{array}$ & $\begin{array}{l}97.99 \\
32.58 \\
23.56\end{array}$ \\
\hline
\end{tabular}

The summation in most of these analyses is low. The deficiency is due mainly to inclosed or adherent sea salts, an inevitable impurity, as was proved in the analyses of two separate samples. In No. 15, 1.27 per cent of water-soluble salts was found, and in No. 17, 0.21 per cent. These additions raise the summations to 99.66 and 99.54 per cent, respectively. 
The reduced analyses are as follows, rejecting organic matter and water and recalculating to 100 per cent:

Reduced analyses of crinoid skeletons.

\begin{tabular}{|c|c|c|c|c|c|c|}
\hline- & 1 & 2 & 3 & 4 & 5 & 6 \\
\hline \multirow[t]{2}{*}{ 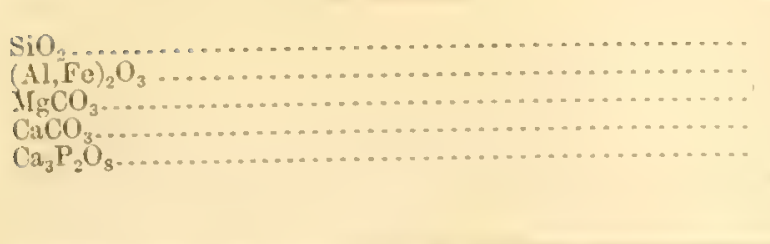 } & $\begin{array}{r}2.01 \\
1.31 \\
7.91 \\
\text { S5. } 45 \\
.29\end{array}$ & $\begin{array}{r}0.03 \\
.48 \\
9.44 \\
89.45 \\
.58\end{array}$ & $\begin{array}{r}1.57 \\
1.41 \\
9.25 \\
\text { S7. } \\
\text { Trace? }\end{array}$ & $\begin{array}{r}0.48 \\
.91 \\
10.15 \\
87.34 \\
1.12\end{array}$ & $\begin{array}{r}0.21 \\
12.69 \\
86.32 \\
\text { Trace. }\end{array}$ & $\begin{array}{r}0.14 \\
12.24 \\
85.81 \\
1.11\end{array}$ \\
\hline & 100.00 & 100.00 & 100.00 & 100.00 & 100.00 & 100.00 \\
\hline \multirow{3}{*}{ 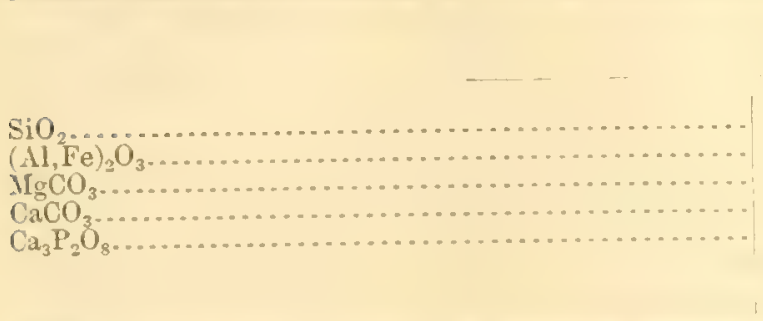 } & 7 & 8 & 9 & 10 & 11 & 12 \\
\hline & $\begin{array}{r}0.05 \\
.95 \\
11.65 \\
56.46 \\
.86 \\
\end{array}$ & $\begin{array}{r}0.05 \\
.10 \\
10.16 \\
89.66 \\
\text { Trace. }\end{array}$ & $\begin{array}{r}0.47 \\
.59 \\
11.08 \\
97.56 \\
\text { Trace. }\end{array}$ & $\begin{array}{r}0.24 \\
.22 \\
12.34 \\
56.93 \\
.27\end{array}$ & $\begin{array}{r}0.21 \\
.24 \\
11.13 \\
87.94 \\
.48\end{array}$ & $\begin{array}{r}5.73 \\
.56 \\
9.36 \\
83.47 \\
.85\end{array}$ \\
\hline & 100.00 & 100.00 & 100.00 & 100:00 & 100.00 & 100.00 \\
\hline \multirow{3}{*}{ 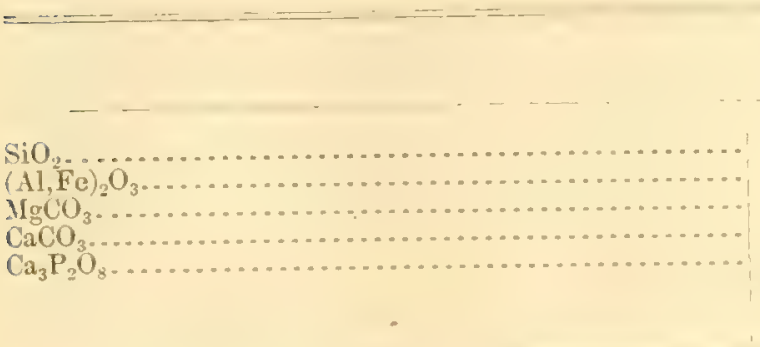 } & 13 & 14 & 15 & 16 & 17 & 18 \\
\hline & $\begin{array}{r}0.42 \\
.33 \\
10.09 \\
87.16 \\
\text { Trace. }\end{array}$ & $\begin{array}{r}0.05 \\
.30 \\
11.69 \\
87.96 \\
\text { Trace. }\end{array}$ & $\begin{array}{r}0.03 \\
.08 \\
11.69 \\
58.20 \\
\text { Trace. }\end{array}$ & $\begin{array}{r}0.10 \\
.21 \\
11.42 \\
88.27 \\
\text { Trace. }\end{array}$ & $\begin{array}{r}0.04 \\
.21 \\
11.62 \\
88.13 \\
\text { Trace. }\end{array}$ & $\begin{array}{r}0.17 \\
.29 \\
11.96 \\
87.55 \\
\text { Trace. }\end{array}$ \\
\hline & 100.00 & 100.00 & 100.00 & 100.00 & 100.00 & 100.00 \\
\hline \multirow{3}{*}{ 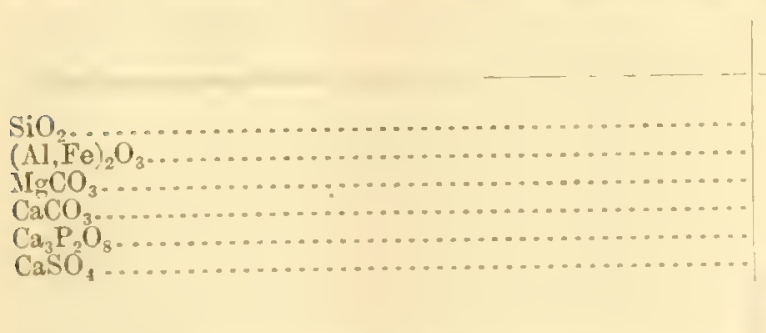 } & 19 & 20 & 21 & 22 & 23 & 24 \\
\hline & $\begin{array}{r}0.02 \\
.43 \\
11.77 \\
87.51 \\
(? .27\end{array}$ & $\begin{array}{l}0.02 \\
7.57 \\
7.56 \\
91.55 \\
\text { Trace. } \\
\text { (?) }\end{array}$ & $\begin{array}{r}0.28 \\
.44 \\
8.23 \\
91.05 \\
\text { Trace. } \\
(?)\end{array}$ & $\begin{array}{r}0.05 \\
.62 \\
13.37 \\
85.48 \\
(?)^{48}\end{array}$ & $\begin{array}{r}0.06 \\
.27 \\
9.87 \\
89.80 \\
\text { Trace. } \\
\text { (?) }\end{array}$ & $\begin{array}{r}0.54 \\
.21 \\
13.74 \\
83.13 \\
.64 \\
1.44\end{array}$ \\
\hline & 100.00 & 100.00 & 100.00 & 100.00 & 100.00 & 100.0 \\
\hline
\end{tabular}

With these analyses the two made by Mr. Palmer may be adrantageously compared, although they were not quite so elaborate. The data are as follows:

25. Heliometra glacialis var. maxima. Iwanai Bay, northeastern part of the Sea of Japan; latitude. $43^{\circ} 01^{\prime} 40^{\prime \prime} \mathrm{N}$. ; depth, 315 meters; temperature, surface, $20.5^{\circ} \mathrm{C}$, bottom, $1.5^{\circ} \mathrm{C}$.

26. Metacrinus rotundus. Eastern Sea, off Kagoshima Gulf, southern Japan; latitude, $30^{\circ} 58^{\prime} 30^{\prime \prime} \mathrm{N} . ;$ depth, 278 meters; temperature, surface, $27.8^{\circ} \mathrm{C}$, bottom, $13.3^{\circ} \mathrm{C}$.

In No. 24, which contained much organic matter, Mr. Palmer found 2.68 per cent $\mathrm{MgO}$

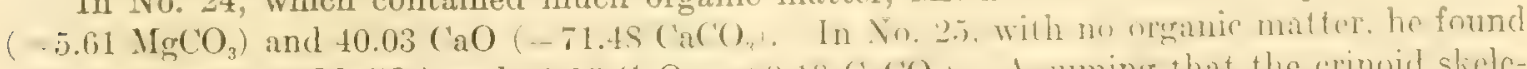

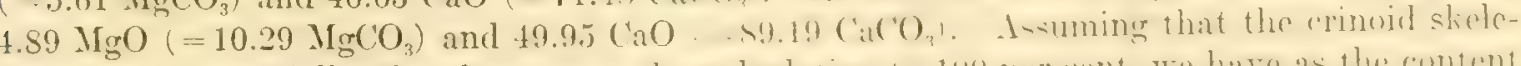
tons consist essentially of carbonates, and recialeulating to lout pere rent. We hate as the content of magnesium carbonate in these crinoids- 
These figures fit in well with the others and even by themselves suggest a relation between temperature and the magnesia content of crinoids. In the following table the entire series is arranged in the order of ascending magnesium carbonate, with the accessory data as to latitude and locality abbreriated. In this table the two analyses of Endoxocrinus are averaged together, and so also are the two of 7 socrinus.

Perentage of magnesium curbonate in crinoids.

Genus.

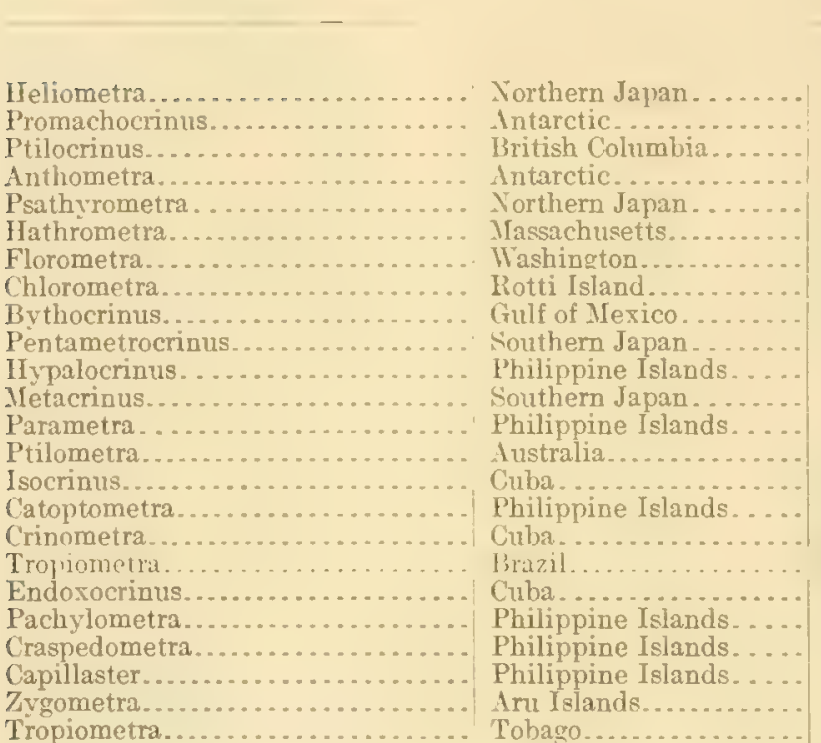

Latitude.

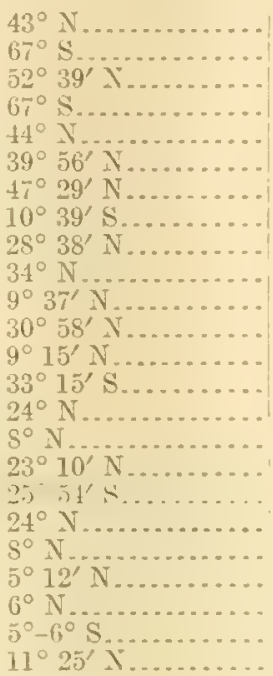

\begin{tabular}{|c|c|c|}
\hline 1)epth. & $\begin{array}{c}\text { Temper- } \\
\text { ature. }\end{array}$ & $\mathrm{MgCO}$. \\
\hline $\begin{array}{c}\text { Teters. } \\
315 \\
375 \\
2,858 \\
375 \\
375 \\
(?) \\
329 \\
1,145 \\
520 \\
255 \\
1,123 \\
612 \\
278 \\
502 \\
(?) \\
(?) \\
104 \\
59 \\
?, \\
(?) \\
1,044 \\
32 \\
36 \\
(?)\end{array}$ & $\begin{array}{r}{ }^{\circ} C \\
1.5 \\
-1.5 \\
1.8 \\
-1.8 \\
1.6 \\
7.8 \\
3.3 \\
(?) \\
(?) \\
3.4 \\
10.2 \\
13.3 \\
12 \\
(?) \\
(?) \\
(?) \\
26.2 \\
? 1 \\
(?) \\
(?) \\
(?) \\
(?) \\
(?) \\
25\end{array}$ & $\begin{array}{r}\text { Per cent. } \\
7.2 \\
7.5 \\
7.9 \\
8.2 \\
9.2 \\
9.3 \\
9.4 \\
9.8 \\
10.0 \\
10.1 \\
10.1 \\
10.3 \\
11.0 \\
11.1 \\
11.5 \\
11.6 \\
11.6 \\
11.7 \\
11.7 \\
12.2 \\
12.3 \\
12.6 \\
13.3 \\
13.7\end{array}$ \\
\hline
\end{tabular}

The percentage of magnesium carbonate in Chlorometra is low for the latitude of the locality, but that is doubtless due to the depth of the water (520 meters) in which the crinoid lired. The probable temperature at that depth was between $7^{\circ}$ and $10^{\circ} \mathrm{C}$.

From the foregoing table it is perfectly clear that the proportion of magnesium carbonate in erinoids is in some way dependent on temperature. Temperature, horever, is not entirely dependent on latitude. Depth of water has also a distinct influence. The crinoids from relatively shallow depths in the Tropics are highest in their magnesium content; those from the Antarctic and the far north are lowest. The proportion given for No. 12, from the coast of Massachusetts, is probably too low, for the specimen as analyzed contained over 6 per cent of silica and sesquioxides-erident impurities, due to adherent mud from which the delicate structure could not be wholly freed. If these are rejected, the magnesium carbonate is raised from 9.36 to 10 per cent, which gires the crinoid a better and more probable rating.

So far as we are aware such a peculiar relation between temperature and composition as is here recorded has not been preriously observed. To recognize it is one thing; to account for it is not so easy. It first we supposed that it might possibly be due to a difference in the form of the more abundant carbonate-the less stable aragonite in the warm-water forms and calcite in the crinoids from colder regions. But tests by Meigen's renction prored that the organisms were all calcitic, and so this supposition had to be abandoned.

Mr. A. H. Clark, who is an authority on the crinoids, informs us that those from warm recgions have the most compact skeletons, the compactness being in general proportional to the temperature and to some extent dependent upon the size of the individual. Hetiometra, for example, is the largest of the crinoids, its skeleton is one of the least compact, and its magnesian content is lowest among all the species examined. Structure as well as temperature 
seems to be correlated with the proportion of magnesia in the crinoids, but the chemical explanation of the facts is yet to be found. It may have connection with the gaseous conterit of sea water, carbon dioxide, for example, being more soluble in warm than in cold waters, but this is only a suggestion, which may or may not be fruitful. 'The same regularity as to temperature also appears in our analyses of alcyonarians.

\section{FOSSIL, CRINOIDS.}

In order to make this investigation more systematic it scemed desirable to analyze a number of fossil crinoids, so as to determine whether any definite and regular changes could be traced in passing from the recent to the ancient organisms. For the material studied we are indebted to the kindness of Mr. Frank Springer, who selected the material with great care so as to cover a range of horizons from the Lower Ordorician up to the Eocene. 'The 10 crinoids chosen are described in the list below, and the nnalyses which follow were marle in the same way as those of the modern species:

1. Pentacrinus dccadactylus Dorbigny, stem. Eorene, Vincenzil, li:ly.

2. Millericrims nespiliformis Goldfuss, stem. Cpper Jumsic, Kelheim, liararia.

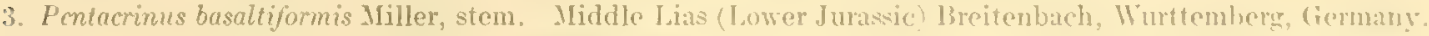

4. Encrinus liliformis Lamarck, stem. Triassic. Braunschweig, Germany.

5. Graphiocrinus magnificus Miller and Gurley, complete crown. Pennsylvanian (upper ('urboniferous), Kanw:s ('ity, IIo.

6. Dorycrimus unicornis (Jen and Shumard. calyx and stem. Lower part of Hurlington limestone, Mississippian (lower Carboniferous), Burlington, lowa.

7. Megistocrimus nodosus Barris, plates. Middle Devonian, Alpena, Mich.

8. Eucrlyptocrimus crussius, plates. Silurian, western Tennessee.

9. ('rinoid sp.?, stem. Trenton limestone, Middle Ordovician, Kirklickl, ('unuda.

II). Dirbolnerinus vesporalis White, plates and stem. Lower ()rdovician, fennessee.

Inalyses of fossil crinoids.

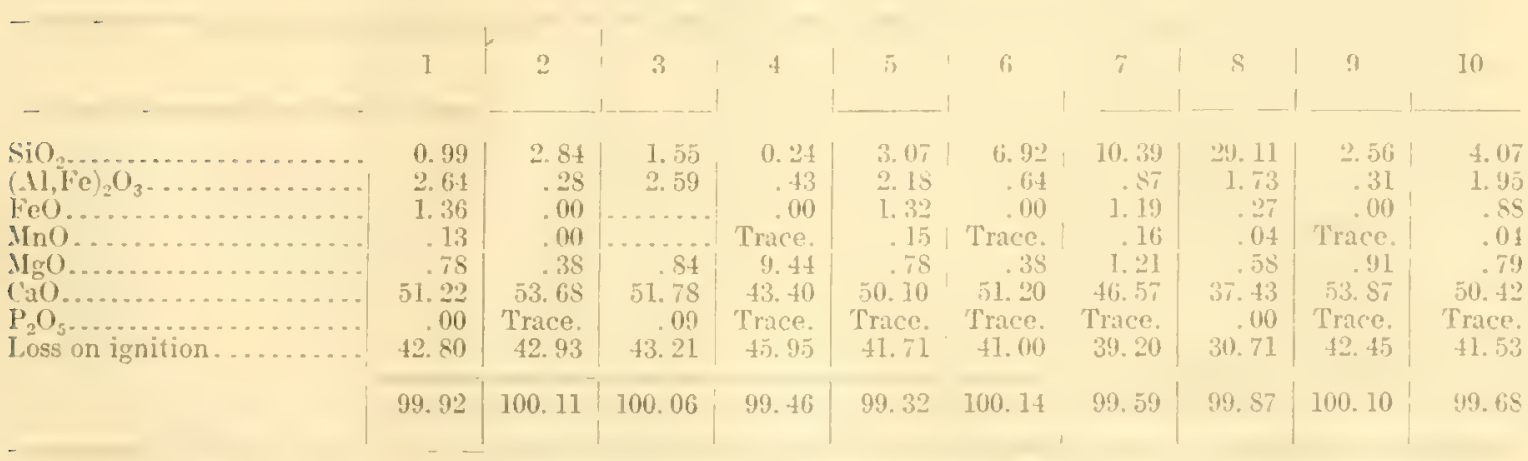

Reduced analyses of jossil crinoids.

\begin{tabular}{|c|c|c|c|c|c|c|c|c|c|c|}
\hline & 1 & 2 & 3 & 4 & 5 & 6 & $i$ & \& & 9 & 10 \\
\hline 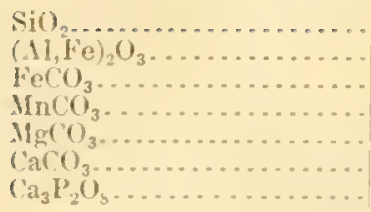 & $\begin{array}{r}1.00 \\
2.66 \\
2.21 \\
.21 \\
1.66 \\
32.26 \\
.00\end{array}$ & $\begin{array}{r}2.85 \\
.28 \\
.00 \\
.00 \\
.80 \\
96.07 \\
\text { Trace. }\end{array}$ & \begin{tabular}{r}
1.57 \\
2.64 \\
$\cdots . .$. \\
\hdashline .79 \\
1.79 \\
93.80 \\
.20
\end{tabular} & $\begin{array}{r}0.24 \\
.41 \\
.00 \\
\text { Trace } \\
20.23 \\
79.09 \\
7 r a c e .\end{array}$ & $\begin{array}{r}\text { 3. } 11 \\
2.23 \\
2.16 \\
.24 \\
\text { 1. } 16 ; \\
\text { 90. } 1 \text { il } \\
\text { Trace. }\end{array}$ & $\begin{array}{r}6.94 \\
.64 \\
.00 \\
\text { Trice. } \\
.80 \\
91.62 \\
\text { Trace. }\end{array}$ & $\begin{array}{r}\text { 10. } 48 \\
.85 \\
1.414 \\
.267 \\
2.56 \\
\text { s.3. } 85 \\
\text { Trace. }\end{array}$ & $\begin{array}{r}29.30 \\
1.71 \\
.43 \\
.06 \\
1.23 \\
66.24 \\
.00\end{array}$ & $\begin{array}{r}2.55 \\
.20 \\
.00 \\
\text { Tritee. } \\
1.90 \\
95.25 \\
\text { Triace. }\end{array}$ & $\begin{array}{l}\text { 1. } 10 \\
1.97 \\
1.52 \\
.06 \\
1.67 \\
90.75 \\
\text { Trace. }\end{array}$ \\
\hline & 100.00 & 100.00 & 100.00 & 100.00 & 100.00 & 100.00 & 100.00 & 100.00 & 100.00 & 100.00 \\
\hline
\end{tabular}


In some respects these analyses are unsatisfactory, for they show no regularities of any kind. In only one of them, $\mathrm{No}$. 4, is there exhibited a concentration of magnesium carbonate; in the others the percentage of this constituent is very low. The reason for this decrease of magnesia is by no means clear. It is conceirable that the ancient crinoids may have been deficient in malcresia, hut it is more probable that the loss is due to alteration, perhaps to the infiltration of calcium carbonate. Such a change would obviously lower the apparent proportion of magnesium carbonate. Sereral of the crinoids contain noteworthy quantities of ferrous carbonate and manganese-constituents which did not appear in the analyses of the modern species. In No. $S$ there is a rery strong silicification, 29.11 per cent; but the matrix of the specimen contained only 7.55 per cent of silica. Here the infiltration of the impurity seems to be very clear. Some of the deficiencies in magnesia may have been caused by solution and leaching, but calcium carbonate should then have been remored to a greater extent. In short, the fossil crinuds differ widely in composition from the still living species, and in a rery irregular manner, and it is worth noting that in three analyses of fossil algæ reported by Högbom ${ }^{24}$ a similar decrease of magnesia appears. It would be easy to speculate on the significance of these differences, but the conclusions so reached would not be entitled to much weight. That the recent crinoids are distinctly magnesian and that the proportion of magnesia is dependent in some way on temperature are two positive results of this incestigation.

\section{SEA URCHINS.}

Twelve sea urchins selected for us by Mr. Austin H. Clark and two received from Dr. Hubert L. Clark were analyzed. The species chosen were as follows:

1. Strongylocmtrotus dröbachiensis O. F. Müller. Upernivik, Greenland; latitude $72^{\circ} 48^{\prime} \mathrm{N}$.

2. Strongylocentrotus fragilis Jackson. Albatross station 2946, off southern California; latitude, $33^{\circ} 5 S^{\prime} 00^{\prime \prime} \mathrm{N}$.; longitude, $119^{\circ} 30^{\prime} 45^{\prime \prime} \mathrm{W}$.; depth of water, 274.5 meters; bottom temperature, $13.6^{\circ} \mathrm{C}$.

3. Echinarachius parma Lamarck. Coast of New England.

4. Encope californica Terrill. Galapagos Islands, on or near the Equator.

5. Lytechinus anamesus H. I. Clark. Albatross station '2938, off Wilmington, Calif.; latitude, $33^{\circ} 35^{\prime} 15^{\prime \prime} \mathrm{N}$.; longitude, $115^{\circ} 0 S^{\prime} 30^{\prime \prime} \mathrm{W}$; d depth, 86 meters; bottom temperature, $15^{\circ} \mathrm{C}^{\prime}$

6. Loxcchinus albus Molina. Port Otway, Patagonia; latitude, about $46^{\circ}$ or $47^{\circ} \mathrm{S}$.

7. Tetrapygus niger Molina. Coast of Peru.

8. Tretocidaris alfin is Philippi. Albatross stations 2316 and 2317 , off Key West, Fla.; latitude, $24^{\circ} 25^{\prime}$ N.; longiiude, $81^{\circ} 47^{\prime} \mathrm{W}$; depth, 85 meters; bottom temperature, $24^{\circ} \mathrm{C}$.

9. Heterocentrotus mammillatus Linné. Low or Tuamotu Archipelago, southern Pacific Ocean; latitude, between $14^{\circ}$ and $24^{\circ} \mathrm{S}$.

10. Encope micropora A. Igassiz. Puerto Viejo, Ifargarita Bay; Lower California; latitude, $24^{\circ} 30^{\prime}$ N.; longitude, $112^{\circ} \mathrm{W}$., approximately.

11. Clypeaster testurlinarius Gray. Southern Japan:

12. Echinus affinis Mortensen. Albatross station 2206, between Hatteras and Nantucket; latitude, $39^{\circ} 35^{\prime} \mathbf{N}$; longitude, $71^{\circ} 34^{\prime} 30^{\prime \prime} \mathrm{W}$.; depth, 1,919 meters; bottom temperature, $3.6^{\circ} \mathrm{C}$.

Inalyses 10-12 by B. Salkover.

13. Echinomctra lucunter Linné. Pigeon Point, 'Tobago, British West Indies; latitude, $11^{\circ} 25^{\prime} \mathrm{N}$.; shoal water, near shore; temperature, $2 S^{\circ} \mathrm{C}$.

14. Mellita sexiesperjoratus Leske. Pigeon Point, Tobago, British West Indies; latitude, $11^{\circ} 25^{\prime}$ N.; shoal water, near shore; temperature, $28^{\circ} \mathrm{C}$.

Analyses 13 and 14 by R, M. Kamm.

21 Högbom, 1. G., Neues Jahrb., 1594, Band 1, p. 252. 
Analyses of sca urchins.

\begin{tabular}{|c|c|c|c|c|c|c|}
\hline & 1 & 2 & 3 & 4 & 5 & 6; \\
\hline 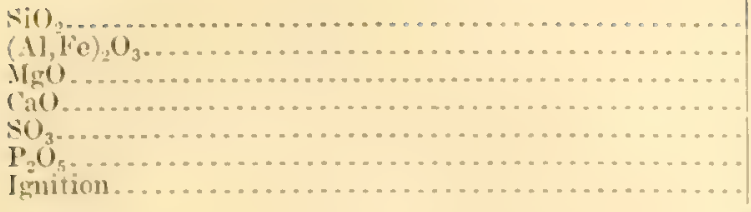 & $\begin{array}{r}0.12 \\
.34 \\
2.58 \\
17.34 \\
. .20 \\
\text { Trace. } \\
48.53\end{array}$ & $\begin{array}{r}0.26 \\
.65 \\
3.68 \\
41.08 \\
1.15 \\
52.39 \\
52.21\end{array}$ & $\begin{array}{r}0.14 \\
.27 \\
2.97 \\
49.17 \\
.36 \\
.05 \\
45.74\end{array}$ & $\begin{array}{r}3.86 \\
5.03 \\
4.75 \\
43.42 \\
.28 \\
\text { Trace. } \\
43.01\end{array}$ & $\begin{array}{r}8.52 \\
3.01 \\
3.04 \\
37.92 \\
.37 \\
.19 \\
45.38\end{array}$ & $\begin{array}{r}0.05 \\
.17 \\
3.07 \\
45.87 \\
.35 \\
\text { Trace. } \\
49.47\end{array}$ \\
\hline 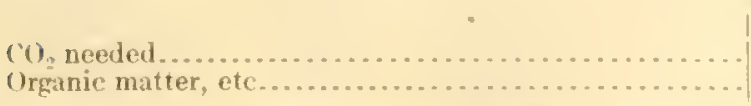 & $\begin{array}{r}99.11 \\
39.92 \\
8.61\end{array}$ & $\begin{array}{l}99.42 \\
34.20 \\
18.01\end{array}$ & $\begin{array}{r}98.60 \\
41.71 \\
4.03\end{array}$ & $\begin{array}{r}99.35 \\
38.99 \\
4.02\end{array}$ & $\begin{array}{l}98.43 \\
32.28 \\
13.10\end{array}$ & $\begin{array}{l}98.98 \\
39.34 \\
10.13\end{array}$ \\
\hline & 7 & 10 & 11 & 12 & 13 & 14 \\
\hline 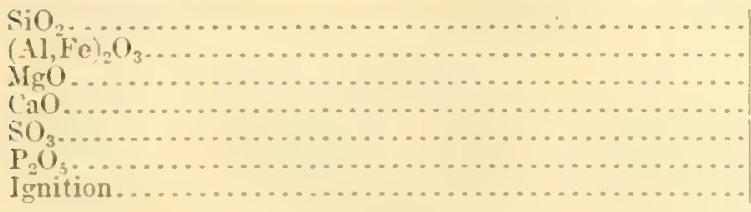 & $\begin{array}{r}0.31 \\
.30 \\
2.92 \\
48.86 \\
1.43 \\
\text { Trace. } \\
44.98\end{array}$ & $\begin{array}{r}2.38 \\
.81 \\
5.45 \\
38.24 \\
\text { Trace. } \\
\text { Trace. } \\
51.24\end{array}$ & $\begin{array}{r}0.15 \\
\text { 3. } 13 \\
49.73 \\
\text { Trace. } \\
\text { Trace. } \\
45.47\end{array}$ & $\begin{array}{r}\text { 3. } 01 \\
2.21 \\
2.39 \\
46.19 \\
\text { Trace. } \\
\text { Trace. } \\
46.90\end{array}$ & $\begin{array}{r}0.10 \\
.29 \\
4.16 \\
36.97 \\
.99 \\
.64 \\
51.82\end{array}$ & $\begin{array}{r}0.14 \\
.36 \\
5.23 \\
44.84 \\
1.37 \\
\text { Trace. } \\
46.70\end{array}$ \\
\hline 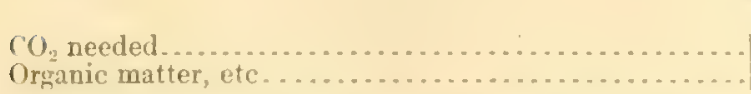 & $\begin{array}{r}98.70 \\
40.69 \\
\text { 4. } 29\end{array}$ & $\begin{array}{l}98.12 \\
36.64 \\
14.60\end{array}$ & $\begin{array}{r}99.38 \\
43.36 \\
2.11\end{array}$ & $\begin{array}{r}100.70 \\
38.92 \\
7.98\end{array}$ & $\begin{array}{l}94.96 \\
32.49 \\
19.33\end{array}$ & $\begin{array}{r}98.64 \\
39.27 \\
7.43\end{array}$ \\
\hline
\end{tabular}
form:

Rejecting the very variable organic matter, etc, the reduced analyses assume the following Reduced analyses of sea urchins.

\begin{tabular}{|c|c|c|c|c|c|c|}
\hline & 1 & 2 & 3 & 4 & 5 & 6 \\
\hline \multirow[t]{3}{*}{ 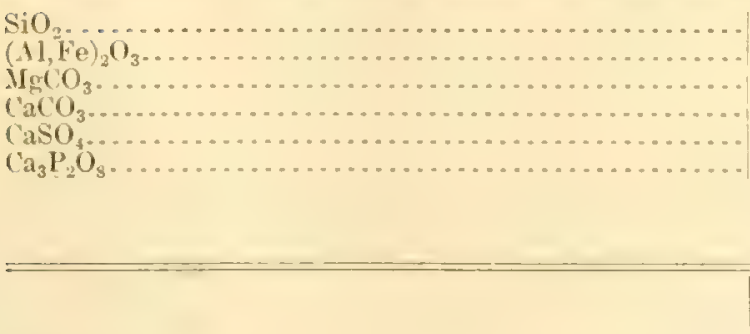 } & $\begin{array}{r}0.13 \\
.37 \\
5.99 \\
93.13 \\
.38 \\
\text { Trace. }\end{array}$ & $\begin{array}{r}0.32 \\
.81 \\
6.95 \\
83.44 \\
2.12 \\
1.06\end{array}$ & $\begin{array}{r}0.15 \\
.29 \\
6.59 \\
92.39 \\
.46 \\
.12\end{array}$ & $\begin{array}{r}3.99 \\
5.20 \\
10.38 \\
79.94 \\
.49 \\
\text { Trace. }\end{array}$ & $\begin{array}{r}9.93 \\
3.51 \\
7.44 \\
7.91 \\
.73 \\
.48\end{array}$ & $\begin{array}{r}0.05 \\
.18 \\
7.38 \\
91.73 \\
.66 \\
\text { Trace. }\end{array}$ \\
\hline & 100.00 & 100.00 & 100.00 & 100.00 & 100.00 & 100.00 \\
\hline & 7 & 10 & 11 & 12 & 13 & 14 \\
\hline \multirow[t]{2}{*}{ 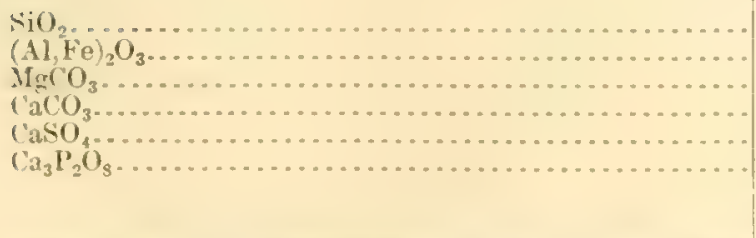 } & $\begin{array}{r}0.33 \\
.32 \\
6.27 \\
90.52 \\
2.56 \\
\text { Trace. }\end{array}$ & $\begin{array}{r}2.87 \\
.98 \\
13.79 \\
82.36 \\
\text { Trace. } \\
\text { Trace. }\end{array}$ & $\begin{array}{r}0.16 \\
.14 \\
8.41 \\
91.29 \\
\text { Trace. } \\
\text { Trace. }\end{array}$ & $\begin{array}{r}3.25 \\
2.38 \\
5.41 \\
88.96 \\
\text { Trace. } \\
\text { Trace. }\end{array}$ & $\begin{array}{r}0.13 \\
.37 \\
11.56 \\
83.87 \\
2.22 \\
1.85\end{array}$ & $\begin{array}{r}0.15 \\
.39 \\
11.91 \\
85.02 \\
2.53 \\
\text { Trace. }\end{array}$ \\
\hline & 100.00 & 100.00 & 100.00 & 100.00 & 100.00 & 100.00 \\
\hline
\end{tabular}

Sea urchins Nos. 8 and 9. Trefociduris and IIterocentrotus, must be considered separately from the others. No.9, a giant form, was the subject of four analyses, the shell or test, the dental pyramid, the small white spines on the border of the peristome, and the large purplishred spine. The large red spine analyzed was 15 centimeters long and weighed 13 grams. 
Analyses of Heterocentrotus mammillatus.

\begin{tabular}{|c|c|c|c|c|}
\hline & \multirow{3}{*}{ shell. } & \\
\hline \multirow{8}{*}{ 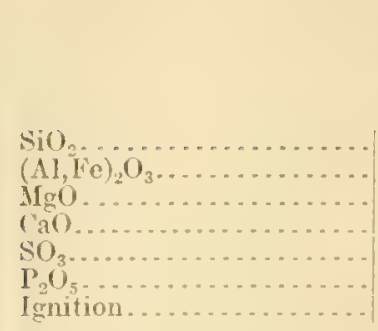 } & & $\begin{array}{c}\text { Dental ! } \\
\text { pyramid. }\end{array}$ & $\begin{array}{l}\text { White } \\
\text { spines. }\end{array}$ & $\begin{array}{l}\text { Red } \\
\text { spines. }\end{array}$ \\
\hline & & & . & \\
\hline & 0.02 & 0.02 & 0.05 & 0.05 \\
\hline & .13 & .08 & .13 & $.26 j$ \\
\hline & 5. 21 & 5. 50 & 3.74 & 4. 47 \\
\hline & 13.60 & $+1 i .02$ & +8. 26 & 47.72 \\
\hline & .61 & .58 & .29 & .75 \\
\hline & Trace. & Trace. & Trace, & Trace. \\
\hline & 99. 1.9 & 99. 20 & 98.93 & 99.27 \\
\hline 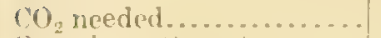 & 39.66 & 42.89 & 41.77 & 41. 49 \\
\hline Organic matter, etc & 9.96 & 4.11 & 4. 69 & 4.50 \\
\hline
\end{tabular}

Reduced anulyses of Heterocentrotus mammillatus.

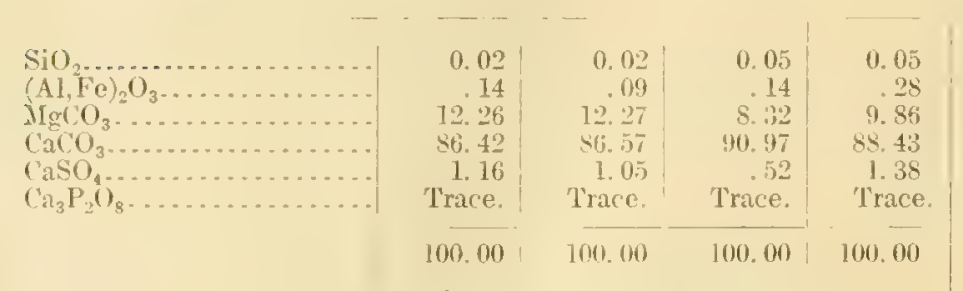

From these analyses we see that the inorganic constituents of Heterocentrotus are not uniformly distributed. The shell and teeth are alike and are rich in magnesium carbonate; the coarser spines are much less magnesian. The composition of the entire skeleton, if it can be called so, would probably be somewhere near that of the red spines alone, only a little higher in magnesia.

A similar example is offered by No. 8, Tretocidaris. In the specimen analyzed the shell and spines were taken separately, but the spines were dead when the urchin was collected. The analyses are as follows:

Actual analyses.

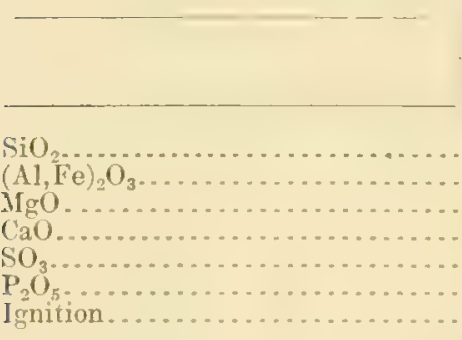

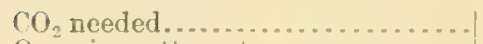

Organic matter, etc....................
Shell. | Spines.

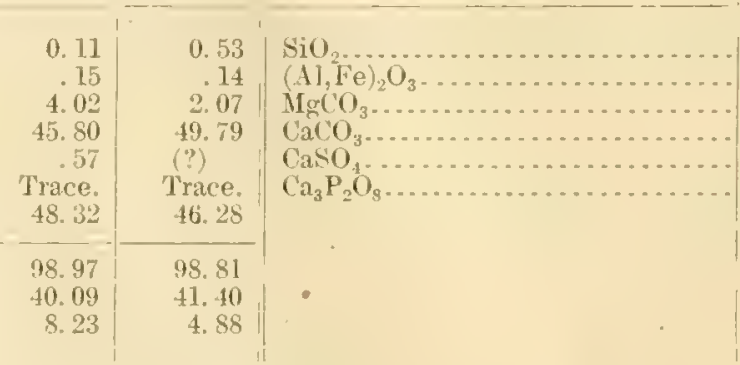

Reduced analyses.

Shell. Spines.

\begin{tabular}{r|r}
0.12 & 0.56 \\
.16 & .15 \\
9.30 & 4.63 \\
89.35 & 94.66 \\
1.07 & $(?)$ \\
Trace. & Trace. \\
\hline 100.00 & 100.00
\end{tabular}

Here again the spines are lower in their content of magnesia than the shell.

In two of the analyses, Nos. 4 and 5, large percentages of silica and sesquioxides appear. These are due to inclosed or adherent sand and mud, which were visible in the specimens but not readily removable. On rejecting these impurities and recalculating to 100 per cent, the percentages of magnesium carbonate became 11.43 and 8.59, respectively. Similar corrections to the other analyses are negligible. After making these corrections and assuming the percentages found for the shell rather than the spines in Nos. 8 and 9 , the next table has been constructed. If, howerer, the composition of the entire Heterocentrotus should be taken, it would fall below Encope californica. 
Percentage of magnesium carbonate in sen urehins.

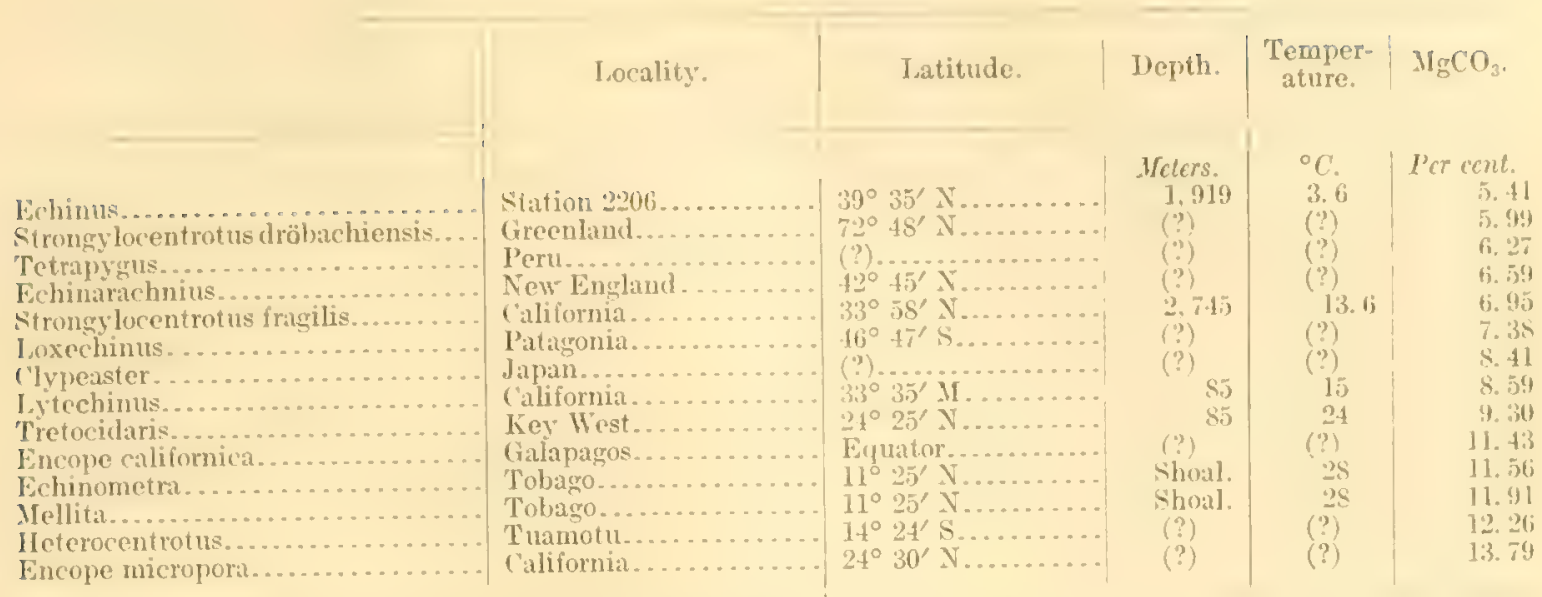

These figures, like those for the crinoids, seem to show a rariation dependent upon temperature, at least so far as temperatures hare been determined or can be inferred. The sen urchins from cold regions are relaticely low in magnesin; those from the Tropics are high. 'There are, howerer, two apparent exceptions. The urchin from the coast of Peru probably owes its abnormality to the cold Humboldt current, which flows northward from the Antarctic Ocean. Encope micropora is also seemingly anomalous, and its high percentage of magnesia is difficult to explain. Unfortunately the actual temperature of its habitat is not given.

Two published analyses of sea urchins are worth reproducing. They are:

1. Echinus (Strongylocentrotus?) diöbuchiensis. North Sea; analysis by I. Schmelek. Norske Nordhavs Exped., 5i. 29,1$) .129,1901$.

2. Eehinus csculentus. Tocality not stated, probably Mediteranean; analysis by o. Bütschli. K. (iesell. Wiss. (ionttingen $\mathrm{Abh}$., No. 3, 190s.

(1)der analyses of sen urehins.

\begin{tabular}{|c|c|c|c|c|c|}
\hline \multicolumn{3}{|l|}{ Actual analyses. } & \multicolumn{3}{|l|}{ Reduced analyses. } \\
\hline & $\mathrm{l}$ & 2 & 1 & 1 & 2 \\
\hline 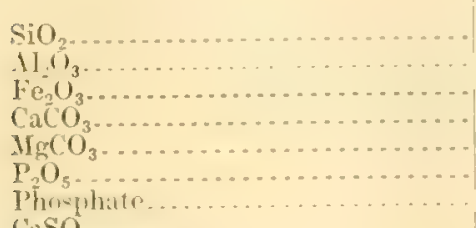 & $\begin{array}{r}\text { Trace. } \\
\text { Trare. } \\
0.30 \\
77.75 \\
5.30 \\
\text { Trace. } \\
\text { Ta..... }\end{array}$ & $\begin{array}{r}0.04 \\
\quad \ldots . \\
86.40 \\
8.53 \\
\quad .09\end{array}$ & 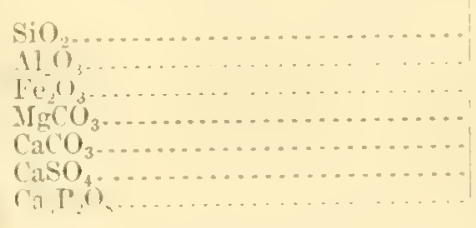 & $\begin{array}{c}\text { Trace. } \\
\text { Trace. } \\
11.34 \\
6.36 \\
93.28 \\
\text { Trace. } \\
\text { Trace. }\end{array}$ & $\begin{array}{r}0.04 \\
\quad .3 \\
8.84 \\
89.64 \\
1.40 \\
.08\end{array}$ \\
\hline $\begin{array}{l}\mathrm{CaSO}_{4} \mathrm{CaSO}_{4}, 2 \mathrm{H}_{2} \mathrm{O} \ldots \ldots \ldots \ldots \ldots \ldots \ldots \ldots \\
\mathrm{H}_{2} \mathrm{O} \ldots \ldots \ldots \ldots \ldots\end{array}$ & $\begin{array}{l}\text { Trace. } \\
16.33\end{array}$ & $\begin{array}{r}1.70 \\
2.54 \\
.03\end{array}$ & • & 100.00 & 100.00 \\
\hline & $99.6 \mathrm{~S}$ & 99.23 & & & \\
\hline
\end{tabular}

Mlthough different in minor details these analyses are fairly comparable with ours. The urchin analyzed by Schmelck was from the far north, and its composition is very near that of our specimen from Greenland. Bütschli's sea urchin is doubtless from warmer water and shows the higher figure for magnesium carbonatc.

\section{STAREISHES.}

In the former edition of this paper the starfishes and brittle stars were treated as one series, and only eleven analyses of them were made. Now, when a much larger mass of material is arailable, it is better to separate the two groups of organisms. Twenty-nine starfishes have been analyzed, of which two from Tobago were given us by Dr. Hubert L. Clark. 
The other specimens were selected by Mr. Austin H. Clark from the collection of the United States National Museum. The list is as follows:

1. Astcrias v'ulgaris Packard. Eastport, Maine; latitude, $44^{\circ} 55^{\prime} \mathrm{N}$.; longitude, $67^{\circ} 00^{\prime} \mathrm{W}$.

2. Asterias tanneri Verrill. Albalross station 2309 ; latitude, $35^{\circ} 43^{\prime} 30^{\prime \prime} \mathrm{N}$.; longitude, $74^{\circ} 52^{\prime}$ W.; depth, 102 meters; bottom temperature not given.

3. - Istcrina miniate 13randt. Pacific Grove, Calif.; latitude, $36^{\circ} 36^{\prime} \mathrm{K}$.; longitude, $121^{\circ} 55^{\prime} \mathrm{W}$.

1. Leptasterias compta Stimpson. Albatross station '2250; latitude, $40^{\circ} 17^{\prime} 15^{\prime \prime} \mathrm{N}$; longitude, $69^{\circ} 51^{\prime} 45^{\prime \prime} \mathrm{W}$; depth, $86^{\circ}$ meters; bottom temperature, $10.8^{\circ} \mathrm{C}$.

5. Benthopecten spinosus Verrill. Ilbatross station ' 2568 ; latitude, $39^{\circ} 15^{\prime} 00^{\prime \prime} \mathrm{X}$.; longitude, $68^{\circ} 08^{\prime} 00^{\prime \prime} \mathrm{W}$.; depth, 3,249 meters; bottom temperature, 2. $27^{\circ} \mathrm{C}$.

6. Luidia clathrata Say. Near Charleston, S. C.; latitude, $32^{\circ} 47^{\prime} \mathrm{X}$.; longitude, $79^{\circ} 57^{\prime} \mathrm{H}^{\prime}$; depth, between 2 and 22 meters.

7. Acanthaster planci Linné. P'almyra Island, in the Pacific Ocean, west of south from Hawaii, latitude, $5^{\circ} 49^{\prime} \mathrm{N}$.

S. Isterina minuta Gray. Pigeon Point, Tobaga, British West Indies; latitude, $11^{\circ} 25^{\prime} \mathrm{N}$.; shoal water near shore; temperature, $28^{\circ} \mathrm{C}$. Weight of specimen, "a large adult," only 0.1009 gram; a quantity insufficient for complete analysis.

9. Linckin guildingii Gray. Pigeon Point, Tobago, British West Indies; latitude, $11^{\circ} 25^{\prime} \mathrm{X}$.; shoal water near shore; temperature, $2 S^{\circ} \mathrm{C}$.

10. Ctenodiscus crispatus Retzius. Albatross station 2434; off Newfoundland; latitude, $43^{\circ} 08^{\prime} \mathrm{N}$.; longitude, $50^{\circ}$ $10^{\prime} \mathrm{W}$; ; depth, 93 meters; bottom temperature, $1,1^{\circ} \mathrm{C}$.

11. Odontaster hispidus Verrill. Off Marthas Vineyard, Mass; depth, 245 meters; bottom temperature, $11.1^{\circ} \mathrm{C}$.

12. Plutonaster agassizii Verrill. Off Marthas Vineyard, Mass.; depth, 584 meters; bottom temperature, $6.6^{\circ} \mathrm{C}$.

13. Asterias forbesii Desor. Vineyard Sound, Mass.

14. Pontaster tenuispinus Verrill. Albatross station 2095, between Cape Hatteras and Nantucket; latitude, $39^{\circ}$ $29^{\prime} \mathrm{N}$.; longitude, $70^{\circ} 5 S^{\prime} 40^{\prime \prime} \mathrm{W}$; d depth, 2,456 meters; bottom temperature not given.

15. Astropecten articulatus Say. West coast of Florida.

Analyses 8-15 by R. M. Kamm.

16. Orthasterias tanneri (Verrill). Albatross station 2307, between Caje Hatteras and Nantucket; latitude, $35^{\circ}$ $42^{\prime} \mathrm{N}$; ; longitude, $74^{\circ} 54^{\prime} 30^{\prime \prime} \mathrm{W}$; ; depth, 79 meters; bottom temperature, $14.5^{\circ} \mathrm{C}$.

17. Urasterias linckii (Müller and 'Troschel). East of Nova Scotia; latitude, $44^{\circ} 32^{\prime} \mathrm{N}$.; longitude, $57^{\circ} 09^{\prime} \mathrm{W}$.; depth, 403 meters. Weight of sample, 0.6226 gram.

18. Asterias acercata borealis Perrier. Western Bank, east of Nova Scotia.

19. Astropecten americanus Verrill. Off Marthas Vineyard, Mass.

20. 'Wataria bifascialis Gray. Cape San Lucas, Lower California; latitude, $22^{\circ} 52^{\prime} \mathrm{N}$.

21. I'haria pyramidata Gray. Cape San Lucas.

22. Orcaster occidentalis Verrill. San Jose Island, Gulf of California; latitude about $25^{\circ} \mathrm{N}$.

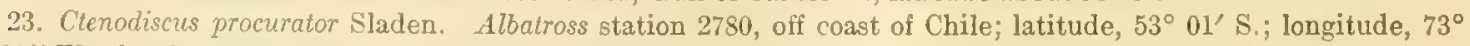
$42^{\prime} 30^{\prime \prime}$ W. d depth, 675 meters; bottom temperature, $8.3^{\circ} \mathrm{C}$.

24. Ctenodiscus australis Lütkin. Off Patagonia.

25. Narthastcrias glacialis (O. F. Müller). Horta Harbor, Azores; Jatitude, $35^{\circ} 35^{\prime} \mathrm{N}$.; longitude, $28^{\circ} 50^{\prime} \mathrm{W}$. approximately.

26. Asterina pectinifora Müller and Troschel. Otaru, Hokushu, Japan; latitude about $43^{\circ} \mathrm{N}$.

27. Culcita novaeguineae Müller and Troschel. An East Indian tropical species, locality unknown.

28. Linckia lacvigata (Linné). An East Indian tropical species, locality unknoẃn.

29. Coscinasterias calamaria Gray. New Zealand.

Analyses 16-29 by 3 . Salkover.

Analyses of starfishes.

\begin{tabular}{|c|c|c|c|c|c|c|c|}
\hline & 1 & 2 & 3 & 4 & 5 & 6 & 7 \\
\hline 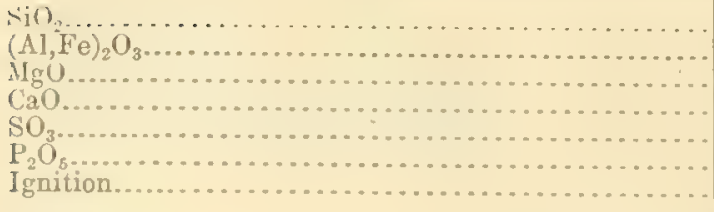 & $\begin{array}{r}0.47 \\
.21 \\
2.59 \\
35.71 \\
(?) \\
.07 \\
60.18\end{array}$ & $\begin{array}{l}0.79 \\
.55 \\
3.83 \\
38.51 \\
(?) \\
.24 \\
54.89\end{array}$ & $\begin{array}{r}0.113 \\
.20 \\
3.95 \\
36.85 \\
(?) \\
.14 \\
57.61\end{array}$ & $\begin{array}{r}1.21 \\
.48 \\
3.05 \\
30.35 \\
(?) \\
.13 \\
63.91\end{array}$ & $\begin{array}{r}2.06 \\
.79 \\
3.93 \\
40.54 \\
(?) \\
.11 \\
51.66\end{array}$ & $\begin{array}{r}0.27 \\
.36 \\
4.89 \\
41.30 \\
(?) \\
.14 \\
52.03\end{array}$ & $\begin{array}{r}0.19 \\
.14 \\
4.36 \\
33.18 \\
(?) \\
.07 \\
62.07\end{array}$ \\
\hline 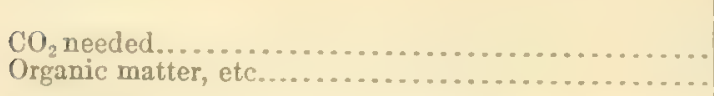 & $\begin{array}{l}99.21 \\
30.84 \\
29.34\end{array}$ & $\begin{array}{l}98.81 \\
34.30 \\
20.59\end{array}$ & $\begin{array}{l}98.84 \\
33.05 \\
24.59\end{array}$ & $\begin{array}{l}99.13 \\
27.08 \\
36.83\end{array}$ & $\begin{array}{l}99.09 \\
35.94 \\
15.72\end{array}$ & $\begin{array}{l}98.99 \\
37.70 \\
14.33\end{array}$ & $\begin{array}{r}100.01 \\
30.81 \\
31.26\end{array}$ \\
\hline
\end{tabular}


Analyses of starfishes-Continued.

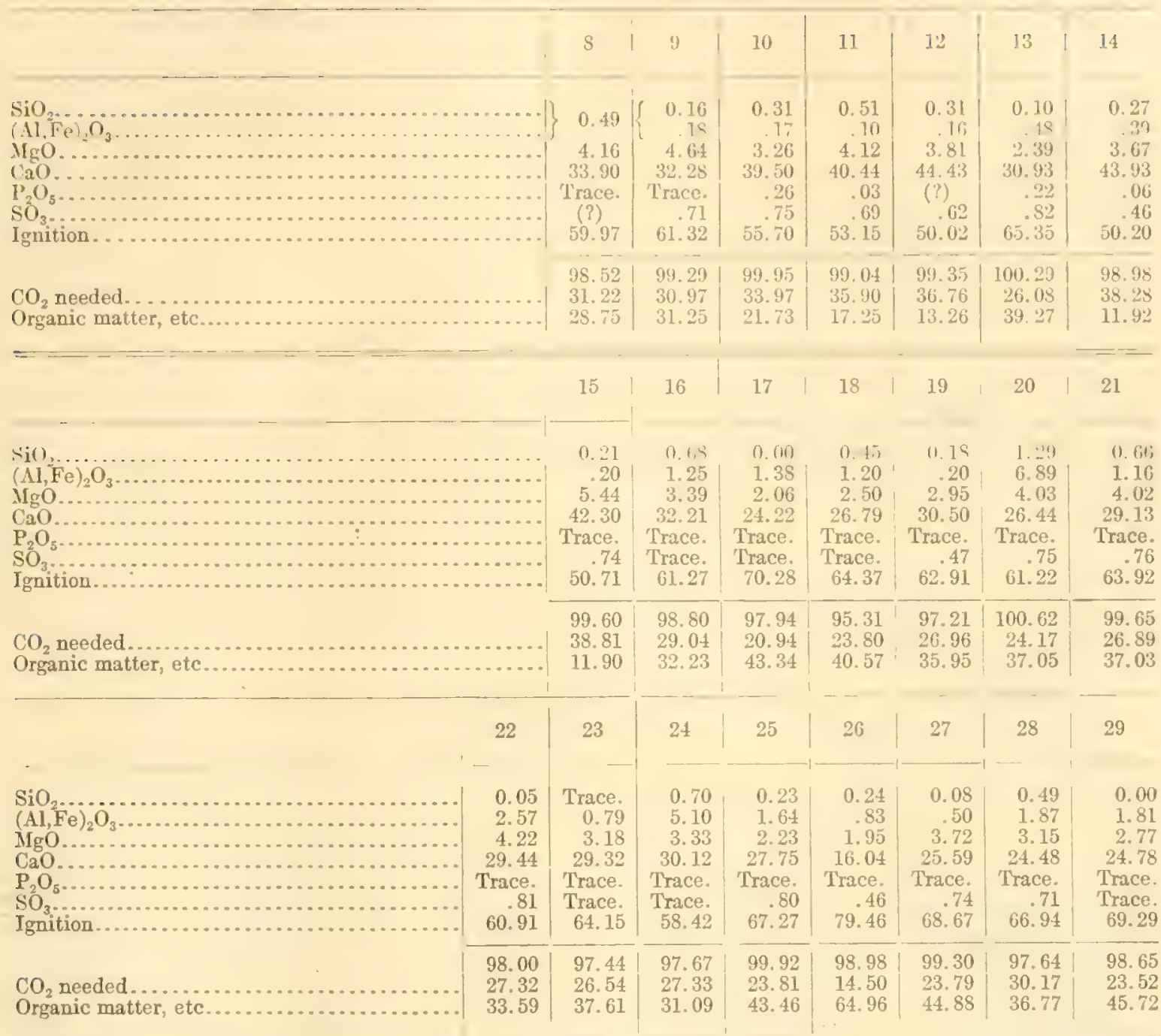

Reduced analyses of starfishes.

\begin{tabular}{|c|c|c|c|c|c|c|c|}
\hline & 1 & 2 & 3 & 4 & 5 & 6 & 7 \\
\hline \multirow[t]{3}{*}{ 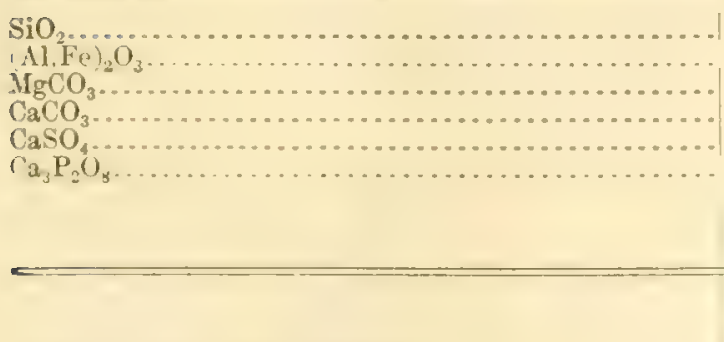 } & $\begin{array}{l}0.64 \\
.30 \\
7.79 \\
91.06 \\
(?) \\
.21\end{array}$ & $\begin{array}{r}1.01 \\
.70 \\
10.28 \\
87.44 \\
(?) \\
.5 .\end{array}$ & $\begin{array}{c}0.03 \\
11.27 \\
88.06 \\
(?) \\
.40\end{array}$ & $\begin{array}{r}1.94 \\
10.7 \\
86.57 \\
(?) \\
.45\end{array}$ & $\begin{array}{r}2.47 \\
.94 \\
9.88 \\
86.42 \\
(?) \\
.29\end{array}$ & $\begin{array}{c}0.32 \\
12.12 \\
86.77 \\
(?) \\
.36\end{array}$ & $\begin{array}{l}0.27 \\
.20 \\
13.33 \\
85.99 \\
(?) \\
\quad .21\end{array}$ \\
\hline & 100.00 & 100.00 & 100.00 & 100.00 & 100.00 & 100.00 & 100.00 \\
\hline & 8 & 9 & 10 & 11 & 12 & 13 & 14 \\
\hline \multirow[t]{2}{*}{ 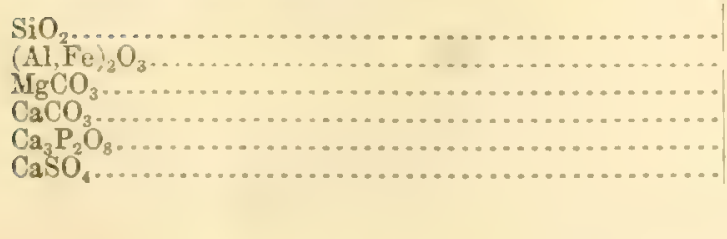 } & $\begin{array}{r}0.70 \\
12.53 \\
86.77 \\
\text { Trace. } \\
\text { (?) }\end{array}$ & $\left\{\begin{array}{r}0.24 \\
.26 \\
14.31 \\
83.42 \\
\text { Trace. } \\
1.77\end{array}\right.$ & $\begin{array}{r}0.39 \\
.22 \\
8.78 \\
88.48 \\
.73 \\
1.40\end{array}$ & $\begin{array}{r}0.62 \\
.12 \\
10.58 \\
87.16 \\
.08 \\
1.44\end{array}$ & $\begin{array}{l}0.35 \\
.19 \\
9.09 \\
89.18 \\
(?) \\
1.20\end{array}$ & $\begin{array}{r}0.17 \\
.78 \\
8.24 \\
88.19 \\
.78 \\
1.84\end{array}$ & $\begin{array}{r}0.31 \\
.45 \\
8.86 \\
89.34 \\
.15 \\
.89\end{array}$ \\
\hline & 100.00 & $\overline{100.00}$ & 100.00 & 100.00 & 100.00 & 100.00 & 100.00 \\
\hline
\end{tabular}


Reduced analyses of starfishes - Continued.

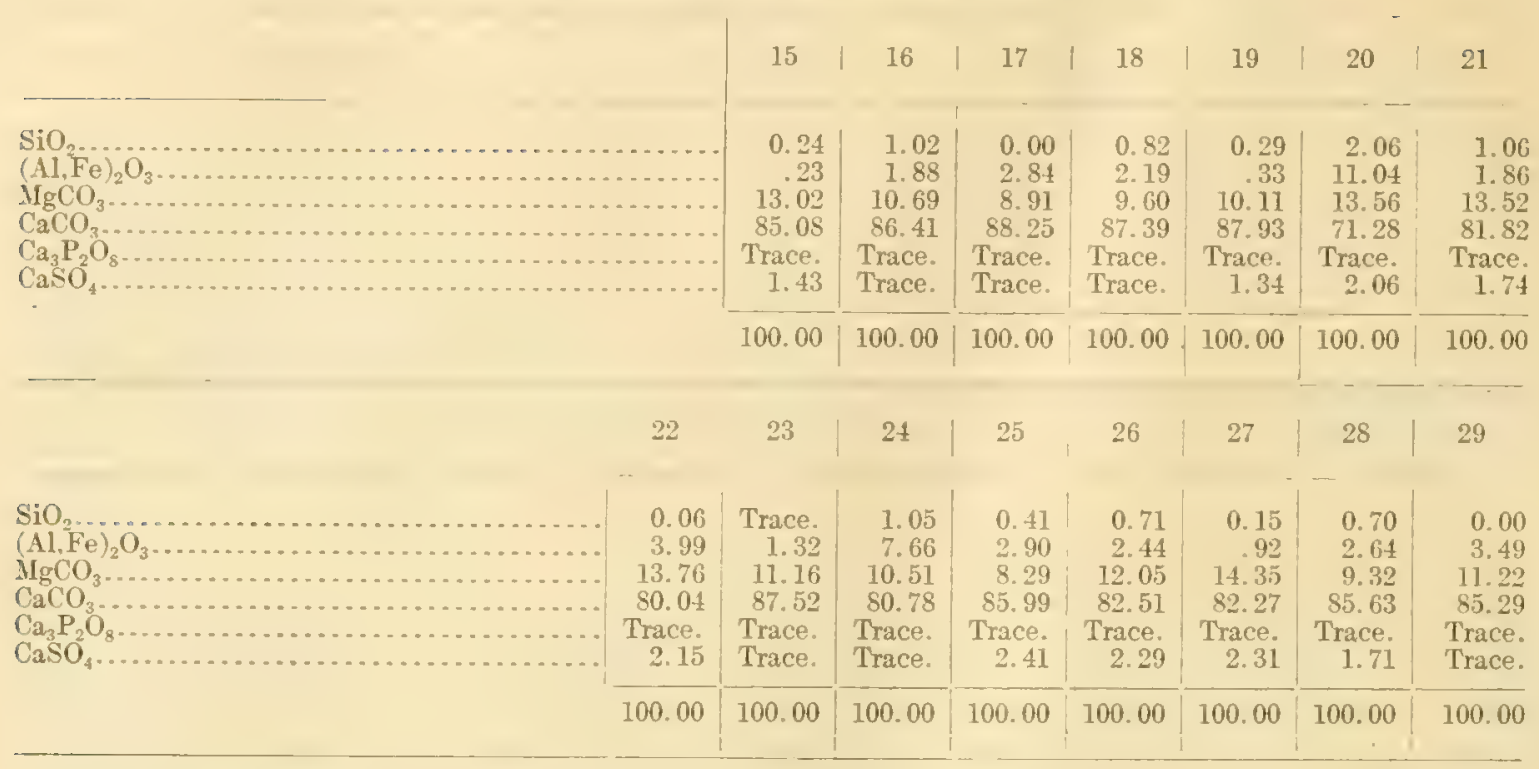

In the following table the analyses are arranged in the order of ascending magnesium carbonate, like those of the crinoids and sea urehins.

Magnesium carbonate in starfishes.

\begin{tabular}{|c|c|c|c|c|c|}
\hline & Locality: & Latitude. & Depth. & $\begin{array}{c}\text { Temper- } \\
\text { ature. }\end{array}$ & $\mathrm{IgCO}_{3}$ \\
\hline 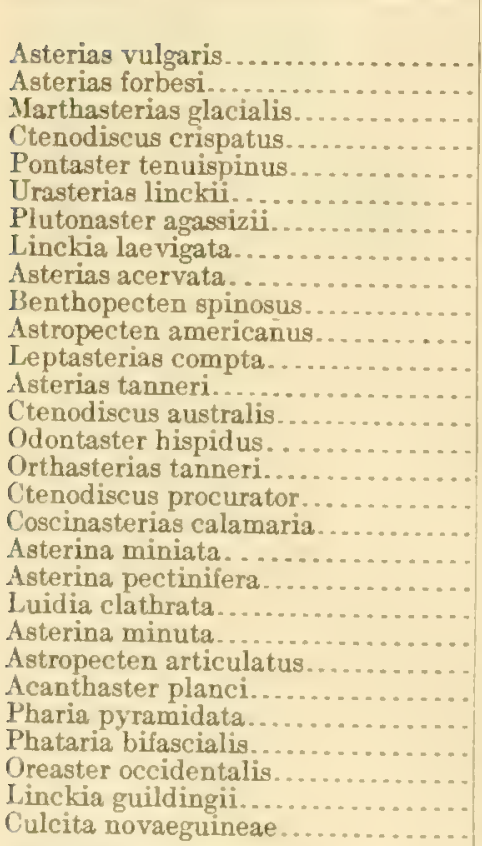 & 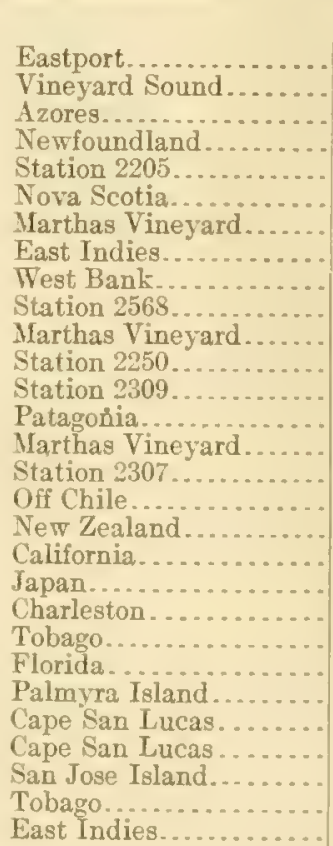 & 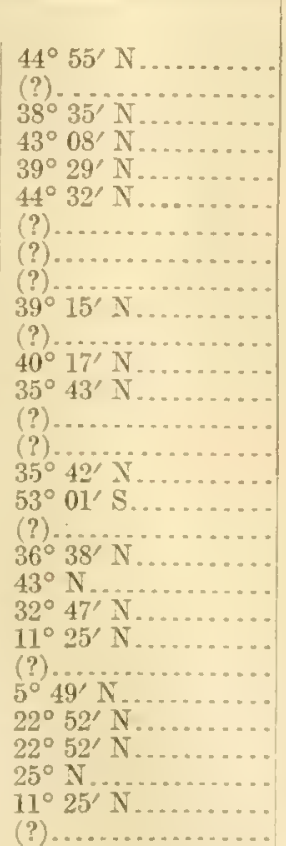 & $\begin{array}{c}\text { Ifeters. } \\
(?) \\
(?) \\
(?) \\
93 \\
2,456 \\
403 \\
584 \\
(?) \\
(?) \\
3.249 \\
(?) \\
106 \\
(?) \\
245 \\
67 \\
675 \\
(?) \\
(?) \\
(?) \\
(?) \\
\text { Shoal.... } \\
(?) \\
(?) \\
(?) \\
(?) \\
(?) \\
\text { Shoal.... } \\
(?)\end{array}$ & $\begin{array}{l}{ }^{\circ} \mathrm{C} . \\
(?) \\
(?) \\
(?) \\
(? .1 \\
(?) \\
(?) \\
\text { (?.6 } \\
(?) \\
(?) \\
2.7 \\
(?) \\
10.8 \\
(?) \\
(?) \\
11.1 \\
14.5 \\
8.3 \\
(?) \\
(?) \\
(?) \\
(?) \\
(?) \\
(?) \\
(?) \\
(?) \\
(?) \\
(?) \\
(?)\end{array}$ & $\begin{array}{r}\text { Per cent. } \\
7.79 \\
8.21 \\
8.29 \\
8.78 \\
8.86 \\
8.91 \\
9.09 \\
9.32 \\
9.60 \\
9.88 \\
10.11 \\
10.27 \\
10.28 \\
10.51 \\
10.58 \\
10.69 \\
11.16 \\
11.22 \\
11.24 \\
12.05 \\
12.13 \\
12.53 \\
13.02 \\
13.33 \\
13.52 \\
13.56 \\
13.76 \\
14.31 \\
14.35\end{array}$ \\
\hline
\end{tabular}

Here again we meet the same coordination of temperature with content of magnesium carbonate that was noted in the series of crinoids, sea urchins, and alcyonarians. As a general rule the species from cold regions are lowest in magnesia: those from warm regions are higher. 'The regularity, however, is not absolute, and the variations from it may be real, or perhaps may 
be due to differences in habitat. The starfishes from Vineyard Sound and Marthas Vinoyard, for example, may have come from different depths of water, and so, too, may the two marked as from the East Indies. Small impurities in the specimens analyzed may also account for some irregularities. The analyses by L. Schmelck, ${ }^{25}$ of starfishes from the North Sea, are, however, not so easy to explain. His data are as follows:

1. Arcaster lenuispinus. Station 10 ; latitude, $61^{\circ} 41^{\prime} \mathrm{N}$.; Iongitude, $3^{\circ} 19^{\prime} \mathrm{E}$.; depth, 402 meters; bottom tem. perature, $6^{\circ} \mathrm{C}$.

2. Arcaster lenuispinus. Station 25 ; latitude, $63^{\circ} 10^{\prime} \mathrm{N}$.; longitude, $5^{\circ} 25^{\prime} \mathrm{E}$; depth, 179 meters; bottom temperature, $6.9^{\circ} \mathrm{C}$.

3. Astropecten andromeda. Station 10; details under No. 1.

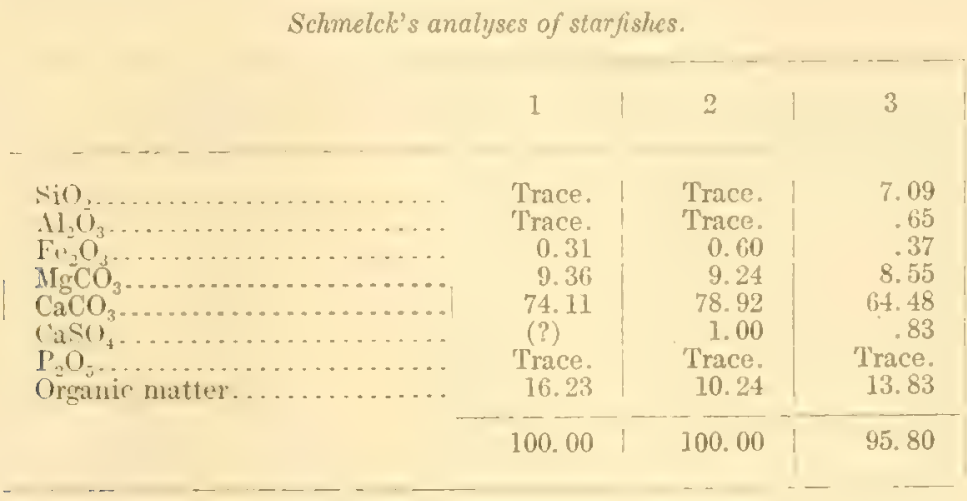

Schmelck's analyses reduced.

\begin{tabular}{|c|c|c|c|}
\hline & 1 & 2 & 3 \\
\hline \multirow[t]{2}{*}{ 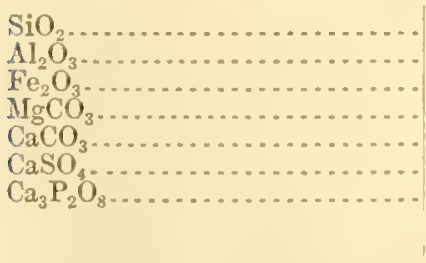 } & $\begin{array}{r}\text { Trace. } \\
\text { Trace. } \\
0.36 \\
11.18 \\
88.46 \\
\text { (?) } \\
\text { Trace. }\end{array}$ & $\begin{array}{r}\text { Trace. } \\
\text { Trace. } \\
0.66 \\
10.29 \\
87.92 \\
1.13 \\
\text { Trace. }\end{array}$ & $\begin{array}{r}8.66 \\
.79 \\
.45 \\
10.42 \\
78.67 \\
1.01 \\
\text { Trace. }\end{array}$ \\
\hline & 100.0 & 100.00 & 100.00 \\
\hline
\end{tabular}

Nos. 1 and 3 of this group of analyses represent the same locality and temperature. If the excessive and surely extraneous silica in No. 3 is rejected and the analyses are recalculated to 100 per cent the figure for magnesium carbonate becomes 11.41 , nearly that for No. 1 . Ail the percentages given for magnesium carbonate are higher than the temperatures would lead us to expect, but they still fall far below the highest ten in our table. A general tendeney to regularity as regards temperature is evident, but it is perhaps not inrariable.

\section{OPHIURANS OR BRITTLE STARS.}

The following data relate to the composition of the ophiurans, as distinguished from the ordinary starfishes.

1. Gorgonocephalus arcticus Gray. Off Cape Cod, Mass.; about latitude $42^{\circ} \mathrm{N}$.

2. Gorgonocephalus caryi Lyman. Alaska.

3. Ophioglypha sarsii Lütken. Albatross station 2176; latitude, $39^{\circ} 32^{\prime} 30^{\prime \prime} \mathrm{N}$; longitude, $72^{\circ} 21^{\prime} 30^{\prime \prime} W^{\prime}$.; depth, 553 meters; bottom temperature, $5^{\circ} \mathrm{C}$.

4. Ophioderma cinereum Müller and Troschel. Ensenada Honda, Culebra Island, east of Porto Rico; about latitude $18^{\circ} 20^{\prime} \mathrm{N}$.

5. Ophiomyxa flaccida Say. Pigeon Point, Tobago, British West Indies; Iatitude, $11^{\circ} 25^{\prime} \mathrm{N}_{\text {. }}$; shoal water, close in shore; temperature, $28^{\circ} \mathrm{C}$. Adult specimen.

25 Schmelck, L., Norske Nordhars Exped., No.28, p. 129, 1901. 
6. Like No. 5 ; half grown.

7. Ophiocoma pumila Lütken. Pigeon Point, Tobago. Like No. 5.

Analyses 5-7 by R. M. Kamm; specimens received from Dr. Hubert L. Clark.

8. Ophiocoma aethiops Lütken. Espiritu Santo Island, Gulf of California; about latitude $24^{\circ} 30^{\prime} \mathrm{N}$.

9. Ophiothrix angulata Ayres. Cuba.

10. Gorgonocephalus eucnemis Müller and Troschel. Albatross station 4912, 17 miles off Tsurikake Island, southern tip of Japan; latitude, $31^{\circ} 39^{\prime} 40^{\prime \prime} \mathrm{N}$.; longitude, $129^{\circ} 20^{\prime} \mathrm{W}$.; depth, 715.5 meters.

11. Ophiopholis aculeata japonica Lyman. Illiuluk, Unalaska; latitude, $53^{\circ} 42^{\prime} \mathrm{N}$.; longitude, $166^{\circ} 32^{\prime} \mathrm{W}$.

12. Ophioglyphe lymani (Ljungman). Off coast of Chile; latitude, $48^{\circ} 41^{\prime}$ S.; longitude, $74^{\circ} 24^{\prime}$ W.; depth, 355 meters; bottom temperature, $11.1^{\circ} \mathrm{C}$.

13. Ophiomusium lymani W. Thomson. Albatross station 3407; off the Galapagos Islands; latitude, $0^{\circ} 04^{\prime} \mathrm{S}$.; longitude $90^{\circ} 24^{\prime} 30^{\prime \prime} \mathrm{W}$.; depth, 1,619 meters; bottom temperature, $2.9^{\circ} \mathrm{C}$

14. Ophiocamax fasciculata Lyman, Albatross station 2125, Caribbean Sea; latitude, $11^{\circ} 43^{\prime} \mathrm{N}_{\text {.; }}$ longitude, $60^{\circ} 09^{\prime} 30^{\prime \prime} \mathrm{W}$; d depth, 381 meters; bottom temperature, $10.4^{\circ} \mathrm{C}$.

15. Ophionereis eurybrachiplax H. L. Clark. Albatross station 3702, off Honshu Island, Japan; depth, 57-75 meters.

16. Ophiocoma erinaceus Müller and Troschel. Hawailan Islands.

17. Ophioglypha lütkeni Lyman. Albatross station 3114, off central California; latitude, $37^{\circ} 06^{\prime} \mathrm{N}$.; longitude, $122^{\circ} 32^{\prime}$ W.; depth, 113.5 meters.

Analyses 8-17 by B. Salkover.

Analyses of ophiurans.

\begin{tabular}{|c|c|c|c|c|c|c|}
\hline & 1 & 2 & 3 & 4 & 5 & 6 \\
\hline 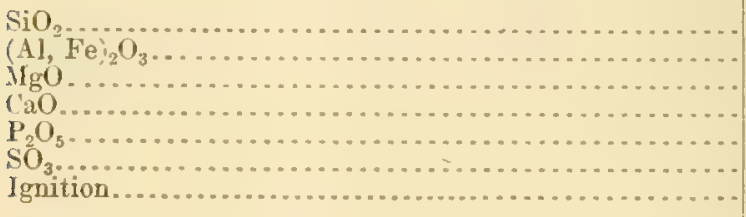 & $\begin{array}{r}1.77 \\
.62 \\
3.36 \\
36.13 \\
(? .22 \\
55.72\end{array}$ & $\begin{array}{r}1.08 \\
.72 \\
2.82 \\
29.80 \\
.32 \\
.69 \\
63.37\end{array}$ & $\begin{array}{r}0.98 \\
.53 \\
3.99 \\
42.14 \\
(? .29 \\
50.95\end{array}$ & $\begin{array}{r}0.21 \\
.09 \\
5.80 \\
41.32 \\
.07 \\
.16 \\
51.58\end{array}$ & \begin{tabular}{r|}
0.11 \\
.17 \\
4.67 \\
31.57 \\
Trace. \\
1.42 \\
61.09
\end{tabular} & $\begin{array}{r}0.43 \\
.55 \\
4.64 \\
30.14 \\
\text { Trace. } \\
1.60 \\
62.59\end{array}$ \\
\hline \multirow[t]{2}{*}{ 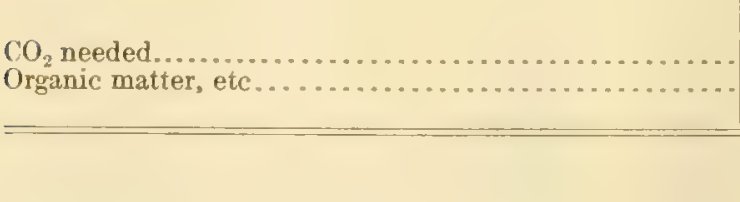 } & $\begin{array}{l}97.82 \\
31.65 \\
24.07\end{array}$ & $\begin{array}{l}98.80 \\
25.85 \\
37.52\end{array}$ & $\begin{array}{l}98.88 \\
37.29 \\
13.66\end{array}$ & $\begin{array}{l}99.23 \\
38.69 \\
12.89\end{array}$ & $\begin{array}{l}99.03 \\
29.17 \\
31.92\end{array}$ & $\begin{array}{l}99.95 \\
27.90 \\
34.69\end{array}$ \\
\hline & 7 & 8 & 9 & 10 & 11 & 12 \\
\hline 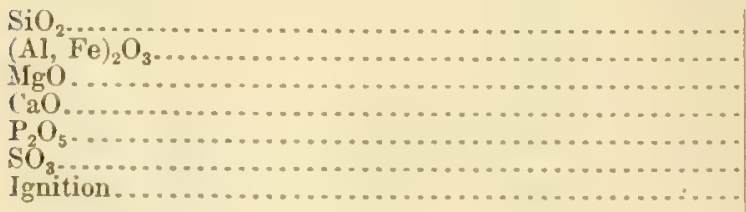 & $\begin{array}{r}0.36 \\
4.77 \\
37.20 \\
.05 \\
.90 \\
56.04\end{array}$ & $\begin{array}{r}0.10 \\
.67 \\
3.06 \\
47.12 \\
\text { Trace. } \\
\text { Trace. } \\
47.96\end{array}$ & $\begin{array}{l}0.26 \\
.67 \\
4.99 \\
42.18 \\
(?) \\
\text { (?) } \\
52.11\end{array}$ & $\begin{array}{r}0.17 \\
1.99 \\
2.72 \\
33.70 \\
\text { Trace. } \\
\text { Trace. } \\
61.51\end{array}$ & $\begin{array}{l}0.35 \\
.40 \\
3.44 \\
46.21 \\
(?) \\
(?) \\
49.74\end{array}$ & $\begin{array}{r}0.00 \\
1.64 \\
2.85 \\
36.44 \\
\text { Trace. } \\
\text { Trace. } \\
58.76\end{array}$ \\
\hline 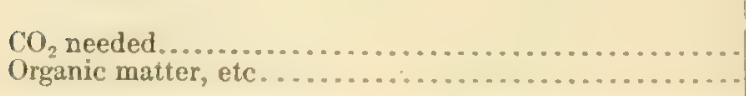 & $\begin{array}{l}99.32 \\
33.93 \\
22.11\end{array}$ & $\begin{array}{r}98.91 \\
40.39 \\
7.57\end{array}$ & $\begin{array}{r}100.21 \\
38.18 \\
13.93\end{array}$ & $\begin{array}{r}100.09 \\
29.47 \\
32.04\end{array}$ & $\begin{array}{r}100.14 \\
39.73 \\
10.01\end{array}$ & $\begin{array}{l}99.69 \\
31.77 \\
16.99\end{array}$ \\
\hline & \multicolumn{2}{|r|}{13} & 14 & 15 & 16 & 17 \\
\hline 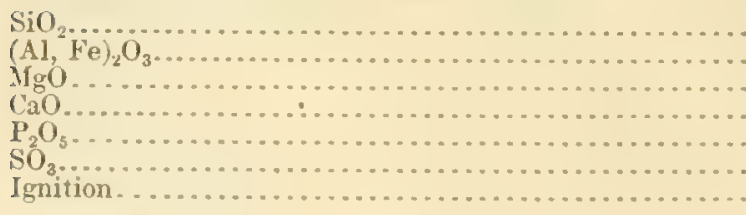 & T & $\begin{array}{l}0.00 \\
.67 \\
3.04 \\
50.09 \\
\text { Trace. } \\
\text { Trace. } \\
46.05\end{array}$ & $\begin{array}{r}0.00 \\
.95 \\
3.18 \\
44.80 \\
\text { Trace. } \\
\text { Trace. } \\
50.02\end{array}$ & $\begin{array}{r}0.00 \\
.89 \\
5.20 \\
39.09 \\
\text { Trace. } \\
\text { Trace. } \\
53.87\end{array}$ & $\begin{array}{r}0.00 \\
.94 \\
4.83 \\
40.91 \\
\text { Trace. } \\
\text { Trace. } \\
51.43\end{array}$ & $\begin{array}{r}0.00 \\
2.58 \\
3.61 \\
35.95 \\
\text { Trace. } \\
\text { Trace. } \\
55.21\end{array}$ \\
\hline 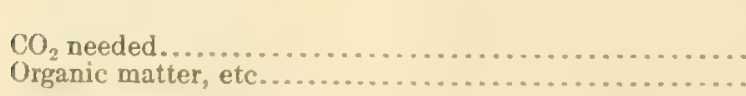 & & $\begin{array}{r}99.85 \\
42.79 \\
3.26\end{array}$ & $\begin{array}{l}98.95 \\
36.70 \\
13.32\end{array}$ & $\begin{array}{l}99.05 \\
36.43 \\
17.44\end{array}$ & $\begin{array}{l}98.11 \\
37.45 \\
13.98\end{array}$ & $\begin{array}{l}97.35 \\
32.22 \\
28.99\end{array}$ \\
\hline
\end{tabular}


Reduced analyses of ophiurans.

\begin{tabular}{|c|c|c|c|c|c|c|}
\hline & 1 & 2 & 3 & 4 & 5 & 6 \\
\hline \multirow[t]{3}{*}{ 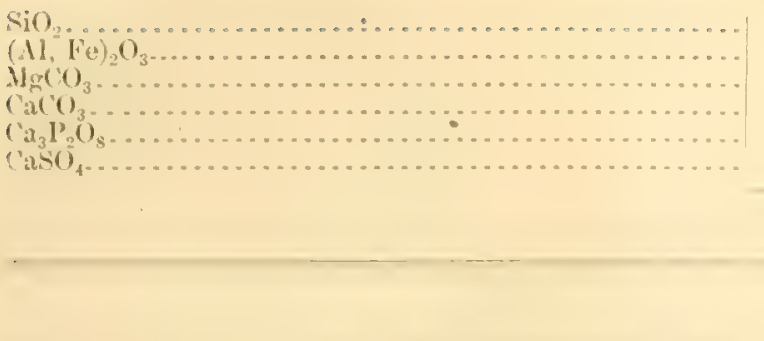 } & \begin{tabular}{r|}
2.39 \\
.84 \\
9. 53 \\
(?) 60 \\
(?)
\end{tabular} & $\begin{array}{l}\text { 1. } 76 \\
\text { 1. } 17 \\
\text { 9. } 66 \\
81.36 \\
\text { 1. } 14 \\
\text { 1. } 91\end{array}$ & $\begin{array}{r}1.15 \\
9.62 \\
9.84 \\
87.65 \\
.74\end{array}$ & $\begin{array}{r}0.21 \\
.11 \\
14.08 \\
85.09 \\
.18 \\
.30\end{array}$ & $\begin{array}{r}0.16 \\
.70 \\
14.56 \\
81.02 \\
\text { Trace. } \\
3.56\end{array}$ & $\begin{array}{r}0.66 \\
.85 \\
14.95 \\
79.37 \\
\text { Trace. } \\
4.17\end{array}$ \\
\hline & 100.00 & 100.0 & 100.00 & 100.00 & 100.00 & 100.00 \\
\hline & 7 & 8 & 9 & 10 & 11 & 12 \\
\hline \multirow[t]{3}{*}{ 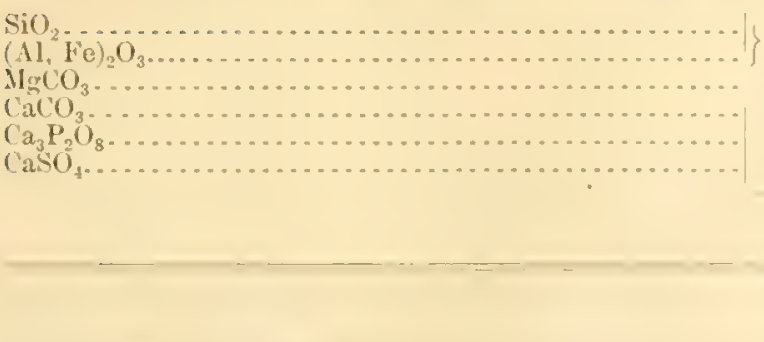 } & $\begin{array}{r}0.47 \\
12.97 \\
84.44 \\
.14 \\
1.98\end{array}$ & $\left\{\begin{array}{r}0.1 \\
.7 \\
7.0 \\
9.2 \\
\text { Trace } \\
\text { Trace }\end{array}\right.$ & $\begin{array}{l}0.31 \\
11.67 \\
\text { 11. } 68 \\
(?) .24 \\
(?)\end{array}$ & $\begin{array}{r}0.25 \\
2.92 \\
8.39 \\
88.44 \\
\text { Trace. } \\
\text { Trace. }\end{array}$ & $\begin{array}{l}0.39 \\
8.44 \\
8.01 \\
91.16 \\
(?) \\
(?)\end{array}$ & $\begin{array}{r}0.00 \\
2.26 \\
8.24 \\
89.50 \\
\text { Trace. } \\
\text { Trace. }\end{array}$ \\
\hline & 100.00 & $100 . \mathrm{C}$ & 100.00 & 100.00 & 100.00 & 100.00 \\
\hline & & 13 & 14 & 15 & 16 & 17 \\
\hline \multirow{2}{*}{\multicolumn{2}{|c|}{ 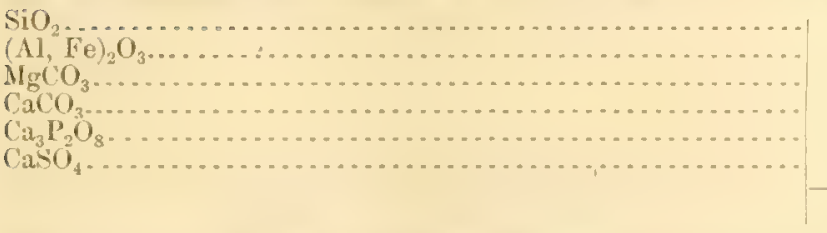 }} & $\begin{array}{r}0.00 \\
.69 \\
6.61 \\
92.70 \\
\text { Crace. } \\
\text { Irace. }\end{array}$ & $\begin{array}{c}0.00 \\
1.08 \\
7.62 \\
91.30 \\
\text { Trace. } \\
\text { Trace. }\end{array}$ & $\begin{array}{r}0.00 \\
1.09 \\
13.38 \\
85.53 \\
\text { Trace. } \\
\text { Trace. }\end{array}$ & $\begin{array}{r}0.00 \\
1.12 \\
12.05 \\
86.83 \\
\text { Trace. } \\
\text { Trace. }\end{array}$ & $\begin{array}{r}0.00 \\
3.47 \\
10.19 \\
86.34 \\
\text { Trace. } \\
\text { Trace. }\end{array}$ \\
\hline & & 00.00 & 100.00 & 100.00 & 100.00 & 100.00 \\
\hline
\end{tabular}

Some of these analyses are obviously incomplete, for phosphates and sulphates were not determined, because of insufficient material. A number of the specimens analyzed were fragments, and in that respect the analyses are not altogether satisfactory. In the following table the data are presented as in the tables for the other echinoderms; the figures for the two specimens of Ophiomyxa flaccida are averaged. The localities and latitudes are abbreviated as usual.

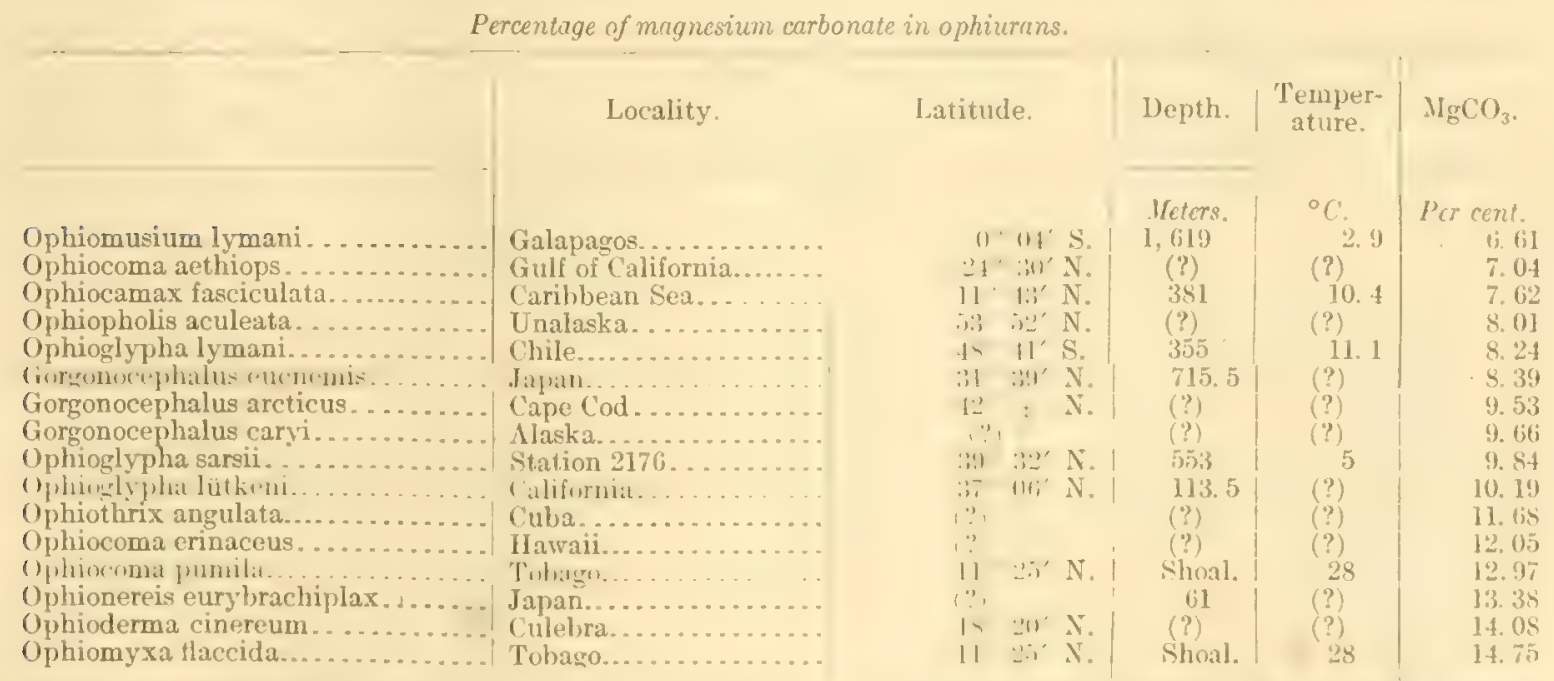

In this table the relation between magnesium carbonate and temperature is less regular than it was with the other echinoderms. Some of the low percentages are unaccountably low; but the last six in the series show percentages characteristic of warm-water organisms. One 
analysis of an ophiuran, Astrophyton, by L. Schmelck, ${ }^{26}$ remains to we noticed. The accompanying data are as follows: Locality, station 37 in the North Sea; latitude, $75^{\circ} 48^{\prime} \mathrm{N}$.; longitude, $8^{\circ} 57^{\prime} \mathrm{E}$; ; depth, 199 meters; bottom temperature, $1.1^{\circ} \mathrm{C}$.

Analysis of Astrophyton.

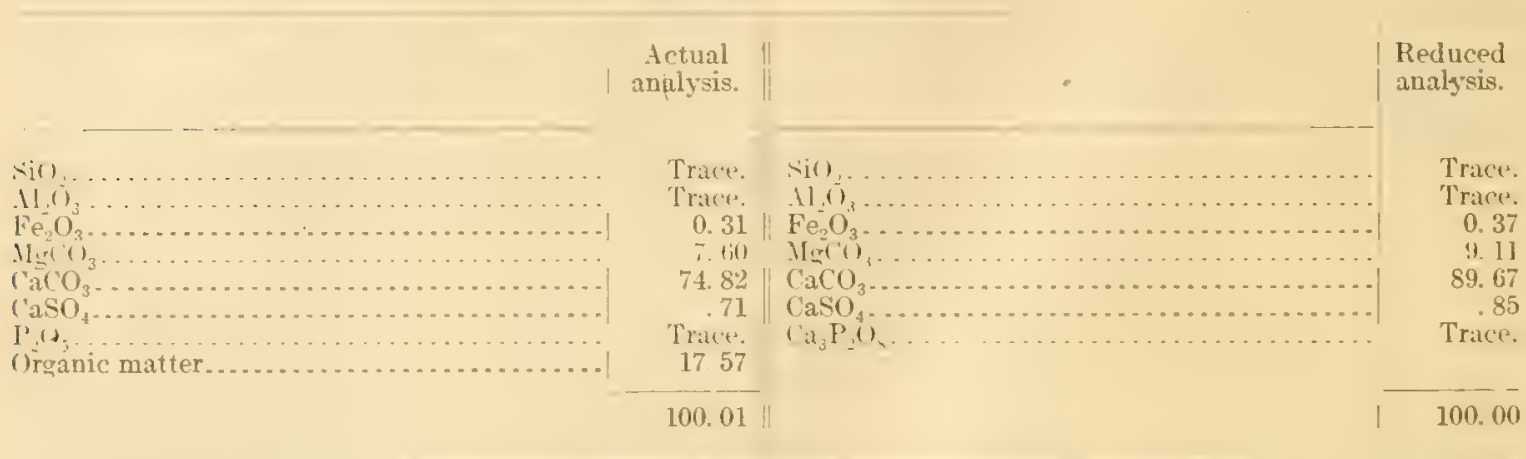

In this, as in Schmelck's analyses of starfishes, the magnesium carbonate is high for the temperature given.

5. HOLOTHURIANS.

Although the holothurians are of slight importance as contributors to the marine sediments, it seemed desirable to compare a few of them with the other echinoderms. Four holothurians were therefore analyzed, but their organic matter was so vastly in excess of their hard parts that the analyses, with one exception, are far from satisfactory. Howerer, the data, which are not without some significance, are as follows:

1. Hol thuria floridana Pourtalès. Fajardo, Porta Rico.

2. Cucumaria frondosa (Gunnerus). A northern cold-water species, precise locality unknown.

3. Trochostoma intermedium Ludwig. Otf Cerros Island, Calif. Weight of saraple, 0.2204 grano.

4. Trochostoma intermedium. Albatross station 3307, in Bering Sea; latitude, $56^{\circ} 12^{\prime} \mathrm{N}$.; longitude, $172^{\circ} 55^{\prime} \mathrm{W}$. depth of water, 130 meters; bottom temperature, $3.3^{\circ} \mathrm{C}$. Weight of sample, 0.1175 gram.

Analyses of holothurians.

\begin{tabular}{|c|c|c|c|c|}
\hline & 1 & 2 & 3 & 4 \\
\hline 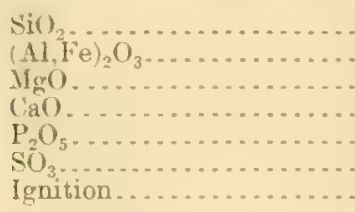 & $\begin{array}{r}0.08 \\
.18 \\
3.48 \\
29.19 \\
\text { Trace. } \\
.74 \\
69.93\end{array}$ & $\begin{array}{r}0.27 \\
.25 \\
.41 \\
1.10 \\
.85 \\
1.29 \\
95.71\end{array}$ & $\begin{array}{l}\text { 5. } 56 \\
\text { 8. } 40 \\
\text { 1. } 81 \\
\text { 4. } 91 \\
\text { 3. } 15 \\
\text { (?) } \\
\text { 76. } 71\end{array}$ & $\begin{array}{l}\text { 6. } 93 \\
6.31 \\
\text { 1. } 36 \\
\text { 1. } 44 \\
\text { 1. } 86 \\
\text { (?) } \\
82.21\end{array}$ \\
\hline $\begin{array}{l}\mathrm{CO}_{2} \text { needed........................... } \\
\text { Organic matter, etc. }\end{array}$ & $\begin{array}{l}99.60 \\
23.21 \\
46.72\end{array}$ & $\begin{array}{c}99.85 \\
(?) \\
(?)\end{array}$ & $\begin{array}{c}100.54 \\
(?) \\
(?)\end{array}$ & $\begin{array}{c}\text { 100. } 11 \\
\text { (?) } \\
\text { ? }\end{array}$ \\
\hline
\end{tabular}

In No. 2, 0.31 per cent of matter soluble in water was found, which raises the summation; to 100.19 .

Of these analyses only the first is reducible with any certainty to standard form. The percentage composition of the inorganic portion of the specimen then becomes-

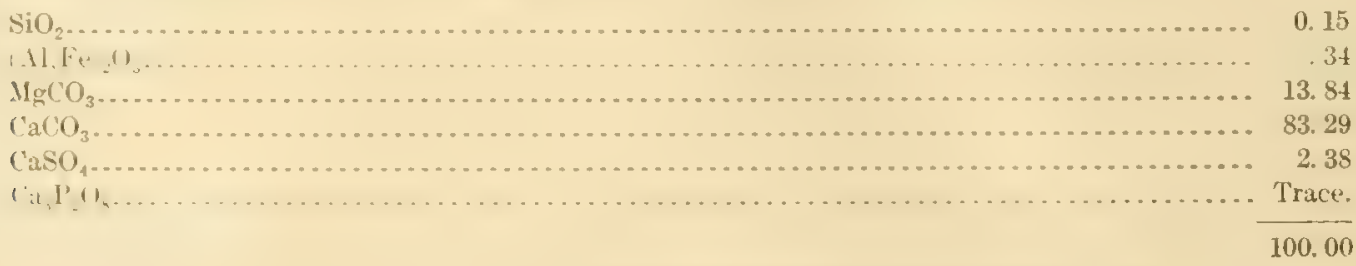

26 Schmelck, L., Norske Nordhavs Lxped., No. 2צ, p. 129, 1901. 
'This is very near the analysis of the ophiuran from Culebra Island, which is not far from the locality of this holothurian. The coincidence is very striking.

In the specimen represented by analysis 2 the proportion of inorganic matter was so small that good results could hardly be obtained. The other two analyses were also made with altogether inadequate material. These analyses, however, show that the small inorganic portions of the holothurians are relatively rich in phosphatic matter and in magnesia. 'The difficulties of discussing them intelligently are like those of discussing the worm tubes and the axes of alcyonarians. In Trochostoma there are brown spots, which were already known to be phosphatic, although quantitative analyses of them seem to be lacking. 'The true character of such bodies can be determined only by an elaborate investigation upon abundant material, a task which lies outside of our main problem.

Two analyses of holothurians are already on record, as follows:

1. Stichspus regalis. Locality not stated; analysis by O. Bütschli, K. Gesell. Wis. Göttingen .1hh., Xo. 3, 1905.

2. Ash of the epidermis ("lederhaut") of a large holothurian, species and locality not stated; analysis by Hilger. l'fluger's Archiv f. Physiologie, vol. 10, p. 212, 1875.

Old analyses of holothurians.

1
$\mathrm{Na} \mathrm{SO}_{2} \ldots \ldots \ldots \ldots \ldots \ldots \ldots \ldots \ldots \ldots$
$\mathrm{Na} 1$

These analyses, together with ours of Holothuria, show that the hard parts of these animals, like those of the other echinoderms, are distinctly magnesian. Although definite data are wanting, it seems probable that Hilger's specimen came from warmer water than that analyzed by Bütschli. The sodium salts are of course extraneous.

\section{SUMMARY.}

From the eridence now arailable it seems almost certain that the inorganic constituents of any echinoderm will have the composition of a moderately magnesian limestone. 'There may be exceptions, but none has yet been found. The five tables-for crinoids, sea urchins, starfishes, ophiurans, and holothurians - all tell the same story, and with remarkable unanimity. Furthermore, the proportion of magnesium carbonate appears to be a function of temperature, the organisms from warm waters being richer in it than those from cold waters. The exceptions to this rule are few and may be only apparent, for cold or warm currents and rarying depths of water account for nearly all irregularities. Schmelck's analyses of starfishes from the North Sea are the most troublesome to explain.

The sea urchins seem to be a little poorer in magnesia than either of the other groups, but the analyses are fewer and therefore less conclusire. Silica and sesquioxides are probably altogether extraneous, although it is possible that small quantities of them may really belong to the organisms. As shown by Meigen's reaction, all the echinoderms studied are calcitic, and no evidence of aragonite in them was found.

The temperature relations shown by the analyses offer an interesting biological problem, with which we can not undertake to cope. It is not due to differences of composition in the solid matter of sea water, for that is practically uniform the world over. In all the crreat oceans, and even in minor bodies of water like the Mediterranean, the Baltic, and the Black seas, the proportion of magnesia to lime is very nearly if not actually constant. In gaseous contents and especially in carbon dioxide the waters vary; the gases being more soluble in cold than in warm water. Whether this fact has any relation to the phenomenon under discussion we can not attempt to say. We ean only report the facts and leave their biological discussion to others. 


\section{BRYOZOA.}

Thirteen Bryozoa have been analyzed in the course of this research, as follows:

1. Schizoporella unicornis Johnston. Vineyard Sound. Mass; depth of water. 15.5 meters; bottom temperature, $20.5^{\circ} \mathrm{C}$.

2. Schizoporella unicornis Johnston. Between Johns Pass and Pass a Grille Fla.

3. Microporella grisea Lamouroux. Australia.

4. Cellepora incrassata Lamarck. Northeast part of the Grand Banks.

5. Flustra membranacea truncala Smith. St. Paul Island, Pribilof group, Alaska; latitude, $57^{\circ}$ N.; longitude, $170^{\circ} \mathrm{W}$. Only 0.1165 gram available for analysis.

6. Lepralia pallasiana Möller. Off Gloucester, Mass. A thin coating on a granite pebble; weight of organism, 0.4078 gram.

7. Lepralia rosterigera (Smitt). ('edar heys, Fla.

8. Holoporella albirostris (Smitt). ('edar Rapids, Fla.

9. Frondipora verrucosa Lamouroux. From the Naples Zoological Station, without definite statement as to locality.

10. Amathia spiralis Lamouroux. Albatross station 2619 , between Cape Hatteras and Charleston, S. C.; latitude, $33^{\circ} 38^{\prime} \mathrm{N}$; longitude, $77^{\circ} 30^{\prime} \mathrm{W}$; depth, 27.5 meters. Only 0.3 gram was available for analysis.

Analyses $7-10$ by R. II. Kamm.

11. Catenicella margaritacea Busk. Australia.

12. Bugula turrila Desor. Georges Bank, off coast of Massachusetts; Albatross station 2578; latitude, $41^{\circ} 20^{\prime} 30^{\prime \prime}$ Y. longitude $68^{\circ} 34^{\prime} 30^{\prime \prime} \mathrm{W}$; depth of water, 67.7 meters; bottom temperature, $12.4^{\circ} \mathrm{C}$.

13. Bugula ncritina Linné. Florida.

The actual analyses are as follows:

Analyses of Bryozoa.

\begin{tabular}{|c|c|c|c|c|c|c|c|}
\hline & 1 & 5 & & 3 & 4 & 5 & 6 \\
\hline 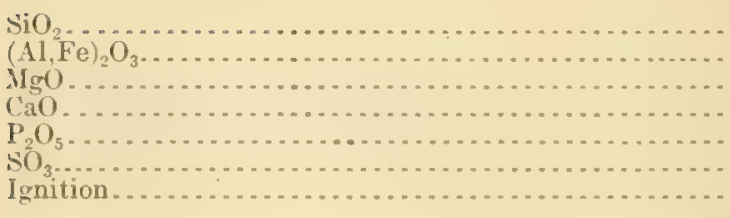 & 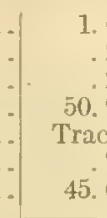 & $\begin{array}{l}65 \\
29 \\
28 \\
90 \\
c e . \\
73 \\
64\end{array}$ & $\begin{array}{l}49 \\
37 \\
04 \\
17 \\
77 \\
70\end{array}$ & $\begin{array}{r}0.17 \\
.11 \\
50.49 \\
53 \\
.10 \\
.79 \\
46.80\end{array}$ & $\begin{array}{r}0.19 \\
.19 \\
2.74 \\
49.46 \\
\text { Trace. } \\
.98 \\
46.03\end{array}$ & $\begin{array}{r}3.00 \\
2.06 \\
30.81 \\
.09 \\
(?) \\
61.45\end{array}$ & $\begin{array}{r}\text { 4. } 78 \\
.13 \\
2.32 \\
43.08 \\
.11 \\
(?)^{-}\end{array}$ \\
\hline $\mathrm{o}_{2}$ needed $\ldots$ & $\begin{array}{r}99 . \\
39 . \\
5 .\end{array}$ & & $\begin{array}{l}54 \\
16 \\
54\end{array}$ & $\begin{array}{r}99.29 \\
39.94 \\
6.86\end{array}$ & $\begin{array}{r}99.49 \\
41.26 \\
5.06\end{array}$ & $\begin{array}{l}97.41 \\
26.39 \\
35.06\end{array}$ & $\begin{array}{l}50.42 \\
36.29 \\
13.29\end{array}$ \\
\hline & 71 & 8 & 9 & 10 & $\begin{array}{ll}\text { | } & 11\end{array}$ & 12 & 13 \\
\hline 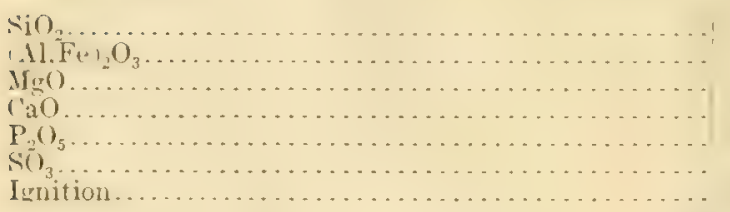 & $\begin{array}{r}0.36 \\
.39 \\
1.25 \\
50.54 \\
\text { Trace. } \\
45.96\end{array}$ & $\begin{array}{r}0.55 \\
1.16 \\
50.94 \\
\text { Trace. } \\
.86 \\
45.87\end{array}$ & $\left\{\begin{array}{r}1.27 \\
.64 \\
.07 \\
48.51 \\
\text { Trace. } \\
1.49 \\
44.00\end{array}\right.$ & $\begin{array}{r}5.75 \\
.31 \\
3.44 \\
(?) \\
(?) \\
18.79\end{array}$ & $\left\{\begin{array}{r}0.95 \\
.41 \\
3.50 \\
40.83 \\
.16 \\
1.00 \\
52.66\end{array}\right.$ & $\begin{array}{r}8.77 \\
1.18 \\
2.55 \\
20.45 \\
.38 \\
1.47 \\
61.51\end{array}$ & $\begin{array}{r}6.31 \\
.75 \\
2.57 \\
19.69 \\
.60 \\
2.43 \\
59.47\end{array}$ \\
\hline 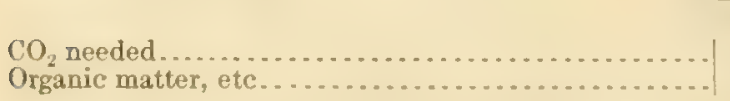 & $\begin{array}{r}99.30 \\
40.64 \\
5.32\end{array}$ & $\begin{array}{r}99.38 \\
40.83 \\
5.04\end{array}$ & $\begin{array}{r}95.98 \\
37.38 \\
6.62\end{array}$ & $\begin{array}{r}98.29 \\
3.04 \\
85.75\end{array}$ & $\begin{array}{l}99.51 \\
35.23 \\
17.43\end{array}$ & $\begin{array}{l}96.31 \\
17.69 \\
43.82\end{array}$ & $\begin{array}{l}91.82 \\
16.41 \\
43.06\end{array}$ \\
\hline
\end{tabular}

Reduced analyses of Bryozoa.

\begin{tabular}{|c|c|c|c|c|c|c|}
\hline & 1 & 2 & 3 & 4 & 5 & 6 \\
\hline \multirow[t]{2}{*}{ 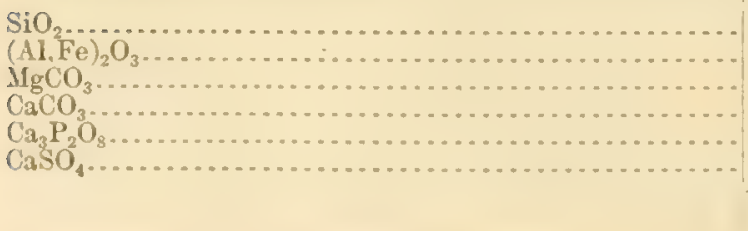 } & $\begin{array}{r}1.77 \\
.31 \\
.63 \\
95.97 \\
\text { Trace. } \\
1.32\end{array}$ & $\begin{array}{r}2.66 \\
.39 \\
4.58 \\
90.90 \\
\text { Trace. } \\
\text { 1. } 40\end{array}$ & $\begin{array}{r}0.18 \\
.12 \\
1.11 \\
96.90 \\
.24 \\
1.45\end{array}$ & $\begin{array}{r}0.20 \\
.20 \\
6.07 \\
91.77 \\
\text { Trace. } \\
1.76\end{array}$ & $\begin{array}{r}4.82 \\
6.91 \\
87.92 \\
(?)^{32}\end{array}$ & $\begin{array}{r}5.52 \\
5.15 \\
88.44 \\
.27\end{array}$ \\
\hline & 100.00 & 100.00 & 100.00 & 100.00 & 100.00 & 100.00 \\
\hline
\end{tabular}


Reducel analyses of Bryozoa-Continued.

\begin{tabular}{|c|c|c|c|c|c|c|c|}
\hline & 7 & 8 & 9 & 10 & 11 & 12 & 13 \\
\hline \multirow[t]{2}{*}{ 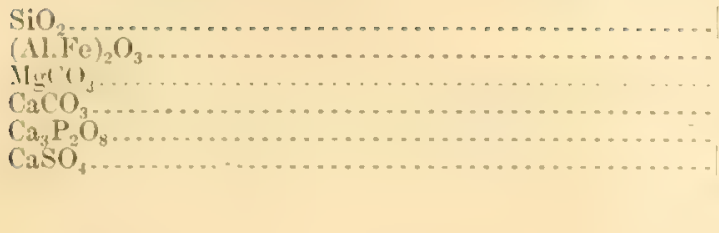 } & $\begin{array}{r}0.38 \\
.41 \\
94.96 \\
94.96 \\
\text { Trace. } \\
\text { 1. } 45\end{array}$ & $\begin{array}{r}0.59 \\
2.34 \\
95.29 \\
\text { Trace. } \\
\quad 1.51\end{array}$ & $\left\{\begin{array}{r}1.42 \\
.72 \\
17 \\
91.86 \\
\text { Trace. } \\
2.83\end{array}\right.$ & $\begin{array}{c}9.71 \\
90.43 \\
(?) \\
(?)\end{array}$ & 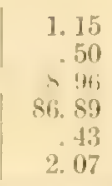 & $\begin{array}{r}\text { 16. } 71 \\
2.25 \\
\text { 11) } 1: 1 \\
\text { fit. } 51 \\
\text { 1. } 58 \\
\text { 4. } 76\end{array}$ & $\begin{array}{r}\text { 12. } 91 \\
1.54 \\
11.114 \\
6.3 .29 \\
\text { 2. } 68 \\
8.47\end{array}$ \\
\hline & 100.00 & 100.00 & 100.00 & 100.00 & 100.00 & .100 .00 & 100.00 \\
\hline
\end{tabular}

Reduced analysis No. 10, of Amathia, requires explanation. This bryozoan was one of the mossy or fernlike forms and contained inclusions of sand and minute shells. Its organic matter was very large, and the entire material arailable was insufficient for a good analysis. The figures giren for it in this table merely represent the lime and magnesia alone, calculated as carbonates and to 100 per cent. The analysis is obriously of small significance, except in so far as it gires the ratio between magnesia and lime. To that extent it has some value.

Bryozoa Nos. 1 to 5 and 7 to 9 were massive coralline forms and were easily handled. No.6, Lepralia, was an incrustation upon a pebble, from which it could not well be separated mechanically. The entire specimen was therefore weighed, the bryozoan was then dissolred by hydrochloric acid, and the pebble was, weighed again. The solution only was available for analysis, and the usual loss on ignition could not be determined but was necessarily taken by difference. Such an analysis is obriously unsatisfactory but not entirely worthless. Bryozoa Nos. 10 to 13 were delicate mossy or fernlike organisms, and the poor summations of the last two indicate the presence of undetermined saline matter. The high silica in them is evidently due to inclosed sand. If silica and sesquibxides are rejected and the-remainders recalculated to 100 per cent the percentages of magnesium carbonate become 12.51 and 12.95 , respectively. The magnesia, however, shows no such regularity as regards temperature as appears in our series of alcyonarians and echinoderms. The difference between the magnesian content of the two specimens of Schizoporella is very striking. What this difference may signify is yet to be determined.

Several other analyses of Bryozon, complete or partial, are recorded in the literature. 'Two of them, fairly complete, were made by $\Lambda$. Schwager for J. Walther. ${ }^{27}$ They are as follows, both specimens being from the Bay of Naples:

1. Eschara foliacea.

2. Lepralia sp.

Schtrager's analyses of Bryozoa.

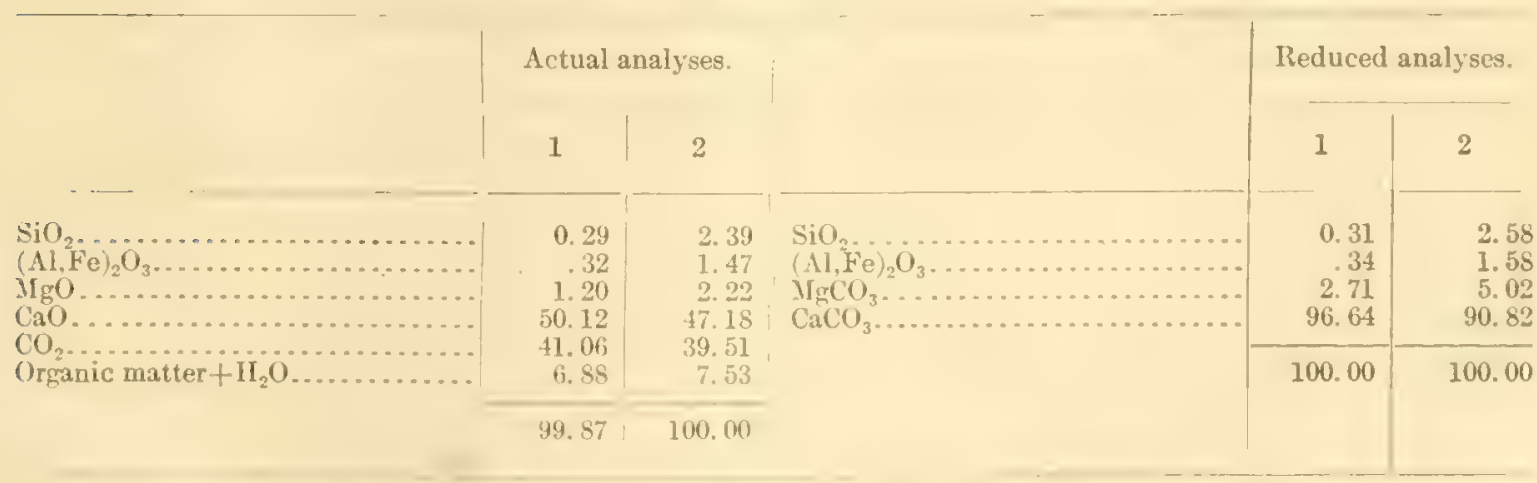

${ }^{27}$ Walther, J., Deutsch. geol. Gesell. Zeitschr., vol. 37 , p. 33s, 1 ssj. 
The reduced analyses were computed by us from Schwager's data.

In Flustra foliacea from California H. WT. Nichols ${ }^{28}$ found 1.23 per cent of magnesium carbonate, and in a bryozoan from Bermuda 5.35 per cent. Several similar determinations by G. Forchhammer ${ }^{29}$ on other Bryozoa gave less than 0.6 per cent. The other constituents of the organisms were not determined, and the figures given for magnesium carbonate therefore have little present ralue.

From the eridence now at hand no broad general conclusions can be drawn. That the magnesian content of the Bryozoa raries widely, however, is clear, being lowest in the compact coralline forms and highest in the fernlike varieties. Eren this conclusion needs to be verified by a much larger series of analyses.

\section{BRACHIOPODS.}

A few analyses of brachiopod shelis already on record show that they fall into two chemically distinct groups - one calcareous, the other highly phosphatic. This conclusion is supported and emphasized by the new data obtained by us, which also bring out some minor peculiarities that seem not to have been previously observed. For our material we are indebted to Dr. W. H. Dall, who selected typical specimens from among the duplicates in the United States National Museum. First in order come five brachiopods representing as many genera in the calcareous group. The analyses are as follows:

l. Terebratula cubensis Pourtalès, Coast of Florida.

2. Terebratulina septentrionalis Gray. Eastport, Mfaine.

3. Laqueus californicus Koch. Esteros Bay, Calif.

4. Rhynchonella psittracca Gmelin. Shetland Islands.

5. Crania anomala Müller. Coast of Norway.

Analyses of calcareous brachiopods.

$\ldots \ldots \ldots \ldots$
$\ldots$

Rejecting organic matter and recalculating to 100 per cent, the analyses assume the following rational form:

Reduced analyses of calcareous brachiopods.

\begin{tabular}{|c|c|c|c|c|c|}
\hline & 1 & 2 & 3 & 4 & 5 \\
\hline \multirow{2}{*}{ 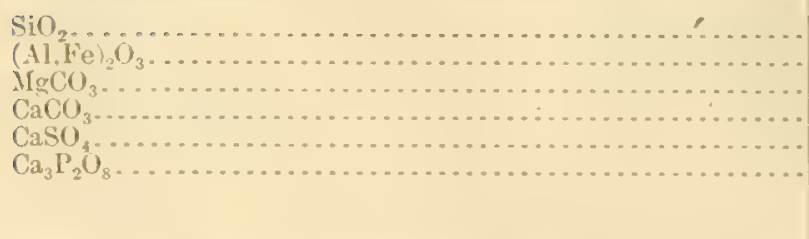 } & $\begin{array}{r}0.06 \\
.04 \\
.93 \\
98.61 \\
.36 \\
\text { Trace. }\end{array}$ & $\begin{array}{r}0.52 \\
.15 \\
1.37 \\
96.78 \\
1.18 \\
\text { Trace. }\end{array}$ & $\begin{array}{r}0.18 \\
.48 \\
.68 \\
98.30 \\
.36 \\
\text { Trace. }\end{array}$ & $\begin{array}{r}0.15 \\
.23 \\
.49 \\
98.20 \\
.55 \\
.38\end{array}$ & $\begin{array}{r}0.22 \\
.27 \\
8.63 \\
88.59 \\
1.72 \\
.57\end{array}$ \\
\hline & 100.00 & 100.00 & 100.00 & 100.00 & 100.00 \\
\hline
\end{tabular}


For comparison the following analyses of calcareous brachiopods, made elsewhere, are significant:

6. Terebratula sp. Collected by Pourtales hetween Florida and Cuba; S. P. Sharples, analyst.;

7. Terebratulina caput serpentis. Locality not given; F. Kunckell, analyst. ${ }^{31}$

8. Crania anomala Müller. Locality not given; L'. Kunckell, analyst.

9. Waldheimia cranium Müller. Locality not given; H'. Kunckell, analyst.

10. Waldheimia cranium. Collected by the Norwegian North Sea Expedition, station 255; latitude, $65^{\circ} 12^{\prime}$ N.; longitude, $15^{\circ} 40^{\prime} \mathrm{E}$; depth, $62+$ meters; bottom temperature, $6.5^{\circ} \mathrm{C}$.

11. Waldheimia cranium. Iofoten Islands.

Analyses 10 and 11 by L. Schmelck. ${ }^{32}$

Older analyses of calcareous brachiopods.

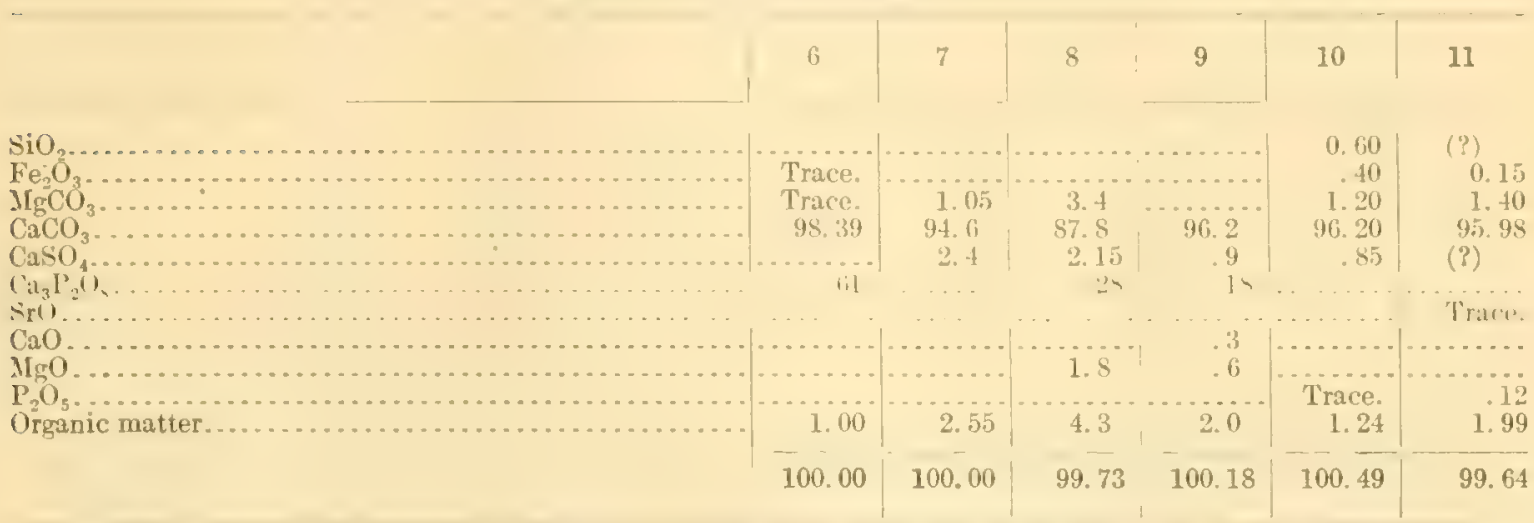

With these analyses ours agree in a broad, general way, although the older ones rary much as regards completeness. Kunckell's analyses, showing free lime and magnesia, are suspicious, but only in this detail; otherwise they have confirmatory value. All the analyses show that brachiopods of this group have shells in which calcium carbonate is the principal constituent and that the proportion of organic matter is low. The only aberrant one is Crania, which is noteworthy on account of its high percentage of magnesia. In this respect, Kunckell's analysis, if recalculated to a common basis, agrees approximately with ours. Rhynchonella is also interesting for the reason that an analysis by Hilger of shells supposed to belong to this genus indicates that they are phosphatic and practically identical in composition with those of Lingula. The authenticity of Hilger's material is questionable, and his analysis will not be reproduced here.

Four analyses of shells of phosphatic brachiopods have been made by us. As these shells contain a large amount of organic matter, which possibly varies with the age or maturity of the animal, we prefer to report our results, as others before us have done, in proximate rather than ultimate form. The analyses are as follows:

1. Lingula anatina Gmelin. Coast of Higo Province, Japan. Organic matter, rejected, 40 per cent.

2. Lingula anatina. Iloilo, Philippine Islands. Organic matter, rejected, 39.5 per cent.

3. Discinisca lamellosa Broderip. Coast of Peru. Organic matter, rejected, 25 per cent.

4. Glottidia (formerly Lingula) pyramidata Stimpson, coast of North Carolina. Organic matter, about 37 per cent; analysis incomplete for lack of sufficient material.

Analyses of phosphatic brachiopods.

\begin{tabular}{|c|c|c|c|c|}
\hline 1 & 1 & 2 & 3 & 4 \\
\hline \multirow[t]{2}{*}{$\begin{array}{l}\mathrm{SiO} \\
(\mathrm{Al}, \mathrm{Fe})_{2} \mathrm{O}_{3} \ldots \ldots \ldots \\
\mathrm{IgCO}_{3} \ldots \ldots \ldots \\
\mathrm{CaCO}_{3} \ldots \ldots \ldots \ldots \ldots \\
\mathrm{CaSO}_{4} \ldots \ldots \ldots \ldots \ldots\end{array}$} & $\begin{array}{r}0.91 \\
.54 \\
2.70 \\
1.18 \\
2.93 \\
91.74\end{array}$ & $\begin{array}{r}0.50 \\
.29 \\
.79 \\
4.25 \\
4.18 \\
89.99\end{array}$ & $\begin{array}{r}0.85 \\
.58 \\
6.68 \\
8.35 \\
8.37 \\
75.17\end{array}$ & $\begin{array}{l}0.49 \\
1.16 \\
1.71 \\
(?) \\
\text { (?) } \\
74.73\end{array}$ \\
\hline & 100.00 & 100.00 & 100.00 & \\
\hline
\end{tabular}

30 Sharples, S. I'., Am. Jour. Sci., 3d ser., vol. I, p. 168, 1571.

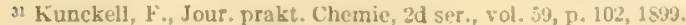


These analyses are noteworthy on account of the unusual proportion of calcium sulphate reported in them. Discinisca is especially remarkable in this respect and also in its percentage of magnesium carbonate. Small amounts of sulphates have been found in many mollusks and corals as well as in the calcareous brachiopods but in nothing like the proportion given here. $\Lambda$ new analysis of Discinisca made upon fresh material is much to be desired.

In the older analyses of this group the sulphate seems to have been ignored, or at least to have escaped attention. The figures are as follows:

5. Lingula ovalis. Hawaiian Islands; T. S. Hunt, analyst. ${ }^{33}$

6, 7. Lingula ovalis. Locality not given; A. Hilger, analyst. ${ }^{34}$

8. Lingula anatina. S. Cloëz, analyst ${ }^{35}$ recalculated to 100 per cent after rejecting 42.6 per cent of organic matter. Older analyses of phosphatic brachiopods.

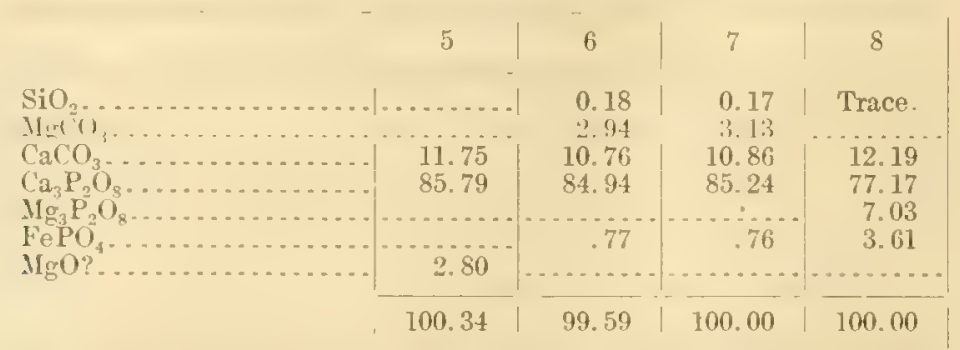

The relatively high figures for calcium carbonate shown in this table are doubtless due to the neglect to determine sulphate. The analysis by Cloëz differs from the others principally in form-that is, in its mode of calculation. If the phosphoric oxide in it is assigned entirely to the lime, then the proportion of calcium phosphate becomes 88.6 per cent, which is well in line with the other figures. The amount of calcium carbonate would be correspondingly reduced.

The brachiopods, as stated at the beginning of this section, fall into two distinct groups; the shells of one consist mainly of calcium carbonate, with little organic matter, and those of the other predominatingly of calcium phosphate, with much organic matter. The two groups, although they may be alike structurally, are physiologically quite dissimilar, the chemical reactions involved in building the shells being of two different orders. Such a distinction ought to be significant to biologists, and it is for them to determine what it means. Geologically, however, we can see that the phosphatic brachiopods have probably played some part in the formation of phosphatic sediments, a function which is shared by vertebrate animals and some crustaceans.

\section{MOLLUSIŚ}

Numerous analyses of molluscan shells have been published, and they show remarkable uniformity of composition. It has nevertheless seemed desirable to make a liberal series of new analyses, which are best classified into groups. Sulphates were not determined, except in four analyses.

\section{PELECYPODS.}

The pelecypod shells analyzed are as follows:

1. Astarte crenata Gray. Off Marthas Vineyard, Mass; depth of water, 668 meters; bottom temperature, $7.2^{\circ} \mathrm{C}$.

2 Callista convexa Say. Vineyard Sound, Mass.

3. Macoma sabulosa Spengler. Massachusetts Bay; depth, 825 meters; bottom temperature, $5.5^{\circ} \mathrm{C}$.

4. Pecten dislocatus Say. Charlotte Harbor, Fla.

5. P'ecten ventricosus Sowerby. Head of Concepcion Bay, Lower California.

6. Venericardia ventricasa Gould. Off Point Conception, southern California: latitude, $34^{\circ} 25^{\prime} \mathrm{N}$.; depth, 447 meters; bottom temperature, $7.3^{\circ} \mathrm{C}$.

7. Cardium substriatum Conrad. Long Beach, Calif.

8. Calyplogena pacifica Dall. Clarence Strait. Alaska; latitude, $55^{\circ} 46^{\prime} \mathrm{N}$; depth, 589 meters; bottom temperature. $5.8^{\circ} \mathrm{C}$.

9. Nucula expanser Hancock. North of Bering Strait.

10. Acila mirabilis Adams and Reeve. Japan Sea, off the coast of Chosen (Korea); depth, 128 meters; bottom temperature, $16^{\circ} \mathrm{C}$.

11. Placuna orbicularis Retzius. Off Luzon, Philippine Islands.

3 Logan, W. E., and Hunt, T. S., Am. Jour. Sci., $2 \mathrm{~d}$ Ser., vol. 17, p. 237, 1854.

3 Hilger, A., Jour. prakt. Chemie, vol. 102, p. 41s, 1867.

3' Cloëz. S.. Jahresb. Chemie, 1859, p. 642; from L'Institut, 1859, p. 240. 
MOIJUUSKS.

Analyses of pelecypod shells.

\begin{tabular}{|c|c|c|c|c|c|c|c|c|c|c|c|}
\hline & $i$ & 2 & 3 & 4 & 5 & 6 & 7 & 8 & 9 & 10 & 11 \\
\hline 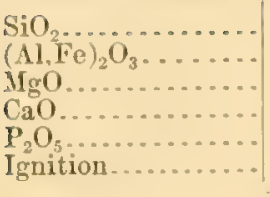 & $\begin{array}{r}0.25 \\
.08 \\
.00 \\
53.92 \\
\text { Trace. } \\
44.79\end{array}$ & $\begin{array}{r}0.18 \\
.11 \\
\text { Trace. } \\
53.67 \\
.03 \\
44.77\end{array}$ & $\begin{array}{r}0.29 \\
.22 \\
.00 \\
43.77 \\
\text { Trace. } \\
44.62\end{array}$ & $\begin{array}{r}0.31 \\
.08 \\
.46 \\
53.68 \\
\text { Trace. } \\
44.34\end{array}$ & $\begin{array}{r}0.14 \\
.15 \\
.34 \\
54.13 \\
\text { Trace. } \\
44.36\end{array}$ & $\begin{array}{r}0.12 \\
.05 \\
.00 \\
54.16 \\
\text { Trace. } \\
44.65\end{array}$ & $\begin{array}{r}0.11 \\
.09 \\
\text { Trace. } \\
53.99 \\
\text { Trace. } \\
\mathbf{4 4 . 8 5}\end{array}$ & $\begin{array}{r}0.08 \\
.04 \\
.00 \\
53.95 \\
\text { Trace. } \\
44.93\end{array}$ & $\begin{array}{r}0.33 \\
.46 \\
\text { Trace. } \\
51.18 \\
.17 \\
46.67\end{array}$ & $\begin{array}{r}0.09 \\
.08 \\
.00 \\
53.36 \\
\text { Trace. } \\
45.59\end{array}$ & $\begin{array}{r}0.00 \\
.08 \\
.32 \\
53.80 \\
\text { Trace. } \\
44.10\end{array}$ \\
\hline $\begin{array}{l}\mathrm{CO}_{2} \text { needed....... } \\
\text { Organic matter, etc. }\end{array}$ & $\begin{array}{r}99.04 \\
42.37 \\
2.42\end{array}$ & $\begin{array}{r}98.76 \\
42.10 \\
2.67\end{array}$ & $\begin{array}{r}98.90 \\
42.25 \\
2.37\end{array}$ & $\begin{array}{r}98.87 \\
42.69 \\
1.65\end{array}$ & $\begin{array}{r}99.12 \\
42.90 \\
1.46\end{array}$ & $\begin{array}{r}99.01 \\
42.55 \\
2.10\end{array}$ & $\begin{array}{r}99.04 \\
42.41 \\
2.44\end{array}$ & $\begin{array}{r}99.00 \\
42.39 \\
2.54\end{array}$ & $\begin{array}{r}98.81 \\
39.86 \\
6.81\end{array}$ & $\begin{array}{r}99.12 \\
41.93 \\
3.66\end{array}$ & $\begin{array}{r}98.30 \\
41.73 \\
2.37\end{array}$ \\
\hline
\end{tabular}

Reduced analyses of pelecypod shells.

\begin{tabular}{|c|c|c|c|c|c|c|c|c|c|c|c|}
\hline & 1 & 2 & 3 & 4 & 5 & 6 & 7 & 8 & 9 & 10 & 11 \\
\hline $\begin{array}{l}\mathrm{SiO} \\
\left(11, \mathrm{ICH}_{2}()_{3} \ldots \ldots \ldots\right. \\
\mathrm{I} \mathrm{gCO} \mathrm{O}_{3} \ldots \ldots \ldots \\
\mathrm{CaCO}_{3} \ldots \ldots \ldots \ldots \\
\mathrm{Ca}_{3} \mathrm{P}_{2} \mathrm{O}_{8} \ldots \ldots \ldots \ldots\end{array}$ & $\begin{array}{r}0.26 \\
.019 \\
.00 \\
99.65 \\
\text { Trace. }\end{array}$ & $\begin{array}{r}0.19 \\
.12 \\
\text { Trace. } \\
99.62 \\
.07\end{array}$ & $\begin{array}{r}0.30 \\
.23 \\
.00 \\
99.47 \\
\text { Trace. }\end{array}$ & $\begin{array}{r}0.32 \\
.05 \\
1.00 \\
98.60 \\
\text { Trace. }\end{array}$ & $\begin{array}{r}0.14 \\
.15 \\
.73 \\
98.98 \\
\text { Trace. }\end{array}$ & $\begin{array}{r}0.13 \\
05 \\
.00 \\
99.79 \\
\text { Trace. }\end{array}$ & $\begin{array}{r}0.11 \\
00 \\
\text { Trace. } \\
99.80 \\
\text { Trace. }\end{array}$ & $\begin{array}{r}0.09 \\
04 \\
.00 \\
99.87 \\
\text { Trace. }\end{array}$ & $\begin{array}{r}0.36 \\
.50 \\
\text { Trace. } \\
98.74 \\
.40\end{array}$ & $\begin{array}{r}0.10 \\
0.9 \\
00 \\
99.82 \\
\text { Trace. }\end{array}$ & $\begin{array}{r}0.00 \\
.05 \\
.70 \\
99.22 \\
\text { Trace. }\end{array}$ \\
\hline & 100.00 & 100.00 & 100.00 & 100.00 & 100.00 & 100.00 & 100.0 & 100.00 & 100.00 & 100.00 & 100.00 \\
\hline
\end{tabular}

\section{SCAPHOPODS AND AMPHINEURANS.}

Under this heading we have only two analyses to offer, as follows:

12. Dentalium solidum Verrill. Off Georges Bank, east of Cape Cod, Mass.; depth of water, 2,361 meters; bottom temperature, $4.5^{\circ} \mathrm{C}$.

13. Mopalia muscosa Gould. Santa Barbara, Calif. A chiton.

Analyses of scaphopods and amphineurans.

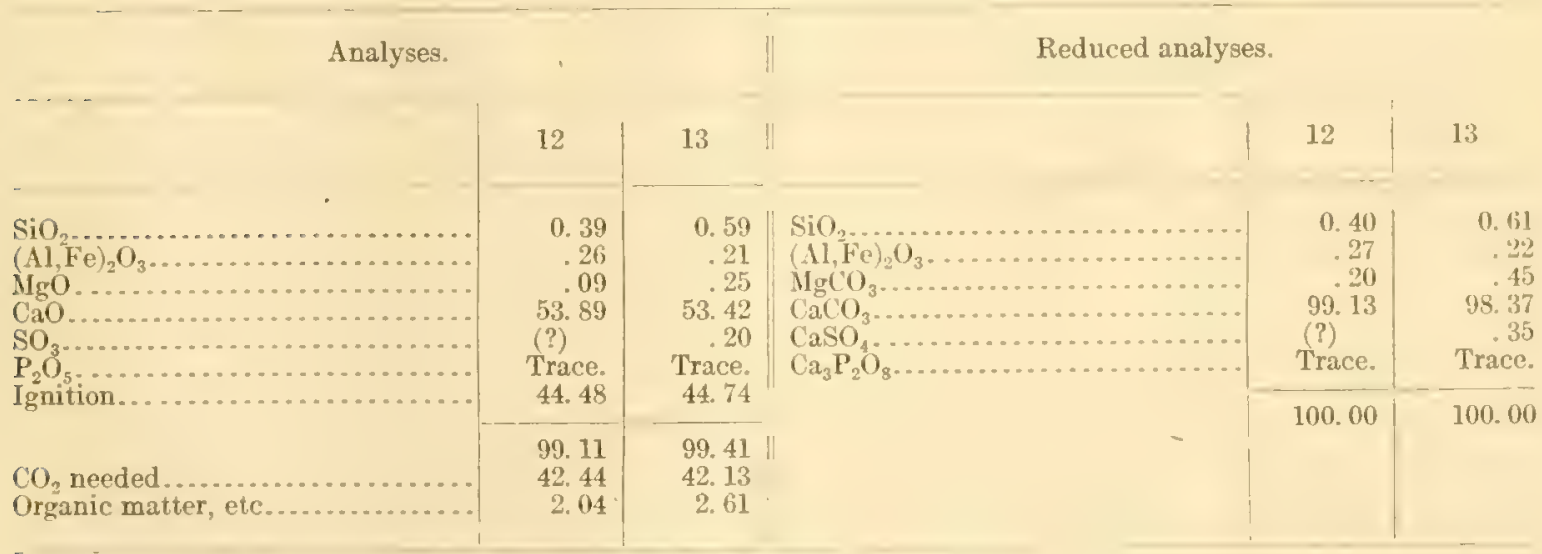

\section{GASTROPODS.}

14. T'urpura lapillus Linné. Eastport, Maine.

15. A porrhais occidentalis Beck. Off Marthas Vineyard, Mass.; depth of water, 435.5 meters; bottom temperature, $5.5^{\circ} \mathrm{C}$.

16. Buccinum undatum Linné. Narragansett Bay, IR. I.; depth, 53.3 meters; bottom temperature, $9^{\circ} \mathrm{C}$.

17. Natica duplicata Say. Cape Lookont, N. C.

18. Olivia literata Lamarck. Sarasota, Fla.

19. Fasciolaria distans Lamarck. Sarasota, I'la.

20. Crepidula onyx Sowerby. San Pedro, Calif.

21. Antiplanes perversa Gabb. Off Bodega Head, Calif, latitude, $38^{\circ}$ '23' $35^{\prime \prime} \mathrm{N}$; depth, 112.5 meters; bottorm temperature, $9^{\circ} \mathrm{C}$.

22. Nassa californiana Conrad. Monterey Bay, Calif.; Iatitude, $36^{\circ} 47^{\prime} 50^{\prime \prime} \mathrm{N}$.; depth, 67.7 meters; bottom ternperature, $11.3^{\circ} \mathrm{C}$. 
23. Nassa tegula Reeve. Musgrove Island, Magdalena Bay, Lower California.

24. Nassa insculpta Carpenter. Cortez Bank, Calif.; latitude, $32^{\circ} 20^{\prime} 30^{\prime \prime} \mathrm{N}$.; depth, 165 meters; bottom temperature, $9.5^{\circ} \mathrm{C}$

25. Turritella gonostoma Valenciennes. Mulege, Gulf of California.

26. Volutometra alaskana Dall. Off Unalaska, Alaska; latitude, $55^{\circ} \mathrm{N}$; depth, 143 meters; bottom temperature, $4.5^{\circ} \mathrm{C}$.

27. Pyrolofusus harpa Mörch. Unalaska, Alaska.

25. Plicifusus dirus Reeve. Sitka IIarbor, Alaska.

29. Tachyrhynchus erosa Couthouy. Avatcha Bay, Kamchatka.

30. Ranella pulchra Gray. China Sea, north of Prabas Island; depth, 256 meters; bottom temperature, $14.2^{\circ} \mathrm{C}$.

31. Cerithium aluco Linné. Reef opposite Cebu, Philippine Islands.

32. Strombus canarium Linne. Subig Bay, Luzon, Philippine Islands.

33. Carotina longirostris Lesueur. Off Adyagan Island, Philippine Islands; depth, 247 meters.

Analyses of gastropods.

\begin{tabular}{|c|c|c|c|c|c|c|c|c|c|c|}
\hline & 14 & 15 & 16 & 17 & 18 & 19 & 20 & 21 & 22 & 23 \\
\hline 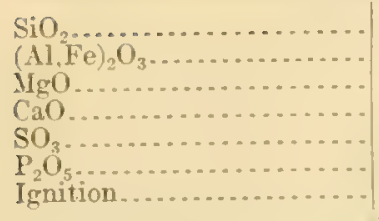 & $\begin{array}{c}0.14 \\
.15 \\
.19 \\
53.34 \\
(?) \\
\text { Trace. } \\
45.33\end{array}$ & $\begin{array}{r}1.27 \\
.22 \\
\text { Trace. } \\
52.84 \\
.08 \\
\text { Trace. } \\
41.09\end{array}$ & $\begin{array}{c}0.94 \\
.41 \\
.12 \\
52.77 \\
(?) \\
\text { Trace. } \\
44.49\end{array}$ & $\begin{array}{c}0.00 \\
.05 \\
\text { Trace. } \\
54.83 \\
(?) \\
\text { Trace. } \\
44.22\end{array}$ & $\begin{array}{c}0.05 \\
.04 \\
.00 \\
54.38 \\
(? ?) \\
\text { Trace. } \\
44.46\end{array}$ & $\begin{array}{c}0.33 \\
.04 \\
.06 \\
53.87 \\
\text { (?) } \\
\text { Trace. } \\
\text { 44. } 49\end{array}$ & $\begin{array}{r}0.15 \\
.11 \\
\text { Trace. } \\
53.63 \\
.00 \\
\text { Trace. } \\
44.40\end{array}$ & $\begin{array}{c}0.46^{\circ} \\
.11 \\
\text { Trace. } \\
54.06 \\
\text { (?) } \\
\text { Trace. } \\
44.15\end{array}$ & $\begin{array}{c}0.27 \\
.12 \\
.17 \\
53.20 \\
\text { (?) } \\
\text { Trace. } \\
44.81\end{array}$ & $\begin{array}{r}2.07 \\
.33 \\
.20 \\
51.30 \\
\text { (?) } \\
.08 \\
44.76\end{array}$ \\
\hline $\begin{array}{l}\mathrm{CO}_{2} \text { needed................ } \\
\text { Organic matter, etc....... }\end{array}$ & $\begin{array}{r}99.15 \\
42.12 \\
3.21\end{array}$ & $\begin{array}{r}98.50 \\
41.52 \\
2.57\end{array}$ & $\begin{array}{r}98.73 \\
41.59 \\
2.90\end{array}$ & $\begin{array}{r}99.10 \\
43.08 \\
1.14\end{array}$ & $\begin{array}{r}98.93 \\
42.73 \\
1.73\end{array}$ & $\begin{array}{r}98.79 \\
42.39 \\
2.10\end{array}$ & $\begin{array}{r}98.29 \\
42.14 \\
2.26\end{array}$ & $\begin{array}{r}98.78 \\
42.48 \\
1.67\end{array}$ & $\begin{array}{r}98.60 \\
41.99 \\
2.85\end{array}$ & $\begin{array}{r}95.74 \\
40.37 \\
4.39\end{array}$ \\
\hline & 24 & 25 & 26 & 27 & 28 & 29 & 30 & 31 & 32 & 33 \\
\hline 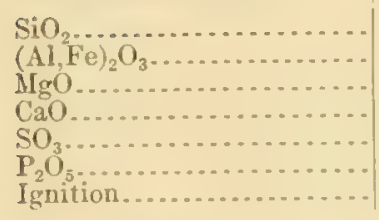 & $\begin{array}{r}0.47 \\
.47 \\
.77 \\
49.32 \\
(?) \\
.04 \\
48.00\end{array}$ & $\begin{array}{r}0.25 \\
1.83 \\
-20 \\
52.57 \\
.11 \\
\text { Trace. } \\
43.51\end{array}$ & $\begin{array}{c}0.07 \\
.17 \\
\text { Trace. } \\
53.88 \\
\text { (?) } \\
\text { Trace. } \\
44.60\end{array}$ & $\begin{array}{c}0.08 \\
.08 \\
\text { Trace. } \\
54.23 \\
(?) \\
\text { Trace. } \\
44.42\end{array}$ & $\begin{array}{c}0.16 \\
.22 \\
.11 \\
52.66 \\
(?) \\
\text { Trace. } \\
45.83\end{array}$ & $\begin{array}{r}0.23 \\
.81 \\
.44 \\
49.30 \\
(?) \\
47.36 \\
47.60\end{array}$ & $\begin{array}{c}2.20 \\
.61 \\
.23 \\
52.63 \\
\text { (?) } \\
\text { Trace. } \\
43.31\end{array}$ & $\begin{array}{r}0.00 \\
.09 \\
\text { Trace. } \\
54.47 \\
(?) \\
\text { Trace. } \\
44.37\end{array}$ & $\begin{array}{r}0.05 \\
.20 \\
\text { Trace. } \\
54.04 \\
(?) \\
\text { Trace. } \\
44.31\end{array}$ & $\begin{array}{r}0.71 \\
.39 \\
.09 \\
53.73 \\
(?) \\
.38 \\
43.82\end{array}$ \\
\hline $\begin{array}{l}\mathrm{CO}_{2} \text { needed................. } \\
\text { Organic matter, etc...... }\end{array}$ & $\begin{array}{r}99.07 \\
39.51 \\
8.49\end{array}$ & $\begin{array}{r}98.47 \\
41.46 \\
2.05\end{array}$ & $\begin{array}{r}98.72 \\
42.33 \\
2.27\end{array}$ & $\begin{array}{r}98.81 \\
42.61 \\
1.81\end{array}$ & $\begin{array}{r}95.95 \\
41.50 \\
4.33\end{array}$ & $\begin{array}{r}98.74 \\
38.51 \\
9.06\end{array}$ & $\begin{array}{r}98.98 \\
41.64 \\
1.67\end{array}$ & $\begin{array}{r}98.93 \\
42.80 \\
1.57\end{array}$ & $\begin{array}{r}98.63 \\
42.46 \\
1.85\end{array}$ & $\begin{array}{r}99.12 \\
\text { 11. } 96 \\
1.86\end{array}$ \\
\hline
\end{tabular}

Reduced analyses of gastropods.

\begin{tabular}{|c|c|c|c|c|c|c|c|c|c|c|}
\hline & 14 & 15 & 16 & 17 & 18 & 19 & 20 & 21 & 22 & 23 \\
\hline \multirow[t]{2}{*}{ 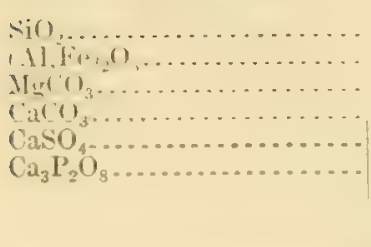 } & \begin{tabular}{c|}
0.15 \\
.16 \\
.41 \\
99.25 \\
$(?)$ \\
Trace.
\end{tabular} & \begin{tabular}{r|}
1.32 \\
.23 \\
Trace. \\
$9 S .30$ \\
.15 \\
Trace.
\end{tabular} & $\begin{array}{c}0.98 \\
.43 \\
.26 \\
98.33 \\
(?) \\
\text { Trace. }\end{array}$ & $\begin{array}{c}0.00 \\
.05 \\
\text { Trace. } \\
99.95 \\
\text { (?) } \\
\text { Trace. }\end{array}$ & $\begin{array}{c}0.05 \\
.04 \\
.00 \\
99.91 \\
(?) \\
\text { Trace. }\end{array}$ & $\begin{array}{c}0.34 \\
.04 \\
.14 \\
99.48 \\
(?) \\
\text { Trace. }\end{array}$ & $\begin{array}{r}0.16 \\
.11 \\
\text { Trace. } \\
99.73 \\
.00 \\
\text { Trace. }\end{array}$ & $\begin{array}{c}0.48 \\
.11 \\
\text { Trace. } \\
99.41 \\
(?) \\
\text { Trace. }\end{array}$ & $\begin{array}{c}0.28 \\
.13 \\
.37 \\
99.22 \\
(?) \\
\text { Trace. }\end{array}$ & $\begin{array}{r}2.19 \\
.35 \\
.44 \\
96.84 \\
\text { (?) } 18\end{array}$ \\
\hline & 100.00 & 100.00 & 100.00 & 100.00 & 100.00 & 100.00 & 100.00 & 100.00 & 100.00 & 100.00 \\
\hline & 24 & 25 & 26 & 27 & 28 & 29 & 30 & 31 & 32 & 33 \\
\hline \multirow[t]{2}{*}{ 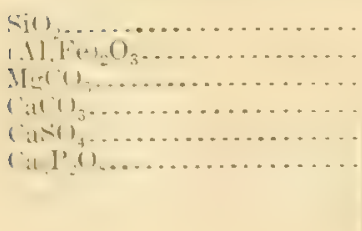 } & $\begin{array}{l}0.52 \\
.22 \\
1.25 \\
3114 \\
\because 10\end{array}$ & $\begin{array}{r}\text { (1. } 24 \\
1.49 \\
44 \\
37.21 \\
.20 \\
\text { Trace. }\end{array}$ & $\begin{array}{c}0.07 \\
.18 \\
\text { Trace. } \\
99.75 \\
(?) \\
\text { Trace. }\end{array}$ & $\begin{array}{c}0.08 \\
.08 \\
\text { Trace. } \\
99.84 \\
\text { (?) } \\
\text { Trace. }\end{array}$ & $\begin{array}{c}0.17 \\
.23 \\
.24 \\
99.36 \\
\text { (?) } \\
\text { Trace. }\end{array}$ & $\begin{array}{r}0.26 \\
.30 \\
1.02 \\
97.00 \\
(?) \\
.82\end{array}$ & $\begin{array}{c}2.26 \\
.63 \\
.51 \\
96.60 \\
(?) \\
\text { Trace. }\end{array}$ & $\begin{array}{c}0.00 \\
.10 \\
\text { Trace. } \\
99.90 \\
(?) \\
\text { Trace. }\end{array}$ & $\begin{array}{c}0.09 \\
.21 \\
\text { Trace. } \\
99.70 \\
\text { (?) } \\
\text { Trace. }\end{array}$ & $\begin{array}{r}0.73 \\
.40 \\
.20 \\
97.82 \\
(?) .85\end{array}$ \\
\hline & 100.00 & 100.110 & 100.00 & 100.00 & 100.00 & 100.00 & 100.00 & 100.00 & 100.00 & 100.00 \\
\hline
\end{tabular}




\section{CEPHALOPODS.}

34. Nautilus pompilius Iinne. Mindanao. Ithilippine Islands.

35. Argonmutr argo Linné; the paper nautilus. IHigh seas, I'acific Ocean.

36. Sepia sp; cuttlefish bone. Port Tataan, Tawi, Tawi group, Philippine Islands.

Inalyses of cephalopors.

\begin{tabular}{|c|c|c|c|}
\hline & 34 & 35 & 36 \\
\hline 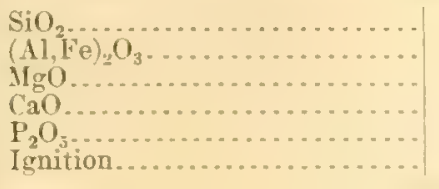 & $\begin{array}{r}0.18 \\
.14 \\
.07 \\
52.44 \\
\text { Trace. } \\
46.65\end{array}$ & $\begin{array}{r}0.08 \\
.12 \\
2.59 \\
46.78 \\
\text { Trace. } \\
49.16\end{array}$ & $\begin{array}{r}0.00 \\
.06 \\
.66 \\
47.42 \\
\text { Trace. } \\
51.63\end{array}$ \\
\hline 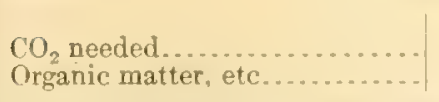 & $\begin{array}{r}99.48 \\
+1.28 \\
5.37\end{array}$ & $\begin{array}{r}98.72 \\
42.30 \\
6.86\end{array}$ & $\begin{array}{r}99.77 \\
38.65 \\
2.95\end{array}$ \\
\hline \multicolumn{4}{|c|}{ Reduced analyses of cephalopods. } \\
\hline & 34 & 35 & 36 \\
\hline \multirow[t]{2}{*}{ 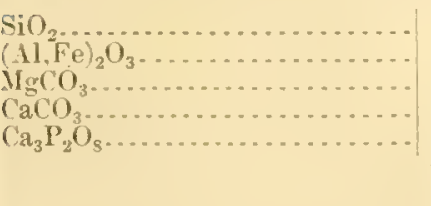 } & $\begin{array}{r}0.19 \\
.15 \\
.16 \\
99.50 \\
\text { Trace. }\end{array}$ & $\begin{array}{r}0.09 \\
.13 \\
6.02 \\
93.76 \\
\text { Trace. }\end{array}$ & $\begin{array}{r}0.00 \\
.06 \\
1.62 \\
98.32 \\
\text { Trace. }\end{array}$ \\
\hline & 100.00 & 100.00 & 100.00 \\
\hline
\end{tabular}

For comparison a series of four analyses of cephalopod shells by O. Bütschli ${ }^{36}$ is worth citing in full. They are as follows:

1. Nautilus pompilius. 2. Argonauta argo. 3. Spirula peronii. 4. Sepin officinalis.

Anrlyses of cephalopods by Bütschli.

\begin{tabular}{|c|c|c|c|c|}
\hline & I & 2 & 3 & 4 \\
\hline \multirow[t]{2}{*}{ 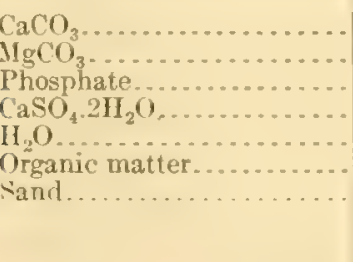 } & $\begin{array}{r}94.75 \\
.16 \\
.20 \\
2.62 \\
2.03 \\
\ldots .\end{array}$ & $\begin{array}{r}85.07 \\
5.08 \\
3.06 \\
1.75 \\
2.92 \\
2.43\end{array}$ & $\begin{array}{r}90.43 \\
.46 \\
3.20 \\
.48 \\
2.17 \\
2.32 \\
.32\end{array}$ & $\begin{array}{r}87.36 \\
.21 \\
2.26 \\
.78 \\
4.89 \\
5.36 \\
\end{array}$ \\
\hline & 99.76 & 100.31 & 99.39 & 100.86 \\
\hline
\end{tabular}

Exactly what is meant by "phosphate" is not clear. Assuming it to mean calcium phosphate and reducing the analyses to uniformity with ours, they take the following form:

Bütschli's rnalyses reduced.

\begin{tabular}{|c|c|c|c|c|}
\hline \multirow{3}{*}{ 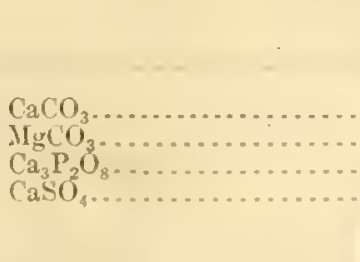 } & 1 & 2 & 3 & 4 \\
\hline & $\begin{array}{r}99.66 \\
.17 \\
.17\end{array}$ & $\begin{array}{l}89.93 \\
5.37 \\
3.24 \\
1.46\end{array}$ & $\begin{array}{r}95.75 \\
.48 \\
3.39 \\
.38\end{array}$ & $\begin{array}{r}96.58 \\
.13 \\
2.50 \\
.69\end{array}$ \\
\hline & 100.00 & 100.00 & 100.00 & 100.00 \\
\hline
\end{tabular}

36 Butschli, O., K. Gesell. Wiss. Göttingen Abh., No. 3, 1908. Butschli also gives analyses of three other mollusks, I'inna japonica, I'afella vulgula, and Purpure lapillus, but they show no unusual features. 
The unusual proportion of magnesium carbonate in Argonauta is confirmed by our analysis, but the high phosphate in three of Butschli's analyes is unlike anything in our series. Possibly the calcium sulphate is really present in the hydrated form, that is, as gypsum, but that is uncertain. However, it is not necessary to make that assumption, and to do so would complicate the comparison of analyses.

From the evidence now at hand and from many older data it is clear that molluscan shells consist almost entirely of calcium carbonate with quite insignificant impurities. The only notable exception is Argonauta, which contains 6 per cent of magnesium carbonate, but the paper nautilus has no importance as a contributor to the marine sediments. The mollusks generally are of immense importance, a fact to which their fossil remains abundantly testify. In composition they resemble the corals and millepores, so much so that an analysis from one group might readily pass for an analysis from another ${ }^{37}$

\section{CRUSTACEANS.}

The 19 crustaceans analyzed in the course of this investigation fall into two distinct groups. First, the barnacles, which have shells composed mainly of calcium carbonate with very little organic matter. Second, a group of the more familiar crustaceans, such as crabs, shrimps, and lobsters. These have shells containing notable amounts of calcium phosphate and much organic matter. The analyses of the first group cover the following species:

1. Lepas anatifera Linné. Florida.

2. Lepas anserifera Iinné. Woods Hole, Mass.

3. Mitella polymerus Sowerby. Pacific Grove, Calif.; latitude, $36^{\circ} 36^{\prime} \mathrm{N}$.; longitude, $121^{\circ} 55^{\prime}$ IV.

4. Balanus hameri Ascanius. Georges Bank, east of Cape Cod, Mass.

5. Balanus amphitrite niveres Darwin. Cape May, N. J.

6. Balanus eburneus Gould. Smiths Creek. Potomac River, Md.

7. Scalpellum regium Wyville Thomson and Hoek. Albutross station 3342; off Queen Charlotte Islands; latitude, $52^{\circ} 39^{\prime} 30^{\prime \prime} \mathrm{N}$.; longitude, $132^{\circ} 35^{\prime} \mathrm{W}$; d depth of water, 2,906 meters; bottom temperature, $1.8^{\circ} \mathrm{C}$.

The analyses are as follows:

Analyses of barnacles.

\begin{tabular}{|c|c|c|c|c|c|c|c|}
\hline & 1 & 2 & 3 & 4 & 5 & 6 & 7 \\
\hline 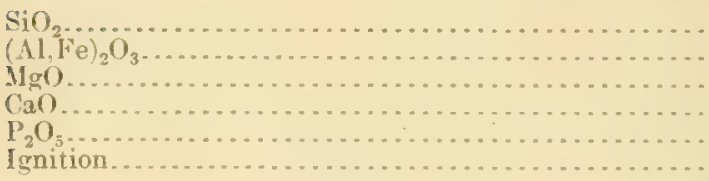 & $\begin{array}{r}0.01 \\
.19 \\
1.14 \\
52.33 \\
\text { Trace. } \\
44.50\end{array}$ & $\begin{array}{r}0.01 \\
.56 \\
.86 \\
52.53 \\
\therefore .34 \\
43.90\end{array}$ & $\begin{array}{r}0.08 \\
.30 \\
.91 \\
50.83 \\
\text { Trace. } \\
16.18\end{array}$ & $\begin{array}{r}0.03 \\
.14 \\
.35 \\
53.57 \\
.00 \\
41.39\end{array}$ & $\begin{array}{r}1.99 \\
.68 \\
.73 \\
50.09 \\
\text { Trac.. } \\
+1.84\end{array}$ & $\begin{array}{r}0.39 \\
.22 \\
.76 \\
53.23 \\
\text { Trace. } \\
11.28\end{array}$ & $\begin{array}{r}0.73 \\
1.03 \\
52.65 \\
\text { Trace. } \\
\text { 11. } 7 !\end{array}$ \\
\hline 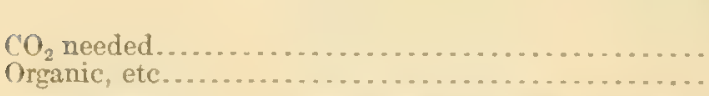 & $\begin{array}{r}93.20 \\
+2.37 \\
2.13\end{array}$ & $\begin{array}{r}98.23 \\
41.82 \\
2.08\end{array}$ & $\begin{array}{r}98.33 \\
40.97 \\
5.21\end{array}$ & $\begin{array}{r}98.48 \\
42.47 \\
1.92\end{array}$ & $\begin{array}{r}98.33 \\
40.16 \\
4.68\end{array}$ & $\begin{array}{r}98.88 \\
42.67 \\
1.61\end{array}$ & $\begin{array}{r}99.20 \\
42.48 \\
2.31\end{array}$ \\
\hline
\end{tabular}

Liedued amulyses of barnurlfs.

\begin{tabular}{|c|c|c|c|c|c|c|c|}
\hline & 1 & 2 & 3 & 4 & 5 & 6 & 7 \\
\hline \multirow[t]{2}{*}{ 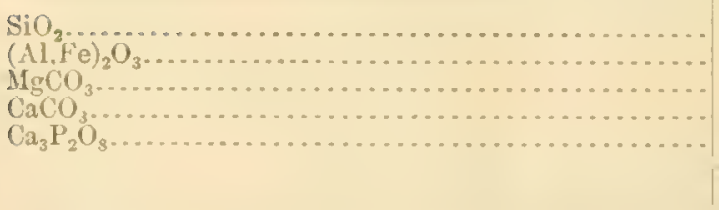 } & $\begin{array}{r}0.04 \\
.20 \\
2.49 \\
97.27 \\
\text { Trace. }\end{array}$ & $\begin{array}{r}0.04 \\
.58 \\
1.87 \\
96.74 \\
.77\end{array}$ & $\begin{array}{r}0.09 \\
.33 \\
2.11 \\
97.47 \\
\text { Trace. }\end{array}$ & $\begin{array}{r}0.03 \\
.15 \\
.75 \\
99.07 \\
.00\end{array}$ & $\begin{array}{r}2.12 \\
.72 \\
1.63 \\
95.53 \\
\text { Trace. }\end{array}$ & $\begin{array}{r}0.40 \\
.22 \\
1.65 \\
97.73 \\
\text { Trace. }\end{array}$ & $\begin{array}{r}0.75 \\
2.23 \\
97.02 \\
\text { Trace. }\end{array}$ \\
\hline & 100.00 & 100.00 & 100.00 & 100.00 & 100.00 & 100.00 & 100.00 \\
\hline
\end{tabular}

37 For additional data see Schmelck, L., Norske Nordhsrs Exped., No. 28, p. 129, 1901 . Fourteen anal rses of molluscan shells are given, of the genera Buccinum, Astarte, Neplunea, and l'cten, all from the North Sea. The highest percentage of magnesium carbonste found was 0.78, the lowest 0.26. For ten complete analy'ses of oyster shells see Chatio, A., snd Muntz, A., Compt. Rend., vol.120, p. 531, 1595. For eleven analyses of land shells see an inaugural dissertation by A. Döring, Göttingen, 1872 . Several determinations of maguesium carbonate, maximum 1 per cent, are given by G. Forchhammer in Neues Jahrb., 1852, p. 85 . 
Sulphates and soluble salts were not determined. Except for the slightly higher magnesia, these analyses closely resemble those of mollusks.

One analysis of a barnacle, Balanus tintinnabulus, by Bütschli, ${ }^{38}$ is essentinlly similar to ours.

His figures are-

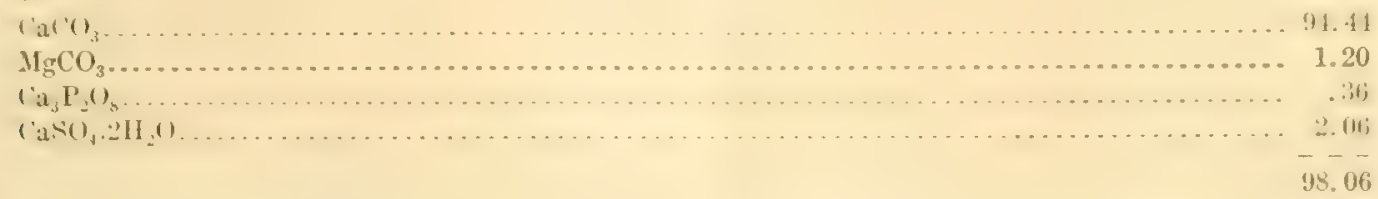

In all the analyses calcium carbonate is the main constituent, and there are only minor impurities. We hare found no other analysis of a barnacle recorded.

In the second group of crustaceans the following species were analyzed:

1. Tryphosa pinguis Boeck; sand flea. Woods Hole, Mass.

2. Pagurus rathbuni Benedict; hermit crab. Bering Sea, Albatross station 3531 : latitude, $50^{\circ} 55^{\prime}$ N.: longitude, $174^{\circ} 17^{\prime} \mathrm{W}$; depth of water, 105 meters; bottom temperature, $1.7^{\circ} \mathrm{C}$

3. Callinectes sapidus M. J. Rathbun; blue crab. Ranges from Cape Cod to Florida.

4. Homanus americanus Milne-Edwards; common lobster. Vineyard Sound, Mass.

5. Pandalus platyceros Brandt; shrimp. Off Mfonterey Bay, Calif.; Albatross station 3129; latitude, $36^{\circ} 39^{\prime} 40^{\prime \prime}$ $\mathrm{N}$.; longitude, $122^{\circ} 01^{\prime} \mathrm{W}$; depth, 49.4 meters; bottom temperature, $6.5^{\circ} \mathrm{C}$.

6. Lithodes maia Linne; spider crab. North Atlantic coast, precise locality of specimen unknown.

7. Libinia emarginata Leach; spider crab. Vineyard Sound, Mass.

8. Munida iris Milne-Edwards; long-armed munida. Off Chesapeake Bay; Albatross station 2420; latitude, $37^{\circ}$ $03^{\prime} 20^{\prime \prime} \mathrm{N}$.; longitude, $74^{\circ} 31^{\prime} 40^{\prime \prime} \mathrm{W}$.; depth, 190.3 meters; bottom temperature, $8.7^{\circ} \mathrm{C}$.

9. Crago dalli Rathbun; a shrimp. Off Cape Strogonof, Alaska; Albatross station 329.1; latitude, $57^{\circ} 16^{\prime} 45^{\prime \prime} \mathrm{N}$.; longitude, $159^{\circ} 03^{\prime} 30^{\prime \prime} \mathrm{W}$; depth, 54.9 meters: bottom temperature, $5^{\circ} \mathrm{C}$.

10. Panulims argus Latreille; spiny lobster. West Indies.

11. Chloridella empusa Say; mantis shrimp. Ranges from Cape Cod to Florida.

12. Eriphir sebana (Shaw). Chance Island, Mergui Archipelago, off coast of Tenasserim, Lower Burma. Latitude about $10^{\circ} \mathrm{N}$. A crab.

13. Grapsus grapsus tenuicrustatus (Herbst). Aldabra Islands, Indian Ocean; Iatitude, $9^{\circ} 26^{\prime}$ S.; longitude, $46^{\circ}$ 35 ' E. A crab.

Analyses 12, 13 by B. Salkover.

14. Penaeus brasiliensis Latreille; edible shrimp. Ranges from New York to Brazil.

Analyses of crustaceans.

\begin{tabular}{|c|c|c|c|c|c|c|}
\hline & 1 & 2 & 3 & 5 & 6 & 7 \\
\hline 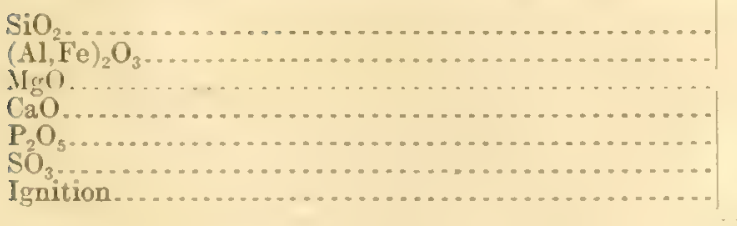 & $\begin{array}{r}0.62 \\
.37 \\
1.27 \\
28.63 \\
4.56 \\
.23 \\
64.73\end{array}$ & $\begin{array}{r}0.16 \\
.15 \\
1.1 .3 \\
29.11 \\
3.25 \\
.75 \\
64.50\end{array}$ & $\begin{array}{r}0.04 \\
.04 \\
2.06 \\
3.42 \\
4.26 \\
.23 \\
8.89\end{array}$ & $\begin{array}{r}0.32 \\
.26 \\
1.44 \\
18.56 \\
4.60 \\
73.54\end{array}$ & $\begin{array}{r}0.00 \\
.15 \\
1.90 \\
24.15 \\
3.51 \\
.63 \\
69.00\end{array}$ & $\begin{array}{r}2.61 \\
.78 \\
2.81 \\
32.79 \\
2.73 \\
57.49 \\
57.07\end{array}$ \\
\hline $\begin{array}{l}\mathrm{CO}_{2} \text { needed } \ldots \ldots \ldots \ldots \ldots \ldots \ldots \ldots \ldots \ldots \ldots \ldots \ldots \ldots \ldots \\
\text { Organic matter, etc } \ldots \ldots \ldots \ldots \ldots \ldots \ldots \ldots \ldots\end{array}$ & $\begin{array}{r}100.41 \\
19.53 \\
45.20\end{array}$ & $\begin{array}{l}99.47 \\
21.14 \\
43.36\end{array}$ & $\begin{array}{l}98.94 \\
24.43 \\
34.46\end{array}$ & $\begin{array}{l}99.53 \\
11.58 \\
62.23\end{array}$ & $\begin{array}{l}99.34 \\
17.46 \\
51.54\end{array}$ & $\begin{array}{l}99.28 \\
26.05 \\
31.02\end{array}$ \\
\hline & 8 & 9 & 10 & 11 & 12 & 13 \\
\hline 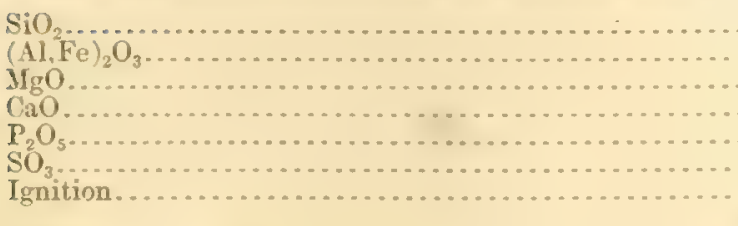 & $\begin{array}{r}0.32 \\
.16 \\
2.58 \\
31.28 \\
1.87 \\
62.47\end{array}$ & $\begin{array}{r}0.62 \\
.20 \\
1.01 \\
9.95 \\
2.65 \\
.47 \\
83.70\end{array}$ & $\begin{array}{r}0.16 \\
.13 \\
3.15 \\
25.36 \\
2.09 \\
.41 \\
66.69\end{array}$ & $\begin{array}{r}0.02 \\
.17 \\
2.60 \\
15.38 \\
7.75 \\
1.07 \\
72.35\end{array}$ & $\begin{array}{r}\text { Trace. } \\
4.82 \\
1.19 \\
34.20 \\
3.38 \\
\text { Trace. } \\
53.92\end{array}$ & $\begin{array}{r}\text { Trace. } \\
4.73 \\
1.57 \\
25.30 \\
2.98 \\
\text { Trace. } \\
64.87\end{array}$ \\
\hline $\mathrm{CO}_{2}$ needed.... & $\begin{array}{l}98.97 \\
25.41 \\
36.85\end{array}$ & $\begin{array}{r}98.60 \\
6.20 \\
77.50\end{array}$ & $\begin{array}{l}97.99 \\
21.23 \\
45.46\end{array}$ & $\begin{array}{r}99.34 \\
7.15 \\
65.20\end{array}$ & $\begin{array}{l}97.51 \\
25.04 \\
28.88\end{array}$ & $\begin{array}{l}99.45 \\
18.83 \\
47.79\end{array}$ \\
\hline
\end{tabular}

\$ Bütschli, O., K. Gesell. Wiss. Göttingen Abh., No. 3, $190 \mathrm{~s}$. 
In No. 14, the common edible shrimp of the Washington (D. C.) markets, the shell was so thin that the arailable material was too small for complete analysis. Only $\mathrm{P}_{2} \mathrm{O}_{5}, 3.07$ per cent, was determined.

Reduced analyses of crustaceans.

\begin{tabular}{|c|c|c|c|c|c|c|c|}
\hline & 1 & 2 & 3 & 4 & 5 & 6 & 7 \\
\hline \multirow[t]{3}{*}{$\begin{array}{l}\mathrm{SiO}_{2} \ldots \ldots . . . \\
\left(\mathrm{Al}_{3} \mathrm{Fe}_{2} \mathrm{O}_{3}\right. \\
\mathrm{MgCO}_{3} \ldots \ldots \\
\mathrm{CaCO}_{3} \ldots \ldots \\
\mathrm{Ca}_{3} \mathrm{P}_{2} \mathrm{O}_{8} \ldots \\
\mathrm{CaSO}_{4} \ldots \ldots\end{array}$} & $\begin{array}{r}1.12 \\
.67 \\
4.84 \\
74.64 \\
18.02 \\
.71\end{array}$ & \begin{tabular}{r|}
0.28 \\
.27 \\
5.80 \\
78.03 \\
13.55 \\
2.07
\end{tabular} & $\begin{array}{r}0.06 \\
.06 \\
6.69 \\
78.14 \\
14.45 \\
.60\end{array}$ & $\begin{array}{r}0.00 \\
.31 \\
80.2 \\
79.50 \\
10.91 \\
1.23\end{array}$ & \begin{tabular}{r|}
0.87 \\
.70 \\
8.09 \\
60.94 \\
26.94 \\
2.46
\end{tabular} & $\begin{array}{r}0.00 \\
.31 \\
8.35 \\
73.07 \\
16.03 \\
2.24\end{array}$ & $\begin{array}{r}3.82 \\
1.14 \\
8.65 \\
76.44 \\
8.73 \\
1.22\end{array}$ \\
\hline & 100.00 & 100.00 & 100.00 & 100.00 & 100.00 . & 100.00 & 100.00 \\
\hline & 8 & 9 & 10 & 11 & & 12 & 13 \\
\hline \multirow[t]{2}{*}{ 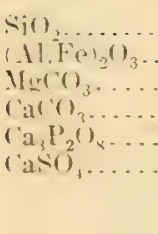 } & $\begin{array}{r}0.52 \\
.27 \\
8.71 \\
82.64 \\
6.57 \\
1.29\end{array}$ & $\begin{array}{r}2.94 \\
.95 \\
10.05 \\
54.83 \\
27.44 \\
3.79\end{array}$ & $\begin{array}{r}0.31 \\
.25 \\
12.58 \\
76.87 \\
8.68 \\
1.31\end{array}$ & & $\begin{array}{l}0.06 \\
.50 \\
5.99 \\
8.56 \\
9.56 \\
5.33\end{array}$ & $\begin{array}{r}\text { Trace. } \\
7.02 \\
3.65 \\
78.58 \\
10.75 \\
\text { Trace. }\end{array}$ & $\begin{array}{r}\text { Trace. } \\
8.86 \\
6.18 \\
72.77 \\
12.19 \\
\text { Trace. }\end{array}$ \\
\hline & 100.00 & 100.00 & 100.00 & & 0.00 & 100.00 & 100.00 \\
\hline
\end{tabular}

In addition to the foregoing analyses two more were made by Mr. Salkover of very minute crustaceans, such as form a large part of the marine plankton. Two samples, each made up of hundreds of individuals, were obtained from the U. S. National Museum, as follows:

1. Temora longicomis (O.F. Müller), from the coast of New England. Weight of dried sample, 0.6105 gram. A copepod. shrimp.

2. Thysanoessa inermis (Kroyer), from Balena, Newfoundland. Weight of dried sample, 1.5973 grams. A small

As the amount of material was insufficient for a thorough analysis, only three determinations were made on each sample. They were: Loss on ignition, mainly organic matter and water; phosphoric oxide; and residue insoluble in acid. The phosphoric oxide, $\mathrm{P}_{2} \mathrm{O}_{5}$, was recalculated into the form of tricalcic phosphate, $\mathrm{Ca}_{3} \mathrm{P}_{2} \mathrm{O}_{8}$, and with that adjustment the analyses assume the following shape:

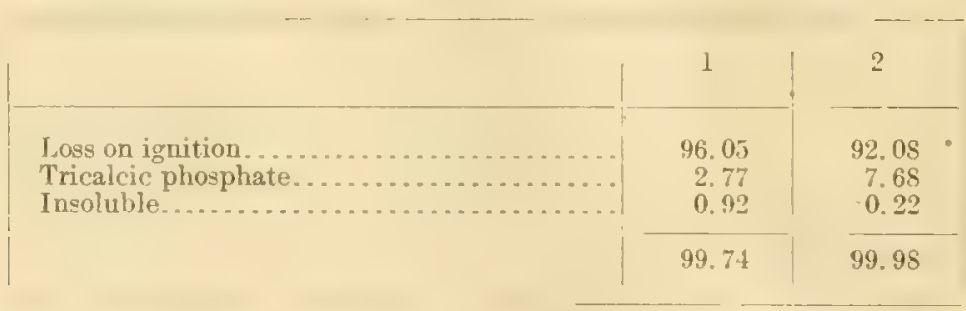

'These analyses show that the inorganic matter of these minute creatures consists almost entirely of calcium phosphate, although more refined analyses on larger quantities of material would doubtless show small percentages of other things. So far, however, it seems that these very small organisms effect what is perhaps a primary concentration of the traces of phosphorus that exist in sea water, and so, as food for the larger animals, they furnish the material from which the skeletons of marine vertebrates are built. It is a familiar fact that vertebrate skeletons consist largely, although not exclusively, of calcium phosphate. 
With the exception of the barnucles the analyses of crustacenns show that they are definitely phosphatic, a fact that was already well known. They are also magnesinn, another fact that in nearly all previous analyses had eithex been neglected or overlooked. 'The magnesia, however, shows no such regularity with regard to temperature as has been established by our analyses of alcyonarians and echinoderms. Eriphiu, for example, a tropical form, is abnormally low in magnesia; whereas Chloridella, also from warm water, is remarkably high. In other analyses the proportion of magnesium carbonnte appenrs to be about normal, but unfortunately the records for some specimens are defective as to precise localities and temperatures. Furthermore, the large amounts of organic matter and water render the reduced analyses to some extent unsatisfactory. This is especially true of analysis No. 9, in which the inorganic portion amounted to only 21 per cent. In reducing such an analysis the unaroidable analytical errors are multiplied, and the percentages of magnesium carbonate, calcium carbonate, and calcium phosphate may be uncertain by as much as 1 per cent each. In no case is the order of magnitude seriously changed, but the accuracy of the figures is not what we should wish it to be.

The irregularities in the magnesian content of the crustaceans led to a suspicion that they might be partly due to differences in the age or maturity of the specimens that were analyzed. In order to test this supposition we obtained, through the kindness of Dr. H. M. Smith, Director of the United States Bureau of Fisheries, the large claws of two lobsters (Homarus) taken at the station at Boothbay Harbor, Maine. One specimen was from a small lobster, the other from a large one, but the actual size of each lobster was not given. The analyses, by George Steiger, were as follows:

Analyses of lobster clau's.

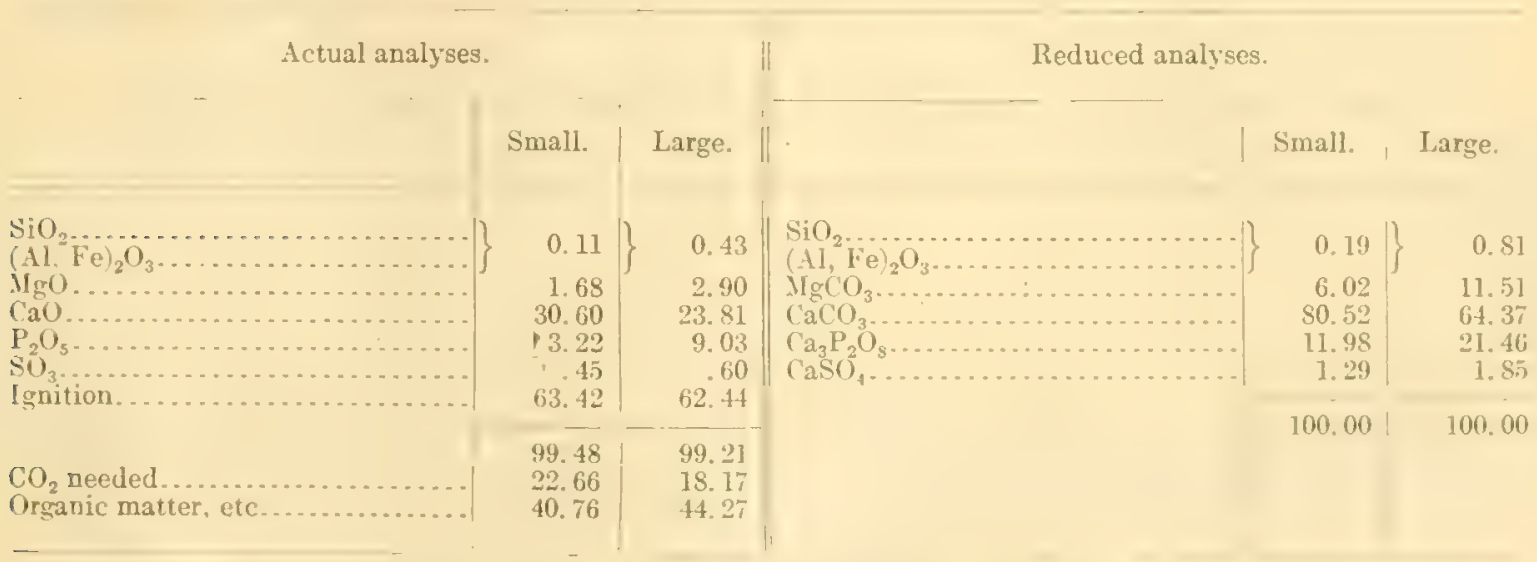

The differences between these two analyses are very striking and confirmed our first suspicion. In order to make the investigation more precise, Dr. Smith had sent us from the sume locality. Boothbay Harbor, parts of three lobsters; one small. one medium, and one large. The actual figures for each entire lobster were as follows:

1. Small lobster: Length, $8 \frac{1}{2}$ inches; weight, 10 ounces.

2. Jedium lobster: Length, $11 \frac{1}{2}$ inches; weight, 2 pounds

3. Large lobster: Length, $16 \frac{1}{2}$ inches; weight, $5 \frac{1}{2}$ pounds.

Furthermore, for each lobster a large claw and part of the carapace was supplied, so that for each animal two analyses could be made. This last precaution was taken because it was remembered that in two sea urchins it was found that the spines and the shell differed in composition. Is̀ an analogous difference between two parts of the same animal to be found among the crustaceans? 
The analyses, by Mr. Steiger, are as follows:

Analyses of lobster shells.

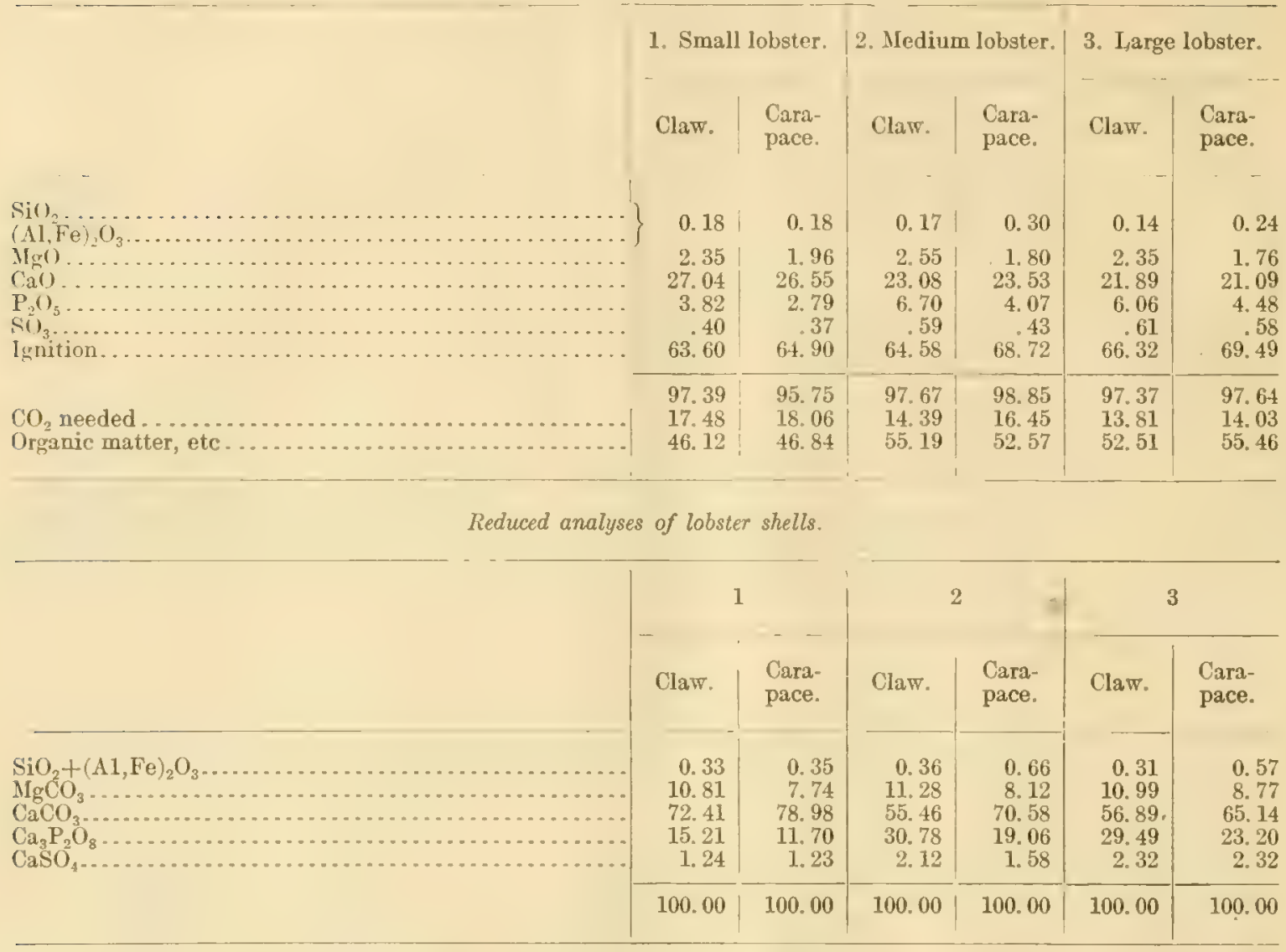

Here again our suspicions were verified. In each case the large claw is more highly magnesian and phosphatic than the carapace, and the increase in manesia and phosphorus in passing from youth to age is manifested. This last variation is more clearly shown by averaging together the two analyses for each lobster, as follows:

Average analyses of lobster shells.

\begin{tabular}{|c|c|c|c|}
\hline & 1. Small. & 2. Medium. & 3. Large. \\
\hline 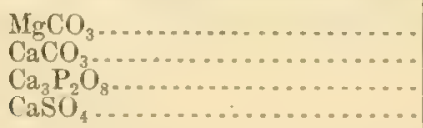 & $\begin{array}{r}9.27 \\
75.69 \\
13.45 \\
1.24\end{array}$ & $\begin{array}{r}9.70 \\
68.02 \\
24.92 \\
1.85\end{array}$ & $\begin{array}{r}9.88 \\
61.01 \\
26.35 \\
2.32\end{array}$ \\
\hline
\end{tabular}

It is also worth noting that the proportion of calcium sulphate increases regularly, which indicates that it is a definite constituent of the lobster shells and not a mere impurity.

From these variations in the composition of lobster shells, all from a single locality, it seems clear that in any future investigation of the same sort relative to crustaceans samples of the entire shells should be analyzed and only adult specimens should be studied. Only under such conditions will it be possible to determine whether regularities exist like those which have been observed in other series of organisms. 
The older analyses of the shells of crustaceans are more or less unsutisfactory, but they all agree as to the phosphatic character of these organisms. C. Schmidt, ${ }^{33}$ for example, gives three analyses, as follows:

1. Astacus fluriatilis: fresh-water crawfish. 53.27 per cent inorranic.

2. Lobster; probably either Ifomarus vulgaris or P'alinurus. 77.06 per cont inorganic.

3. Squillu manlis: a shrimp. 37.17 per cent inorganic.

Schmidt's analyses of crustaceans.

\begin{tabular}{|c|c|c|c|}
\hline & 1 & 2 & 3 \\
\hline \multirow[t]{2}{*}{ 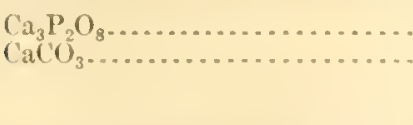 } & $\begin{array}{l}\text { 13. } 17 \\
86.83\end{array}$ & $\begin{array}{l}12.06 \\
87.94\end{array}$ & $\begin{array}{l}47.52 \\
52.08\end{array}$ \\
\hline & 100.00 & 100.00 & 100.00 \\
\hline
\end{tabular}

The figures given here are for the inorganic matter alone. Schmidt mentions magnesium phosphate as present but gives no determinations of it.

Two analyses of crustacean shells by E. Fremy ${ }^{40}$ are also worth citing:

1. "Langouste"; Palinurus vulgaris.

2. "Ecrevisse"; probably the crawfish, Astacus fluviatitis,

Fremy's analyses of crustaceans.

\begin{tabular}{|c|c|c|}
\hline & 1 & 2 \\
\hline \multirow[t]{2}{*}{ 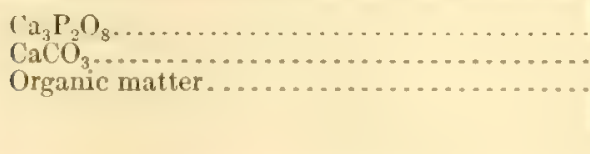 } & $\begin{array}{l}\text { 1i. } . \\
49.0 \\
44.3\end{array}$ & $\begin{array}{l}\text { li. }: \\
56.8 \\
\text { 36. } 5\end{array}$ \\
\hline & 100.0 & 100.0 \\
\hline
\end{tabular}

Here, again, the determination of magnesia has been neglected. If we reject the organic matter, the percentages of calcium phosphate in the inorganic part of the shells become 12.03 and 10.55 , respectively.

Astacus fluviatilis seems to have received more attention from chemists than any other crustacean. H. Weiske ${ }^{41}$ found in fresh shells 4.97 to 5.31 per cent of calcium phosphate and in old shells, partly cast off, 9.16 to 9.21 per cent. In "Krebsteine," the concretions found in the shells, the percentages ran from 10.73 to 11.28 per cent. The total inorganic matter raried between 61 and 67 per cent.

Astacus has also been. studied by Agnes Kelly, ${ }^{42}$ who also analyzed a myriapod, Julus (Iulus). Her figures are as follows:

Analyses by Agnes Kelly.

\begin{tabular}{|c|c|c|}
\hline & Astacus. & Julus. \\
\hline $\begin{array}{l}\mathrm{C}{ }_{2} \mathrm{O} \\
\mathrm{CO}_{2} \mathrm{O}_{2} \\
\mathrm{P}_{2} \mathrm{O}_{8}{ }_{2} \ldots \ldots\end{array}$ & $\begin{array}{r}30.44 \\
21.23 \\
2.79\end{array}$ & $\begin{array}{r}36.29 \\
21.60 \\
3.37\end{array}$ \\
\hline & 54.52 & 56. 26 \\
\hline
\end{tabular}

29 Schmidt, C., Annalen Chemie u. I'harm., vol. 5t, p. 303, 1845.

10 Fremy, E., Annales chimie ot phys., 3d ser., vol. 43, p. 94, 1555. Fremy alsogives many analyses of rertebrate liones, both recent anulfossil.

4) Weiske, H., Landwirthschaftliche Versuchsstationen, vol. 20, p. 45, 157t.

1: Kelly, Agoes, Jenaisches Zeitschr., rol. 35, p. 429, 1901 $106135-22-1$ 
In an analysis of Astacus fuviatilis by $\mathrm{O}$. Bütschli ${ }^{43}$ magnesia was actually determined. We append his analysis, together with our own reduction of it:

$$
\text { Bütschli's analysis of Astrcus. }
$$

$$
\text { Actual analysis. } \quad \text { Reduced analysis. }
$$

\begin{tabular}{|c|c|c|c|}
\hline \multirow{2}{*}{ 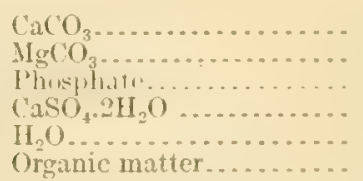 } & \multirow[t]{2}{*}{$\begin{array}{r}47.51 \\
1.38 \\
1 ; .7 \\
1.66 \\
1.34 \\
40.60\end{array}$} & \multirow[t]{3}{*}{ 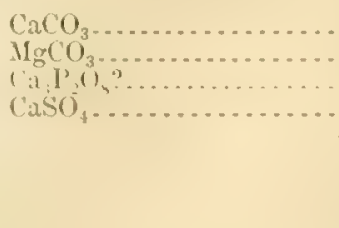 } & $\begin{array}{r}\text { 83. } 40 \\
\text { 2. } 42 \\
11.45 \\
2.30\end{array}$ \\
\hline & & & 100.00 \\
\hline & & & \\
\hline
\end{tabular}

In this analysis the low percentage of magnesia is rery significant. Astacus is a fresh-water crustacean, whereas the analyses in our series are all of marine forms. In fresh water-the average river water - calcium is 6 times as abundant as magnesirm, but in ocean water magnesium is $3 \frac{1}{2}$ times as abundant as calcium. This difference in the environment may possibly explain the difference between the fluriatile and the marine shells, 2.42 per cent of $\mathrm{MgCO}_{3}$ in one and 4.84 per cent in the lowest of our determinations.

One more determination of phosphoric oxide in a crustacean remains to be noted. In the shell of a lobster, Homarus vulgaris, W. H. Hudleston ${ }^{4 t}$ found 3.26 per cent of $\mathrm{P}_{2} \mathrm{O}_{5}$. This is equivalent to 7.12 per cent of $\mathrm{Ca}_{3} \mathrm{P}_{2} \mathrm{O}_{8}$, or, if the organic matter was about the same in amount as in our analysis of the American lobster, 11.44 per cent in the inorganic portion alone. 'This is not far from the figure giren in our reduced analysis No. 4, namely, 10.91 per cent.

Although the crustaceans are not of great importance as contributors to the marine sediments, they are more important than appears at a casual glance. A crab or lobster sheds its shell annually and grows a new one, so that an old indiridual has contributed many times. A single shell might count for little, but when multiplied by a dozen or more the contributions become significant. How significant they may be is for zoologists to determine.

\section{CAI,C\REOUS ALG $\triangle$ E.}

The calcareous algae are so important as reef builders that, although they are not marine invertehrates in the ordinary acceptance of the term, it seemed eminently proper to include them in this investigation. In many places they far outrank the corals in importance, and of late years much attention has been paid to them. To Dr. Marshall $\Lambda$. Howe, of the New York Botanical Garden, we are indebted for a fine series of alga, and to him we express our thanks.

For the purposes of this research the calcareous algre fall into two groups. One of these, of which Lithothamnium is the most familiar example, is highly magnesian; the other, represented by Halimeda, is almost free from magnesia. These groups are best considered separately, and under the first one we have the following species:

1. Lithothamnium glaciale Kjellman. Topsail, Conception Bay, Newfoundland; latitude, $45^{a}$ N.; longitude,

2. Lithothamnium erubescens Foslie. IJaingsisi, near Timor, East Indian Archipelago.

3. Archæolithothamium episporum. Howe. P'oint Toro, near Colon, Isthmus of Panama.

4. Lithophyllum cruspedium Foslie. Palmyra Island, in the Pacific Ocean, west of south from Ilawaii; latitude, $5^{\circ} 49^{\prime} \mathrm{N}$

5. Lithophyllum pallescens Foslie. Jay of La Paz, Gulf of California; latitude, $24^{\circ} 16^{\prime} \mathrm{N}$.

6. Lithophyllum dadaleum Foslie and Howe. Salinas Bay, near Guanica, P'orto Rico; latitude, about $18^{\circ} \mathrm{N}$.

7. Lithophyllum antillarum Foslie and Howe. Culebra Island, Porto Rico; latitude, about $15^{\circ} 20^{\prime} \mathrm{N}$.

S. Lithophyllum oncodes Ifeydrich. Coetiry Island, in the Indian Ocean, northeast of Madagascar; latitude, $7^{\circ}$ $6^{\prime} \mathrm{S}$; longitude, $56^{\circ} 30^{\prime} \mathrm{E}$.

9. Lithophyllum internedium Foslie. Fort Clarence, near Kingston, Jamaica.

10. Lithophyllum pachydermum Foslie. Dollar Harbor, South Cat Cay, Bahamas; latitude, about $25^{\circ} \mathrm{N}$. 
11. Lithophyllum tamiense Heydrich. New Guinea.

12. Amphiroa fragilissima Lamouroux. Lemon Bay, near Guanica, Porto Ricu.

13. Phymatolithon compactum Foslie. Torbay, Newfoundland.

14. Goniolithon acropetum Foslie and Howe. Culebra Island, Porto Rico.

15. Goniolithon strictum Foslie. Bemini Harbor, Bahamas.

16. Goniolithon strictum. Soldiers Key, Fla.

The actual analyses are as follows:

Analyses of algr.

\begin{tabular}{|c|c|c|c|c|c|c|c|c|}
\hline & 1 & 2 & 3 & 4 & 5 & (j) & 17 & 8 \\
\hline 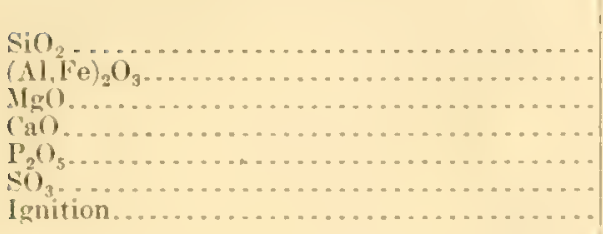 & \begin{tabular}{r|}
0.41 \\
.23 \\
4.78 \\
45.41 \\
Trace. \\
48.00
\end{tabular} & $\begin{array}{r}0.19 \\
.12 \\
7.52 \\
42.96 \\
\text { Trace. } \\
.61 \\
77.89\end{array}$ & $\begin{array}{r}1 . .17 \\
.89 \\
5.93 \\
41.80 \\
\text { Trace. } \\
.53 \\
45.69\end{array}$ & $\begin{array}{r}0.03 \\
.09 \\
8.64 \\
41.56 \\
.03 \\
.15 \\
48.37\end{array}$ & $\begin{array}{r}1.01 \\
.22 \\
6.42 \\
40.39 \\
.11 \\
.71 \\
49.94\end{array}$ & $\begin{array}{r}0.18 \\
.08 \\
8.14 \\
40.48 \\
\text { Trace. } \\
.44 \\
49.99\end{array}$ & $\begin{array}{r}0.01 \\
.10 \\
7.24 \\
43.31 \\
\text { Trace. } \\
.57 \\
48.11\end{array}$ & $\begin{array}{r}0.09 \\
.12 \\
8.07 \\
42.57 \\
.08 \\
.27 \\
47.96\end{array}$ \\
\hline $\begin{array}{l}{ } \mathrm{O}_{2} \text { needed. } \\
\text { Organic matter, etc } \ldots \ldots \ldots \ldots \ldots \ldots \ldots\end{array}$ & $\begin{array}{r}98.97 \\
40.86 \\
7.14\end{array}$ & $\begin{array}{r}99.29 \\
41.69 \\
6.20\end{array}$ & $\begin{array}{r}99.31 \\
41.43 \\
4.26\end{array}$ & $\begin{array}{r}98.87 \\
42.04 \\
6.33\end{array}$ & $\begin{array}{l}98.80 \\
38.31 \\
11.63\end{array}$ & $\begin{array}{r}99.31 \\
40.51 \\
9.48\end{array}$ & $\begin{array}{r}99.40 \\
41.70 \\
6.41\end{array}$ & $\begin{array}{r}99.16 i \\
42.11 \\
5.85\end{array}$ \\
\hline & 9 & 10 & 11 & 12 & 13 & 14 & 15 & 16 \\
\hline 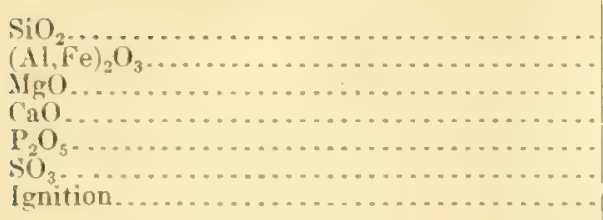 & $\begin{array}{r}0.27 \\
.21 \\
7.25 \\
42.55 \\
\text { Trace. } \\
.02 \\
48.63\end{array}$ & $\begin{array}{r}0.04 \\
.08 \\
6.47 \\
42.60 \\
.00 \\
.59 \\
49.55\end{array}$ & $\begin{array}{r}0.12 \\
.16 \\
8.81 \\
41.07 \\
\text { Trace. } \\
.69 \\
48.77\end{array}$ & \begin{tabular}{r|}
2.82 \\
1.31 \\
6.71 \\
34.82 \\
Trace. \\
.56 \\
48.78
\end{tabular} & $\begin{array}{r}0.10 \\
.23 \\
4.02 \\
38.19 \\
.10 \\
.52 \\
55.42\end{array}$ & $\begin{array}{r}0.06 \\
.04 \\
8.27 \\
40.60 \\
.18 \\
.62 \\
49.56\end{array}$ & $\begin{array}{r}0.02 \\
.01 \\
10.39 \\
38.51 \\
\text { Trace. } \\
.60 \\
49.91\end{array}$ & $\begin{array}{r}0.05 \\
10.93 \\
35.03 \\
\text { Trace. } \\
.61 \\
49.91\end{array}$ \\
\hline 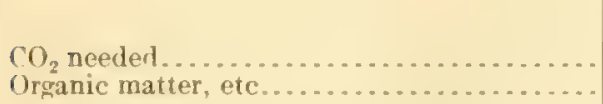 & $\begin{array}{r}98.93 \\
41.89 \\
6.74\end{array}$ & $\begin{array}{r}99.33 \\
40.24 \\
9.31\end{array}$ & $\begin{array}{r}99.62 \\
41.58 \\
7.19\end{array}$ & $\begin{array}{l}95.00 \\
34.43 \\
14.35\end{array}$ & $\begin{array}{l}98.58 \\
35.05 \\
20.37\end{array}$ & $\begin{array}{r}99.33 \\
10.50 \\
9.06\end{array}$ & $\begin{array}{r}99.47 \\
41.38 \\
8.53\end{array}$ & $\begin{array}{r}99.53 \\
41.56 \\
8.35\end{array}$ \\
\hline
\end{tabular}

The low summation of No. 12, a very fragile form, is due to inclosed salts, mainly alkaline chlorides and sulphates. These were determined as 5.40 per cent, which brings the summation up to 100.40 .

Reducing the analyses, as usual, to standard form, we have the following table:

Reduced analyses of algx.

\begin{tabular}{|c|c|c|c|c|c|c|c|c|}
\hline & 1 & 2 & 3 & 4 & 5 & 6 & 7 & s \\
\hline \multirow[t]{3}{*}{ 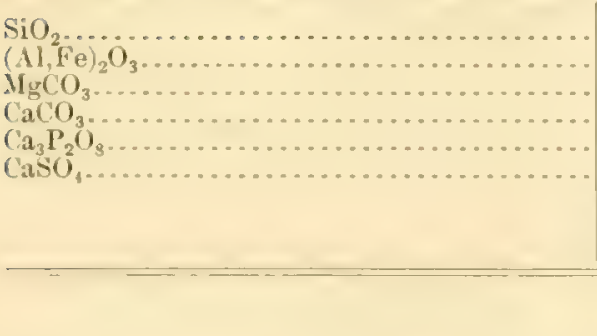 } & $\begin{array}{r}0.15 \\
.25 \\
10.93 \\
88.11 \\
\text { Trace. } \\
.26\end{array}$ & $\begin{array}{r}0.20 \\
.13 \\
16.96 \\
81.59 \\
\text { Trace. } \\
1.12\end{array}$ & $\begin{array}{r}1.55 \\
.94 \\
13.04 \\
83.47 \\
\text { Trace. } \\
.95\end{array}$ & $\begin{array}{r}0.03 \\
.10 \\
19.60 \\
79.92 \\
.05 \\
.27\end{array}$ & $\begin{array}{r}1.16 \\
.25 \\
15.46 \\
81.49 \\
.26 \\
1.39\end{array}$ & $\begin{array}{r}0.20 \\
.09 \\
19.03 \\
79.85 \\
\text { Trace. } \\
.83\end{array}$ & $\begin{array}{r}0.04 \\
.11 \\
16.35 \\
82.46 \\
\text { Trace. } \\
1.04\end{array}$ & $\begin{array}{r}0.10 \\
.13 \\
18.17 \\
80.93 \\
.18 \\
.49\end{array}$ \\
\hline & 100.00 & 100.00 & 100.00 & 100.00 & 100.00 & 100.00 & 100.00 & 100.00 \\
\hline & 9 & 10 & 11 & 12 & 13 & 14 & 15 & 16 \\
\hline \multirow[t]{2}{*}{ 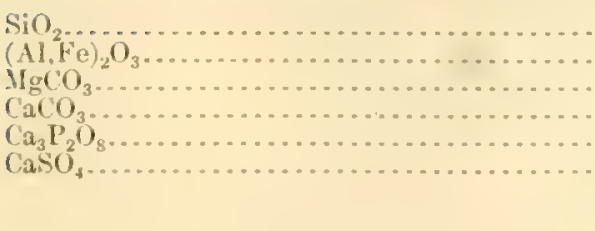 } & $\begin{array}{r}0.30 \\
.23 \\
16.59 \\
82.85 \\
\text { Trace. } \\
.03\end{array}$ & $\begin{array}{r}0.04 \\
.09 \\
15.08 \\
83.68 \\
\text { Trace. } \\
1.11\end{array}$ & $\begin{array}{r}0.13 \\
.17 \\
20.02 \\
78.13 \\
\text { Trace. } \\
1.25\end{array}$ & $\begin{array}{r}3.50 \\
1.62 \\
17.47 \\
76.23 \\
\text { Trace. } \\
1.18\end{array}$ & $\begin{array}{r}0.13 \\
.30 \\
10.93 \\
87.21 \\
.29 \\
1.14\end{array}$ & $\begin{array}{r}0.07 \\
.05 \\
19.24 \\
79.05 \\
.43 \\
1.16\end{array}$ & $\begin{array}{r}0.02 \\
.01 \\
24.00 \\
7.1 .83 \\
\text { Trace. } \\
1.12\end{array}$ & $\begin{array}{r}0.06 \\
25.17 \\
73.63 \\
\text { Trace. } \\
1.14\end{array}$ \\
\hline & 100.00 & 100.00 & 100.00 & 100.00 & 100.00 & 100.00 & 100.00 & 100.00 \\
\hline
\end{tabular}


In No. 12, Amphiroa, the high silica and sesquioxides are eridently impurities. If they are rejected, the percentage of magnesium carbonate rises to 18.41.

Of Halimeda, four species were analyzed, as follows:

17. Ifalimeda opuntia Lamouroux. Key West, Fla.

18. Halimeda simulans Howe. East of Guanica Harbor, Porto Rico.

19. Ifalimeda tridens Lamouroux. Cayo Maria Langa, Bay of Guayanilla, Porto Rico.

20. Halimeda monile Lamouroux. Same locality as No. 19.

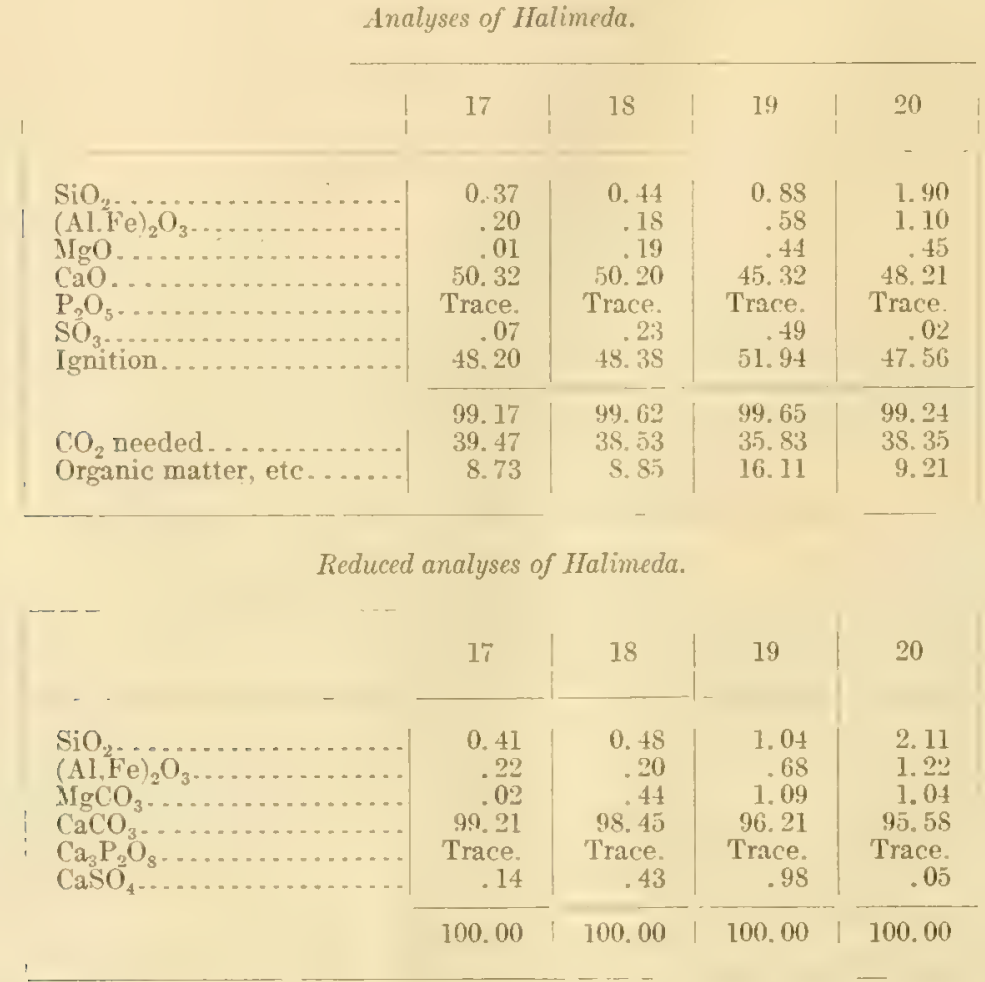

After allowance is made for obvious impurities the essential identity of these four analyses becomes clear. The inorganic portion of Halimeda consists of calcium carbonate and an insignificant amount of magnesia. In the first group of algæ, Nos. 1 to 16 , magnesium carbonate is conspicuous, more so than in any other class of organisms so far analyzed. In Goniolithon strictum especially it ranges from 24 to over 25 per cent, or more than halfway to dolomite. These algæ are probably the largest contributors of magnesia to the marine limestones.

It is also noteworthy that the two algx of the first group, Nos. 1 and 13, are from the cold waters of Newfoundland, and that the others are from tropical or subtropical regions. Several, if not all of them, are shoal-water organisms and were collected on reefs, or rocks, or on sands near low-tide levels. It is desirable that Arctic species should be carefully studied-at least more carefully than hitherto. The older published data leare much to be desired, especially as to definiteness of species and localities.

In addition to the material received from Dr. Howe, three more calcareous algæ were submitted for analysis by T. Wayland Vaughan. The species, with analyses by A. A. Chambers, are as follows:

1. Goniolithon fratescens Foslie. Cocos-Keeling Islands, in the Indian Ocean; latitude, $12.5^{\circ} \mathrm{S}$; Iongitude, $96.53^{\circ} \mathrm{F}$

2. Goniolithon orthoblastum (Heydrich) Howe. Murray Island, Torres Straits, Australia.

3. Lithophyllum kaiseri Heydrich. Cocos-Keeling Islands. 
Inalyses of alya.

\begin{tabular}{|c|c|c|c|}
\hline & 1 & 2 & 3 \\
\hline 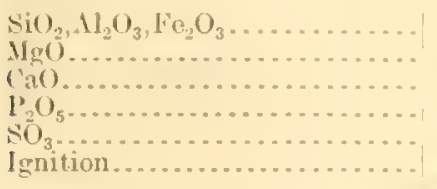 & $\begin{array}{r}0.07 \\
\text { 6. } 29 \\
4 \text { fi. } 16 \\
\text { I'race. } \\
.00 \\
46.70\end{array}$ & $\begin{array}{r}0.11 \\
5.71 \\
42.39 \\
\text { Trace. } \\
.00 \\
50.97\end{array}$ & $\begin{array}{r}0.28 \\
7.09 \\
45.92 \\
\text { Trace. } \\
.00 \\
45.72\end{array}$ \\
\hline 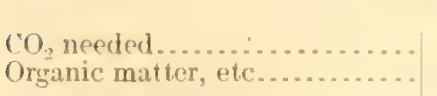 & $\begin{array}{r}99.22 \\
43.19 \\
3.51\end{array}$ & $\begin{array}{l}99.18 \\
39.59 \\
11.38\end{array}$ & $\begin{array}{r}99.01 \\
43.88 \\
1.81\end{array}$ \\
\hline \multicolumn{4}{|c|}{ 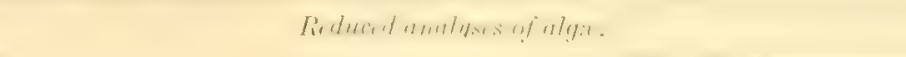 } \\
\hline & 1 & 2 & 3 \\
\hline 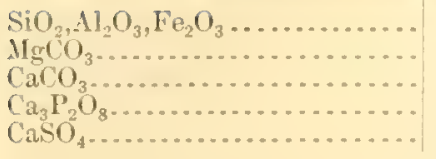 & $\begin{array}{r}0.07 \\
13.80 \\
\text { S6. } 13 \\
\text { Trace. } \\
.00\end{array}$ & $\begin{array}{r}0.12 \\
13.66 \\
86.22 \\
\text { Trace. } \\
.00\end{array}$ & $\begin{array}{r}0.29 \\
15.33 \\
\text { S4. } 38 \\
\text { Trace. } \\
.00\end{array}$ \\
\hline & 100.00 & 100.00 & 100.00 \\
\hline
\end{tabular}

These alga are much lower in magnesia than our specimens from similarly warm regions. The two species of Goniolithon contain little more than half as much magnesium carbonate as the species from Florida and the West Indies. That this difference might be due to differences of age or maturity seemed to be possible, and therefore two more alga were obtained from Dr. Howe and analyzed by R. M. Kamm with the following results:

1. Lithophyllum pachydermum, Dollar Harbor, South Cat Bay, Bahamas.

1a. Lipper or younger layer, solid.

1b. Lower or older layer, porous and somewhat discolored.

2. Goniolithon strictum, Bemini Harbor, Bahamas.

2a. Upper or younger branches.

2h. Lower or older branclies.

Actual analyses of algx.

\begin{tabular}{|c|c|c|c|c|}
\hline & $1 \Omega$ & Ib & $2 \mathrm{a}$ & $2 b$ \\
\hline 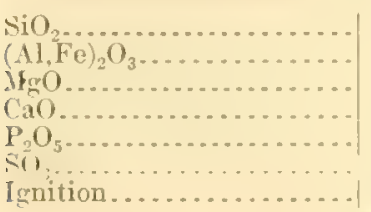 & $\begin{array}{r}0.04 \\
.11 \\
10.69 \\
37.66 \\
\text { Trace. } \\
-.9 \\
50.64\end{array}$ & $\begin{array}{r}0.09 \\
.14 \\
6.5 \frac{1}{2} \\
44.85 \\
\text { Trace. } \\
.71 \\
17.51\end{array}$ & $\begin{array}{r}0.02 \\
.32 \\
9.64 \\
37.64 \\
.00 \\
.6 .2 \\
51.14\end{array}$ & $\begin{array}{r}0.08 \\
.57 \\
10.26 \\
38.25 \\
.00 \\
.65 \\
45.76\end{array}$ \\
\hline 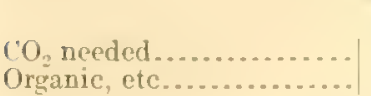 & $\begin{array}{r}99.93 \\
41.42 \\
8.73\end{array}$ & $\begin{array}{r}09.87 \\
42.08 \\
5.43\end{array}$ & $\begin{array}{l}99.39 \\
39.83 \\
11.31\end{array}$ & $\begin{array}{r}95.59 \\
40.97 \\
7.79\end{array}$ \\
\hline
\end{tabular}

Rcduccd analyscs of alga'.

\begin{tabular}{|c|c|c|c|c|}
\hline \multirow{3}{*}{ 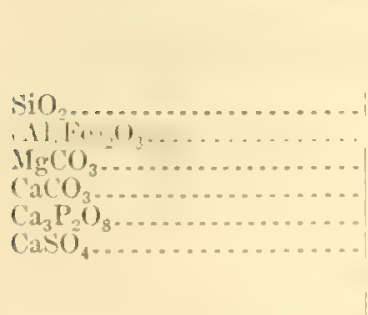 } & $1 \mathrm{a}$ & $1 \mathrm{~b}$ & $2 a$ & $2 \mathrm{~b}$ \\
\hline & $\begin{array}{r}0.04 \\
1.2 \\
24.95 \\
73.65 \\
\text { Trace. } \\
\text { 1. } 24\end{array}$ & $\begin{array}{r}0.09 \\
1.1 \\
15.43 \\
83.06 \\
\text { 'Trice. } \\
1.27\end{array}$ & $\begin{array}{r}0.02 \\
2.31 \\
22.98 \\
75.42 \\
.00 \\
1.22\end{array}$ & $\begin{array}{r}0.09 \\
.1 . .7 \\
23.74 \\
74.39 \\
.00 \\
1.25\end{array}$ \\
\hline & 100.00 & 100.00 & 100.00 & 100.00 \\
\hline
\end{tabular}


From these analyses no positive conclusions can be drawn. In No. 1 the older layer is much impoverished in magnesium carbonate, and its porous character indicates an alteration by leaching. In No. 2 the difference is very slight, but the older branches are a little richer in magnesia than the younger ones. 'That differences of composition may exist in different parts of the same specimen is, however, manifested.

To Prof. L. R. Cary, of Princeton University, we are indebted for two unpublished analyses of calcareous alga by Prof. A. H. Phillips. In one, from Samoa, he found 36.36 per cent of magnesium carbonate, an astonishingly high figure. In the other, from southern Florida or the Tortugas he found, in percentages, $\mathrm{CaCO}_{3}, 73.23 ; \mathrm{MgCO}_{3}, 25.32$; and $\mathrm{Ca}_{3} \mathrm{P}_{2} \mathrm{O}_{8}, 0.35$; total, 98.90. This analysis agrees well with ours of Goniotithon from the same region.

Of the earlier analyses of calcareous alga those by $\Lambda$. Damour ${ }^{45}$ are the most complete and most nearly comparable with ours. Five species were analyzed, as follows:

1. Lithophyllum sp. Mediterranean Sea.

2. Melobesia sp. Coast of Algeria.

3. Amphiroa tribulus. Antilles.

4. Halimeda opuntia. Red Sea,

5. Galaxaura fragilis. Antilles.

Damour's "Millepora cervicornis," of which he gives an analysis, is not included here on account of its doubtful character. (See p. 15.)

Damour's analyses of algæ.

\begin{tabular}{|c|c|c|c|c|c|}
\hline & & & & & \\
\hline & 1 & 2 & 3 & 4 & 5 \\
\hline $\mathrm{CaCO}_{3} \ldots$ & 77.36 & 72.78 & 70.83 & 86.17 & 72.56 \\
\hline $\mathrm{MgCO}_{3} \ldots$ & 11. 32 & 12.32 & 16.99 & .56 & .86 \\
\hline $\mathrm{Na}_{2} \mathrm{O} \ldots \ldots . . .$. & .55 & 1.75 & .89 & 1.13 & .73 \\
\hline $\mathrm{K}_{2} \Theta \ldots$ & .27 & .65 & .39 & .54 & 1.02 \\
\hline$F()_{3}, \ldots$ & .08 & .20 & & & \\
\hline $\mathrm{SO} 0_{3} \ldots \ldots \ldots$ & .95 & 1.25 & .93 & (?) & (? \\
\hline 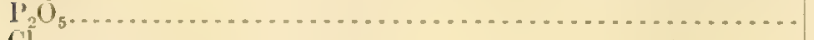 & .32 & .38 & .27 & (?) & $(?)$ \\
\hline 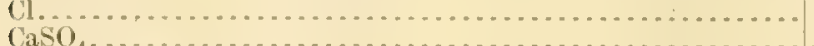 & .60 & .34 & .53 & .84 & 1.17 \\
\hline 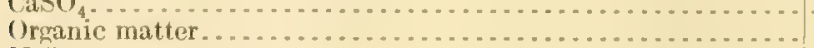 & 4.70 & 3.95 & 6. 40 & 8.30 & $\begin{array}{r}1.80 \\
17.50\end{array}$ \\
\hline 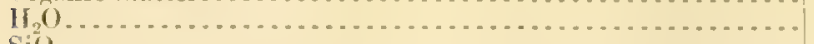 & 1. 46 & 1.40 & 1.38 & .90 & .95 \\
\hline \multirow{3}{*}{ 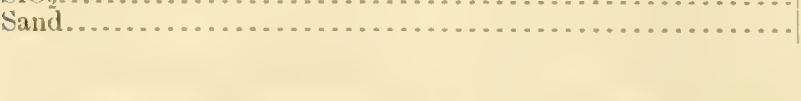 } & 1.36 & 428 & & & 2.20 \\
\hline & & & & & 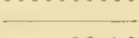 \\
\hline & 98.97 & 99.30 & 98.81 & 98.99 & 98.79 \\
\hline
\end{tabular}

In these analyses $\mathrm{Na}_{2} \mathrm{O}, \mathrm{K}_{2} \mathrm{O}, \mathrm{Cl}$, and $\mathrm{SO}_{3}$ evidently represent sea salts. Rejecting them as impurities, together with the organic matter, water, and sand, and recalculating to 100 per cent, we have the following reduced analyses, which are similar to ours:

Damour's analyses reduced.

\begin{tabular}{|c|c|c|c|c|c|}
\hline & 1 & 2 & 3 & 4 & 5 \\
\hline \multirow[t]{2}{*}{ 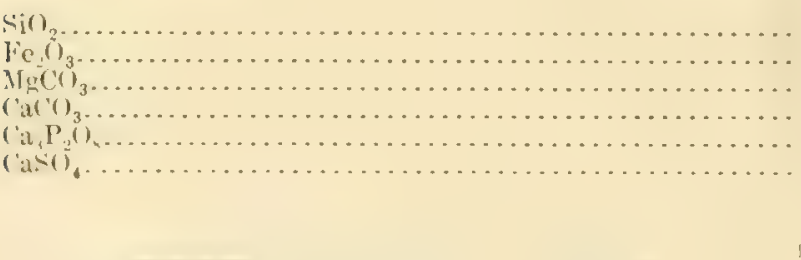 } & $\begin{array}{r}0.09 \\
12.76 \\
86.36 \\
.79 \\
\end{array}$ & $\begin{array}{r}0.23 \\
14.44 \\
81.36 \\
.97 \\
\ldots \ldots\end{array}$ & $\begin{array}{r}19.29 \\
79.81 \\
.67 \\
.23\end{array}$ & $\begin{array}{c}0.64 \\
98.73 \\
(?) \\
.63\end{array}$ & $\begin{array}{l}2.81 \\
1.11 \\
93.73 \\
2.32\end{array}$ \\
\hline & 100.00 & 100.00 & 100.00 & 100.00 & 100.00 \\
\hline
\end{tabular}

\footnotetext{
4s Damour, A., Compt. Rend., vol. 32, p. 253, 1851.
} 
Three of these alga are highly magnesian; Hatimede and Galaxaura are not.

Two analyses of alga by $\Lambda$. Schwager were published by J. Walther ${ }^{46}$ in 1855. There is also one by C. WT. Gümbel, ${ }^{77}$ and these three may be combined in one table, as follows:

1. Lithothamnium sp. Bay of Naples; 1 . Schwager, analyst.

2. Lithothamnium ramulosum. Bay of Naples; 1. Schwager, analyst.

3. Isthothamnium nodosum. Locality not stated; ( '. W. Gümbel, analyst. Actual analyses of algx.

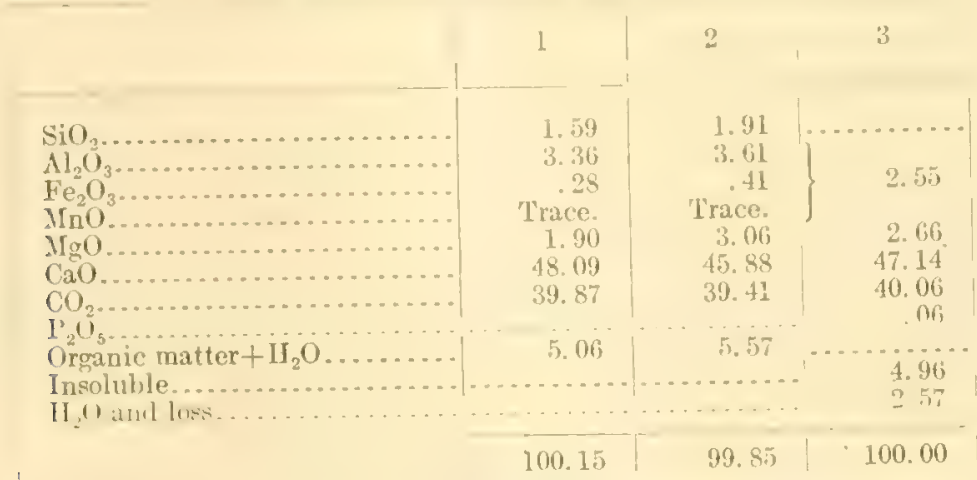

Reducing these to uniformity with our analyses we have the following table: Reduced analyses of algx.

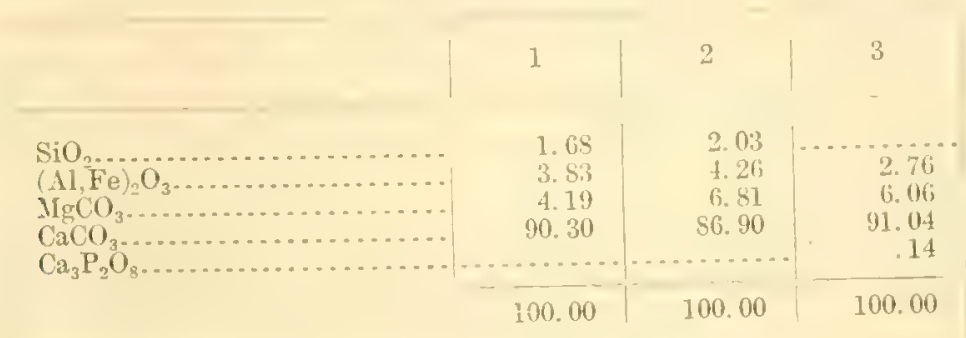

In these analyses, all of Lithothamnium, the percentage of magnesium carbonate is remarkably low. Why this should be so is not clear, hut it may he due to differenees in the age of the plants: that is, young specimons may have serereded less mangesiat proportionally to lime than older, more mature eximples. This sugerention might well be tested by special analyeses of properly selected material. Intil that has heen done the surerestion can carry little weight.

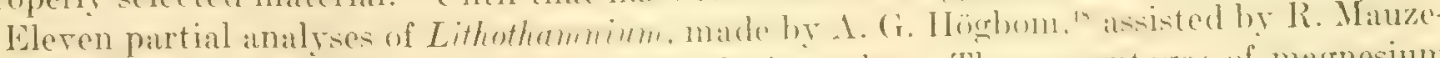
lius, N. Sahlbom, and J. Guinchard, are curiously irregulatr. The perentanes of magnesium carbonate vary enormously, and with no apparent or even probable relation to temperatures. The data given are as follows:

\begin{tabular}{|c|c|c|}
\hline & $\mathrm{CaCO}_{3}$ & $\mathrm{MgCO}{ }_{3}$. \\
\hline 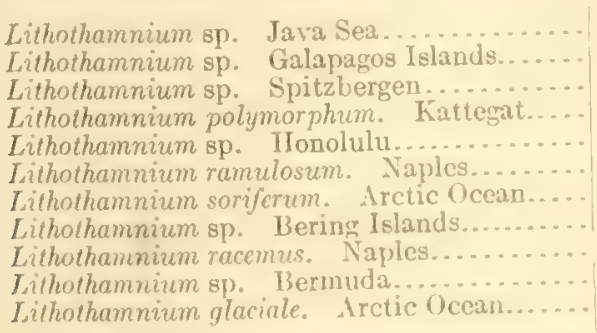 & $\begin{array}{l}72.03 \\
53.60 \\
84.83 \\
7.1 .22 \\
84.01 \\
63.00 \\
50.90 \\
74.24 \\
77.39 \\
82.14 \\
\text { S3.10 }\end{array}$ & $\begin{array}{l}3.76 \\
6.53 \\
8.67 \\
9.10 \\
9.39 \\
9.16 \\
9.56 \\
9.94 \\
11.33 \\
12.37 \\
13.19\end{array}$ \\
\hline
\end{tabular}

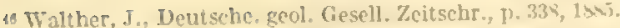

" Gümbel, C. W. K. bayer. Akad. Wiss. Abh., Math.-phys. Classe, vol. 11, 1. 200, 15i1.

\&s Högbom, A. G., Neues Jahrb., 159t, Band 1, p. 2tiz 
In this series the percentages of magnesium carbonate are much lower than those found by us, and there is uncertainty in six examples as to the exact species. Högbom, however, points out the importance of these alga in respect to the formation of dolomite, which was the real subject of his investigation. In Halimeda sp., from Labuan, only a trace of magnesia was found.

In Lithothamnium racemus, from the Bahamas, H. W. Nichols ${ }^{49}$ found 5.35 per cent of magnesium carbonate, but without rejection of organic matter, etc., undetermined. This percentage is remarkably low. A similar low figure for magnesium carbonate -5.85 per centwas found by E. W. Skeats ${ }^{50}$ in Lithothamnium phillipi var. funafutiensis Foslie. The specimen was taken on the atoll of Funafuti.

In a very fresh Halimeda opuntia Skeats found 0.60 per cent of $\mathrm{MgCO}_{3}$ and 86.50 of $\mathrm{CaCO}_{3}$, but in a mass of fronds dredged up from a depth between 50 and 60 fathoms the percentages were $4.0 \mathrm{MgCO}_{3}$ to $93.59 \mathrm{CaCO}_{3}$. The increase in magnesia may have been due to concentration by leaching. These data are given by J. W. Judd, ${ }^{51}$ who also cites an analysis of dead Halimeda fronds made for him by C. G. Cullis, who found in them 1.39 per cent of $\mathrm{MgCO}_{3}$ and 98.32 of $\mathrm{CaCO}_{3}$. Judd also quotes an analysis of Halimeda, cited by Payen in his Flora, which contrined 5.50 per cent of $\mathrm{MgCO}_{3}$ and 90.16 of $\mathrm{CaCO}_{3}$. The character of the specimen represented by the last analysis, whether fresh or old, is uncertain. The best analyses agree in assigning little magnesium to Halimeda.

In an important memoir on Melobesia Madame P. Lemoine ${ }^{53}$ gives several analyses of calcareous algx. 'The analyses, made for her by M. Charf, are not very complete, but they are, nevertheless, of distinct value. The data are as follows:

1. Lithothamnium calcareum. St.-Vaast-la-Hougue, Manche, France.

2. Lithothamnium calcareum. Isle Glenan, Finistere, France.

3. Lithothamnium fornicatum. Norway.

4. Lithophyllum incrustans. Gatteville, Manche, France.

5. Lithophyllum incrustans. Mazagan, Morocco.

6. Lithophyllum tortuosum. Genoa.

7. Lithophyllum craspedium. Tahiti.

'To the analyses as reproduced in the following table we venture to add a line for reduced or corrected magnesium carbonate, computed on the basis of 100 per cent for the two carbonates alone.

Lemoinc's analyses of algà.

\begin{tabular}{|c|c|c|c|c|c|c|c|}
\hline & 1 & 2 & 3 & 4 & 5 & 6 & 7 \\
\hline 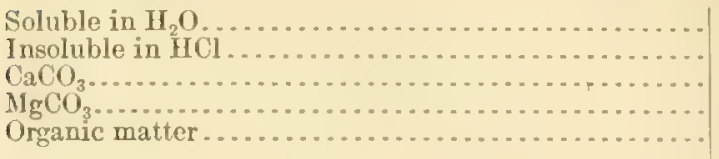 & $\begin{array}{r}2.3 \\
80.9 \\
11.8 \\
5.0\end{array}$ & $\begin{array}{r}\text { 3. } 0 \\
.0 \\
75.2 \\
10.7 \\
11.1\end{array}$ & $\begin{array}{r}1.2 \\
81.0 \\
9.3 \\
7.9\end{array}$ & $\begin{array}{r}1.7 \\
.0 \\
84.4 \\
10.8 \\
3.1\end{array}$ & $\begin{array}{r}3.8 \\
.0 \\
77.7 \\
9.8 \\
8.7\end{array}$ & $\begin{array}{r}5.7 \\
6.2 \\
73.4 \\
9.3 \\
5.4\end{array}$ & $\begin{array}{r}3.2 \\
75.0 \\
15.9 \\
5.5\end{array}$ \\
\hline $\mathrm{MgCO}_{3}$ corrected........ & $\begin{array}{r}100.0 \\
12.7\end{array}$ & $\begin{array}{r}100.0 \\
12.5\end{array}$ & $\begin{array}{r}100.0 \\
10.2\end{array}$ & $\begin{array}{r}100.0 \\
11.3\end{array}$ & $\begin{array}{r}100.0 \\
11.2\end{array}$ & $\begin{array}{r}100.0 \\
11.2\end{array}$ & $\begin{array}{r}100.0 \\
17.4\end{array}$ \\
\hline
\end{tabular}

In this series the highest magnesia is in the alga from 'Tahiti and the lowest in that from Norway. This tendency toward increased magnesia in alga from warm regions, as compared with those from cold waters, was noticed by Madame Lemoine but only incidentally. The subject was not given any detailed consideration by her.

Madame Lemoine also cites the older analyses of alga, including three by J. Chalon, as follows:

1. Lithothamnium calcareum. Roscoff, Finistere, France.

2. Lithophyllum incrustans. Banyuls, France, on the Mediterranean.

3. Lithophyllum tortuosum. Naples.

19 Nichols, H. W. Field Columbian Mus. Pub. 111, p. 31, 1906

so Skeats, E. W., The atoll of Funafuti, pp. 376, 377, London, The Royal Society, 1901.

si Judd, J. W., idem.

'Lemoine, P., Inst. océanographique Monaco Annales, vol. 2, fasc. 2, 1911. 
Chalon's analyses of algx.

\begin{tabular}{|c|c|c|c|}
\hline 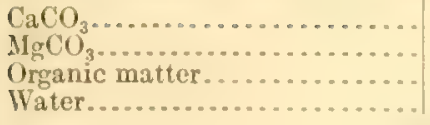 & $\begin{array}{r}82.41 \\
11.80 \\
4.30 \\
.86\end{array}$ & $\begin{array}{r}76.06 \\
14.38 \\
7.38 \\
1.72\end{array}$ & $\begin{array}{r}82.20 \\
11.57 \\
5.26 \\
.80\end{array}$ \\
\hline $\mathrm{MgCO}_{3}$ corrected................. & $\begin{array}{l}99.37 \\
12.52\end{array}$ & $\begin{array}{l}99.54 \\
15.90\end{array}$ & $\begin{array}{l}99.83 \\
12.35\end{array}$ \\
\hline
\end{tabular}

'These recent analyses, from the memoir of Madmone Lemoine, agree well with ours and, notwithstanding Högbom's dirergent data, strengthen the suggestion that the proportion of magnesia in the alga is influenced by temperature.

The material studied by us was carefully chosen by Dr. Howe, with direct reference to the purpose of our investigation. Every species was thoroughly identified, its locality was definitely stated, and the specimens were remarkably clean and free from misleading impurities. The results obtained by us are therefore as nearly trustworthy as it is practicable for us to make them. The significance of the alga in reference to dolomite was already well established by previous workers, but our new data strengthen the conclusions which our predecessors had drawn. ${ }^{53}$

\section{GENERAL DISCUSAION.}

In the foregoing pages we have reported 322 new analyses of marine invertebrates and have cited many other analyses made elsewhere. 'These data shed much light upon the chemistry of the marine sediments, and they also suggest various problems, some of them biological, which are yet to be solved. The limitations of our research have been pointed out in the introduction to this memoir and are taken for granted in the following general discussion of the results that we have obtained. First in order we may consider the distribution of the essential constituents of the invertebrate skeletons, taking each one separately.

Sitica.-The skeletons of radiolarians and diatoms and the spicules of siliceous sponges consist almost entirely of opaline silica. The radiolarian and diatom oozes of the Challenger expedition show the importance of these organisms. In our own work we have studied only the sponges, and our results show nothing new. Our analysis of Euplectella, howerer, is probably more complete than any previous analysis of a siliceous sponge. We have found recorded in the literature only partial analyses of sponge spicules.

In nearly all our analyses, in every group of organisms, silica appears, generally in small but exceptionally in rather large proportions. Some of this may be essential, but in most cases it is an impurity. In fact, sand grains were distinctly visible in some of the specimens analyzed, but were not readily removable.

Alumina and iron oxide.-In most of our analyses alumina and iron oxide woro usually determined, but they are to be regarded generally as impurities due to adherent silt or mud. Iron is doubtless a normal constituent in small amounts.

Lime.-The most important base in nearly all marine shells or skeletons, whether vertebrate or invertebrate, is lime. Only the siliceous organisms are free from it. Molluscan shells, the stony corals, the hard parts of millepores, some brachiopods, and the barnacles are composed almost entirely of calcium carbonate and contain only minor impurities. In the other series of marine invertebrates, with few exceptions, it is the dominant inorganic constituent. Calcium phosphate and sulphate wero also determined in most of our analyses, but they will be considered in other paragraphs.

Magnesia.-One of the most interesting results of our investigation is the discovery that magnesium carbonate is much more widely distributed as an assential constituent of marine invertebrates than it has hitherto been supposed to be. In the Foraminifera, alcyonarians, echinoderms, crustaceans, and coralline alga it is especially important, and some other organisms contain it in notable proportions. Its peculiar relations to temperature have been noted in several sections of this work and will be discussed more fully later.

i3 On the importance of alga as reef builders, see an interesting paper by Dr. Howe in Science, new ser., $\nabla 01.35, \mathbf{p} .837,1912$. He cites much other literature. 
Our determinations of magnesia, however, are subject to at least one small correction. Many of the specimens analyzed contained inclosed or adherent sea salts, and in a few of them they could not be estimated. They rarely amounted to more than 2 per cent, but in one analysis 5 per cent was found. Sea salts contain magnesium, and its equiralent in magnesium carbonate must therefore be deducted from the percentages of magnesium carbonate giren in our reduced analyses. The maximum correction to be thus applied is about 0.4 per cent, but 0.1 per cent would be the more common amount. In our work such a correction is negligible, for the proportion of magnesium carbonate in our important magnesian series ranges from 5 to 25 per cent. The small quantities of magnesia found in most mollusks and corals, however, may be due in part, if not entirely, to saline impurities.

Phosphorus.- In nearly all our analyses phosphoric oxide appears, but generally in trifling quantities. It is abundant, however, in the series of phosphatic brachiopods, the crustaceans, and the alcyonarians. Some worm tubes also are notably phosphatic. In reducing the analyses to standard form we have assumed that the phosphoric oxide is best represented in combination as tricalcium phosphate, although the assumption is not absolutely proved. It is a pure convention, adopted for the sake of uniformity and to simplify the comparison of analyses. It is of course possible that magnesium phosphates may exist in some of the organisms and that a part of the phosphorus may be contained in their organic matter. Magnesium phosphates, however, are very rare as minerals, whereas calcium phosphate is extremely common. 'The organic matter decomposes after the death of the animals, and its phosphorus would doubtless appear in the sediments as a phosphate. In any case the dead organisms are likely to be buried among calcareous sediments, where calcium phosphate should be formed. Even the phosphatic worm tubes, in which the calcium is insufficient to form a tribasic salt, would probably follow this rule. Lime from the sediments would supply the deficiency.

Sulphur.-In many of our analyses sulphur was determined as sulphur trioxide and recalculated into the form of calcium sulphate. Part of the sulphur may really exist in organic combination, especially in the phosphatic brachiopods, and another part may be derived from sea salts, but this part is extraneous and should not be considered as contributory to the sediments. A correction for it would be like that which we have regarded as applicable to the magnesia and of the same order of magnitude. In the marine sediments generally calcium sulphate is of minor importance.

Other constituents.-Among the inorganic constituents of invertebrates there are other elements than those which we have determined. The most important one of these is fluorine, which is probably present in small amount in all living organisms. P. Carles, ${ }^{54}$ for examplo, has detected fluorine in the shells of mollusks-as much as 0.012 per cent in oyster shells. In combination with calcium phosphate fluorine may form a compound analogous to or identical with apatite. Its presence in rertebrate bones is well known. Boron also is widely distributed in the animal kingdom. G. Bertrand and H. Agulhon ${ }^{55}$ detected it in crustaceans, mollusks, and echinoderms, as well as in vertebrate animals. Traces of barium hare been detected in various organisms, and in the soft part of certain rhizopods granules of barium sulphate have been found. ${ }^{58}$ Strontium is reported by O. Vogel ${ }^{57}$ in corals and molluscan shells, and according to $O$. Bütschli ${ }^{58}$ the skeleton of a radiolarian, Podecanelius, consists almost entirely of strontium sulphate. Iron and manganese are of common if not of general occurrence in marine organisms, and copper, lead, zinc, cobalt, and nickel have also been found. ${ }^{59}$ The presence of copper in oysters has long been known. Silver has been detected

54 Carles, P., Compt. Rend., vol. 1ł4, pp. $437,1240,1907$.

53 Bertrand, G., and Agulhon, H., idem, rol. 156, p. 732, 1913

${ }^{6}$ Cited by Samoilov in Mineralog. Mag., June, 1917.

Yogel, O., Zeitschr. anorg. Chem., vol. 5 , p. 55, 1891.

is Bütschli, O., Deutsche Südpolar Exped., vol. 9, p. 237, $190 \mathrm{~s}$

so See Forchhammer, G., Philos. Trans., vol. 15.5, p. 203, 1.865.

On manganese see Cotte, J., Soc. biologic Compt. rend., vol. 55, p. 139, 1903; Bradley, H. C., Jour. Biol. Chem., vol. 3, p. 151, 1907, and rol. \&, p. 237, 1910; Boycott, A. E., Naturalist, 1917, p. 69, and Phillips, A. II., Carnegie Inst. Washington Pub. 151, p. s9, 1917. Phillips also found iron, copper, and zine in the soft parts of invertebrates, and, rarely, lead. See also Mendel, L. B., and Bradley, H. C., Am. Jour. Physiology, rol. 14, p. 313, 1905. For copper, see Rose, W. C., and Bolansky, MI., Jour. Biol. Chem., vol. 44, p. 99, 1920. 
in oyster shells by $\boldsymbol{A}$. Liversidge, ${ }^{e n}$ and ranndium has been reported in tho blood of an ascidian by If. Henze, ${ }^{61}$ and in a holothurian by 1 . H. Phillips. ${ }^{62}$ In short, a systematic search for minor metallic constituents in marine invertebrates would probably show that they contain many other elements. This subject, howerer, lies outside the scope of our investigation, and these few citations are enough for present purposes.

For the intensive study of coral reefs the analyses furnished by us together with those cited from others are of great significance. The limestone immediately below the zone of liring forms owes its composition to all the organisms that flourished on the reef. Alga, corals,

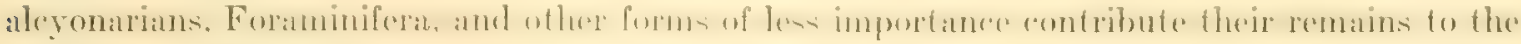
building of the limestone, which may vary in composition as the life upon it raries. Corals may predominate in one place, algx in mother. Each reef must therefore be studied on its individual merits if its chemical character is to be understood. Precipitated carbonates, whether of bacterial origin or not, must also be taken into account, and their quantity may be large. At Funafuti, where the limestone has been studied with unusual thoroughness, the order of importance of the leading organisms is estimated by $A$. E. Finckh ${ }^{83}$ as follows: 1, Lithothamnion; 2, Hatimeda; 3, Formminifera; 4, the corals, including Heliopora and other alcyonarians and the millepores. Here the corals are subordinate to the alga, and even the Foraminifera outrank them. To call the Funafuti rock a coralline limestone would therefore be somewhat misleading.

At other localities the relatice abundance of the marine organisms is different from that at Funafuti. A careful analysis of samples from reefs at Murray Island, Australia, conducted by T. Wayland Vaughan, ${ }^{65}$ gave the following results: "1,600 feet from shore, madreporarian corals, 41.9 per cent; calcareous alga, 32.6 per cent; Foraminifera, 12.4 per cent; Mfollusca, 10.2 per cent. At 200 feet from the shore the order is: Calcareous algæ, $\$ 2.5$ per cent; madreporarian corals, 34.6 per cent; Mollusca, 34.6 per cent; Forminifera, 4.1 per cent." Around the Tortugas, according to L. R. Cary, ${ }^{8 B}$ the alcyonarian fauna is the most important contributor to the formation of reef limestones. He estimates the cuantity of alcyonarian spicules at this locality to average 5.28 tons to the acre; and at least one-fifth of this amount is added to the reefs annually. In the Afurray Island samples studied by Vaughan the alcyonarian remains were lacking.

Chemical analysis, however, is not the only factor of importance in determining the composition of a marine limestone. The crystalline character of the shells and skeletons, whether calcitic or aragonitic, must also be considered. For this purpose the well-known reaction with cobalt nitrate, the "Meigen reaction," is commonly employed, especially by W. Meigen himself, who has studied a considerable number of organisms, both recent and fossil, and some of his determinations ${ }^{67}$ relate to generia examined by us. For these, excluding fossil forms, the data are as follows:

Calcite.
Lithothamnium. Mlga.
Lithoplıyllum. Mlga.
Polytrema. Foraminifer.
Corallium. Alcyonarian.
Tubipora. Alcyonarian.
Sernula. Annelid.
Terebratula. Brachiopod.
Argonauta. Cephalopod.
Balanus. Crustacean.

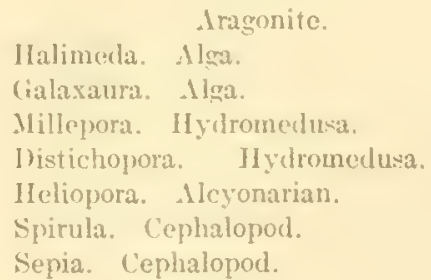

60 Liversidge, A., Jour. Chem. Soc., rol. il, p. 298, 1897

at Henze, M., Zeitschr. physiol. Chem., vol, 72, p. 401, 1911, and vol. 56, p. 340, 1913. Henze also found copper in the liver of cephalopods (idem, rol. $33, \mathrm{p} .417,1901$.

62 Phillips, A. II., Am. Jour. Sci., 4th ser., vol. 46, p. 473, 191

6a The atoll of Funafuti, pp. 12j-150, London, The Royal Society, 1904.

"4 The term Lithothamnion as used in the Funafuti report is gencral and includes not only Lithothnmium but also Lithophyllum, Goniolithon, and perhaps other genera. Sce The atoll of Funafuti, p. 332, London, The lroyal socivety, 1944.

65 Vaughan, T. IV., Geol. Sue. America 13ull., vol. 2s, p. 912, 1917.

66 Cary, L. R., Carnegie Inst. Washington l'ub. 213, 1914, 1). 356.

o7 Mcigen, W., Naturf. (iesell. F'reiburg 13er., vol. 13, p. 13, 1903. 
Of these genera, so far as they have been studied chemically, all in the aragonite column are almost completely nonmagnesian. The trifling amounts of magnesia which they contain may be due to impurity or to alteration. Two in the calcite column, Terebratula and Balanus, are also nonmagnesian, and the others are all rich in magnesium carbonate. Meigen also tested twenty zoantharian corals, all aragonitic and nonmagnesian, and a considerable number of mollusks. Some of the molluscan shells were aragonitic and some were calcitic, but all except Argonauta were nearly free from magnesia. One echinoderm in Meigen's list, of a genus not represented in our series of analyses, was calcitic, and so too were ours. All the echinoderms, so far as we know, are distinctly magnesian. In short, it seems probable, in the light of existing evidence, that all aragonitic organisms are essentially nonmagnesian; and that those characterized by the presence of much magnesia are calcitic. Many calcitic forms, however, are practically free from magnesia. The general relation thus brought out is very suggestive. Magnesium carbonate associates itself only with calcite, with which it is isomorphous, rather than with aragonite, of different crystalline form, but why some organisms should secrete calcite and others aragonite in building their shells or skeletons is as yet unexplained, although the difference may be of physiologic origin, and may perhaps be correlated with differences of structure.

The considerations presented in the preceding pages bear directly upon the problem of the origin of marine dolomite. We now know what classes of organisms supply magnesia to the limestones and something also of what may be called their mineralogic nature. The dolomite ratio between the two carbonates is, however, never directly reached; there is always at first a large excess of calcium over magnesium, and a mixture is formed instead of the true double salt. To produce dolomite the original limestone must either be enriched by magnesia derived from sea water or else concentrated by leaching away of lime; furthermore, its two component carbonates must be somehow forced to combine. These processes may be operative simultaneously, but it is more probable that the change from magnesian limestone or dolomite is brought about by a series of steps, taken one at a time.

In this connection the report on Funafuti, already cited, is remarkably suggestive. On that atoll or island a committee of the Royal Society put down a boring 1,114 feet, in limestone all the way. The rock throughout contained organic remains and was studied both microscopically and chemically. Lt a depth of 4 feet from the surface it contained 4.23 per cent of magnesium carbonate, and at 15 feet 16.4 per cent. To this point a concentration by leaching is indicated, eren if not absolutely proved, and it is probable that the relatively soluble nonmagnesian aragonitic structures had been in part at least dissolved away. The unstable aragonite is more easily dissolved than calcite, a relation so well established that it does not need to be discussed here. ${ }^{68}$ The fact that many sections of the core are described as "cavernous" in structure is additional evidence that solution had occurred. Solution is also aided by the carbonie acid generated during the decomposition of the organic matter of the organisms, and through its agency calcite would be dissolved also. Magnesium carbonate is much less readily removed.

At a depth of 25 feet the core contained 16 per cent of magnesium carbonate, but the specimen examined consisted largely of Lithothamnion remains, which accounts for its composition. On the other hand, the core at 40 feet carried only 5.85 per cent of magnesium carbonate and was in great part composed of Heliopora and Millepora, both originally nonmagnesian. The core sections evidently varied in composition according to the variations in the organisms from which they were formed. A sample taken only a few feet away from the boring might have had a different composition. Some fluctuations in the series of analyses may be accounted for in this way.

Below 40 feet the magnesian content of the rock diminished rapidly, falling at one point to 0.79 per cent of magnesium carbonate. Between 40 and 637 feet the composition of the rock was about that of an ordinary limestone, but at the latter depth crystals of dolomite

This leaching at Funafuti has alrealy been pointed out by J. W. Judd in The atoll of Funafuti, p. 384. 
began to appear. ${ }^{60}$ At 640 feet the percentage of magnesium carbonate was 26.33 , and it increased, with some fluctuations, to the final depth of $1,11.1$ feet. At 950 feet it reached 43 per cent and at the lowest depth it was 41.05 per cent. From 640 foet downward the rock was essentially dolomite, although it contained an excess of calcite. Pure dolomite contains 45.65 per cent of magnesium carbonate, a figure that was very nearly approached.

The column of rock represented by the Funafuti boring thus appears to be divisible into three fairly definite zones. The surface layer is about 25 feet thick, and its composition is directly determined by the organisms living above it. In this zone the evidence of concentration by leaching is quite clear. From 25 feet down to 6.10 feet the rock is essentially a limestone, with very little magnesia. The lowest zone, from 640 feet downward, is dolomite, and the dividing line between this and the limestone above is very distinct. Within 3 feet the proportion of magnesium carbonate in the rock rises from 2.44 to 26.33 per cent.

'To account for all the differences in the Funafuti column does not fall within the scope of this investigation, even if it were possible to explain them. Possibly the limestone of the middle zone was laid down during a period when nonmagnesian organisms were relatively much more abundant than they are now. 'This supposition, however, does not account for the sudden change from limestone to dolomite in passing from the second to the lowest zone.

In order to partly explain these changes we venture to offer some purely speculative suggestions, believing that speculation is legitimate if it tends to stimulate investigation or to provoke a closer scrutiny of existing evidence.

The lowest portion of the Funafuti rock is, of course, the oldest, and it contains fragments of Lithothamnion and other organisms which flourish abundantly only at moderate depths. Magnesia was then concentrated in the rock, in part directly from living forms and in part by leaching, as at present. 'The thickness of the rock shows that it must have been deposited during a long period of depression, which may have submerged the island to a depth at which few of the magnesian organisms, especially the alga, could thrive. A prolonged rest, a period of equilibrium, then followed, during which very little rock was formed, and in this period much of the dolomitization took place.

The period of rest was succeeded by one of elevation, which brought the dolomitic rock again to the surface, when reef building began anew, but with relatively fewer magnesian organisms than formerly. Between 552 and 660 feet the nommagnesian Malimeda is the main constituent of the cores. The new rock, then, was less magnesian than the older, and the sharp break between the two zones becomes intelligible. Magnesian organisms were not extinct, for their remains appear throughout the Funafuti cores, but they were much less abundant than at first. Whether this supposition is true or not might be determined by a quantitative study of the thin sections of the rock, which ought to be still in existence. The published records of them seem to be purely qualitative, except in so far as they indicate the frequency of occurrence of the different organisms. They do not show their relative quantities. ${ }^{70}$ At present magnesian organisms predominate, and their eomposition is reflected in the composition of the surface limestone.

Our assumptions regarding changes of sea level at Funafuti are not altogether imaginary. In their report upon the geology of the island T. IV. E. David and G. Sweet ${ }^{71}$ assert that

the surface geological evidence collected by us proves, in our opinion, that several oscillating vertical movements of the above have taken place in the immediate past at Funafuti, and we should not, therefore, be surprised if the evidence gained from the core shows that movements of the shore line in both directions have occurred at Funafuti at earlier epochs.

'The chemical and algal evidence reinforce the physiographic evidence. On the formation of "coral reefs" during subsidence or elevation there is an abundant literature, which we can not attempt to summarize. We are dealing with a specific instance from a single point of view. The subject is one over which there has been much controversy. Our principal assumption,

69 See the petrographic report by C. G. Cullis in The atoll of Fumafuti, pp, 39:-420,

70 The atoll of Fumaluti, tables on pp. 336-361.

"1 David, T. W. E., and Sweet, G., idem, p. 88. 
which may or may not be sustained, is that the dolomitic zone at Funafuti represents an old reef upon which the present reef is superimposed. A similar basing of new reefs upon older ones has already been pointed out by ' $\mathrm{T}$. Wayland Vaughan. ${ }^{72}$

On many other islands in the South Pacific dolomitized limestones which were originally reefs are found at elevations hundreds of feet above sea level. A number of these rocks have been described by E. W. Skeats, ${ }^{73}$ who made good series of chemical analyses of them and also discussed their origin. Organic and especially algal remains were common in the rocks and were clearly recognizable in spite of the fact that in many places they had been much altered by the process of dolomitization. In these islands an elevation of the land had clearly taken place. Similar limestones from the Fiji, Tonga, Tuamotu, and Ladrone islands have been studied by R. L. Sherlock, ${ }^{7 *}$ who found them to be composed in great part of algal and foraminiferal remains. Among 47 thin sections which he examined, "Lithothamnion" was found in 35 , Polytrema in 21, echinoderm fragments in 17, and corals in 15. In short, all the evidence goes to prove the importance of the algae as limestone builders and the subordinate character of the corals. This importance is now fully recognized by students of marine limestones and by paleontologists generally.

It is not our purpose to discuss the origin of dolomite in general, for probably the rock originates in more than one way. ${ }^{75}$ At Funafuti, however, and at other similar localities marine organisms have much to do with its origin, and that phase of the dolomite problem may appropriately be considered here. The first step in the process, concentration by leaching, has already been described, but that is only a beginning. The living organisms, plant or animal, contain much less magnesia than is required to form dolomite, and its quantity must be increased from some outer source. The source, or at least the only source which we can discover, is found in ocean water, in which magnesium is much more abundant than calcium. This source has been recognized by many authorities, and it is generally assumed that an exchange may occur between the magnesium of the water and the calcium of the limestones, the one replacing the other. This assumption is due to J. D. Dana, ${ }^{76}$ who sought to explain the dolomitization of a limestone on the island of Makatea.

That an enrichment in magnesia from sea water is possible is shown by some experiments made by C. Klement, ${ }^{77}$ who found that a concentrated solution of magnesium sulphate and sodium chloride, at $90^{\circ} \mathrm{C}$, attacked aragonite and corals strongly, yielding a mixture of carbonates containing as high as 41.9 per cent of magnesium carbonate. Calcite, on the other hand, was but slightly altered. In the light afforded by these experiments the nonmagnesian aragonitic organisms assume new importance and are perhaps more influential in the production of dolomite than the distinctly magnesian species. Their solubility is evident in the first stage of magnesian concentration; their alterability is effective in the second.

Klement's experiments, however, were performed with concentrated solutions and at a rather high temperature. Under natural conditions, with less concentration and at lower temperatures, the same reaction may take place very slowly but be equally complete in time. Fears, or even decades, may be needed to effect such changes as were produced in the laboratory within 48 hours. In the study of geochemical processes the time factor must always be taken into account.

So far, according to Klement, a mixture of the two carbonates has been formed. To convert them into the double carbonate, dolomite, another step must be taken, and here again time may be important. A porous rock has been produced, which is saturated with water and buried at a depth which subjects it to considerable pressure. If the two carbonates of calcium and magnesium were perfectly dry, pressure alone would probably not effect their union, but

${ }^{72}$ Vaughan, T. W., Papers from the Tortugas laboratory of the Carnegie Institution of Washington, vol. 5, p. 66, 1914.

${ }^{73}$ Skeats, E. W., Harvard Coll. Mius. Comp. Zoology Bull., Fol. 42, p. 51, 1903.

7 Sherlock, K. L., idem., vol. 39, p. 349, 1903.

75 For a rather full summary of the subject see Clarke, F. W., The data of geochemistry, fth ed., U. S. Geol. Surrey Bull. 695, pp. 557-572, 1920.

i6 Dana, J. J., Corals and coral islands, 3d.ed., p. 393, 1590.

77 Klement, C., Min. pet. Mitt., rol. 14, p. 526, 1394. See also Pfaf, F. W., Centralbl. Mineralogie, 1903, గ. 659, and Neues Jahrb., 13eilage 13and 9 , p. 485, 1894. 'Two separate papers. 
under the influence of moisture, with slight solution going on at the surfaces of the solid particles, there would be a degree of molecular mobility which might bring about combination. This is probable, although so fur as we know it has not been actually proved. 'The establishment of the fuets ought not to bo beyond the range of experimental investigation. Views similar to ours relative to the formation of dolomite have already been advanced by Général E. Jourdy, who especially recognizes the importance of the alga, of aragonite, and of time. Much remains to be done, however, before the problem of dolomitization can be completely solved.

On the subject of phosphate rock we have little to say. We have shown that several groups of organisms are rich in phosphates, but the extent of their contributions to the sediments is uncertain. At best they can at first form beds of only moderately phosphatic limestone, which may perhaps be concentrated by the leaching away of the excess of carbonates. Vertebrate skeletons are also phosphatic and may possibly be more important additions to the sediments than invertebrate remains. In some localities limestones have been phosphatized by percolations from beds of guano, ${ }^{79}$ but that process is not one which needs to be considered here. It has no relation to the present research.

In the course of our investigation we have made one very curious discovery, to which we have repeatedly called attention, namely, the fact that in certain groups of organisms the proportion of magnesium carbonate is dependent upon or determined by temperature. 'The crinoids and alcyonarians show this relation very clearly, and it is also suggested by our analyses of foraminifera, crustaceans, and algæ. As a rule the organisms from warm waters are much richer in magnesia than those from cold waters, and the observed differences are often strikingly conspicuous. 'This rule, or rather tendency, we are inclined to believe is general, although we must admit that there are probably exceptions to it. Whether the increase in magnesia in passing from cold to warm regions is absolutely regular or not we do not venture to say, but apparent irregularities may be due to any one of several different causes. Slight analytical errors, uncertainty as to exact temperatures, impurities in the specimens analyzed, and differences in the concentration of sea water may all help to produce irregularities, which, however, are not likely to be large. The salinity of ocean water is very variable; it is 3.5 per cent in the great ocean, 4 per cent on the southern shores of the Mediterranean, and less than 1 per cent in the Baltic, differences that are great enough to exert some influence upon the vital processes of marine animals. Although the ratio between calcium and magnesium is practically constant in all oceanic waters, a concentrated water would contain more magnesium, volume for volume, than a water that was more dilute. Whether an organism living in a concentrated water would assimilate more magnesia because of its enriched environment no one can say, but conceivably it might do so. The influence of temperature might in that way be slightly modified. This is only a suggestion, not a statement of established fact. That warmth favors the assimilation of magnesia by marine invertebrates seems to be reasonably certain, but why it should be so is not clear. The relation is definite but as yet unexplained. We hope it is not inexplicable.

Attempts will probably be made to use our data in studies of climatology, but are such attempts likely to be fruitful? The question is not easy to answer. At a first glance it would seem as if warm regions should be more favorable to the formation of magnesian limestones than cold regions, but the evidence is by no means conclusive. $\perp$ dense population of coldwater organisms might add more magnesia to the sediments than a sparse population of warmwater forms. The massiveness of the animals must also be considered. The alcyonarian Paragorgia arborea, as its specific name indicates, grows to treelike dimensions, but its skeleton contains only about 9 per cent of magnesium carbonate. Tropical alcyonarians are much richer individually in magnesia, but they are not so large. One Paragorgia would therefore count

78 Jourdy, E., Soc. géol. France Bull., 4th ser., vol. 14, p. 279, 1914.

79 Clarke, K. W., The data of geochemistry: U. S. Cieol. Survey Bull. 695, pp. 515-526, 19:0; gives a summary of our knowledge of phosphate rock. 
for more than many smaller alcyonarians in the formation of magnesian limestone. If, however, the warm-water organisms are as abundant as the cold-water forms, and if their aggregate mass is as great, then the tropical linestones of marine origin should be more richly magnesian than those from higher latitudes. The determination of the facts we must leare to zoologists.

In conclusion we must express our thanks to the officers of the United States National Museum and the United States Geological Survey, who have aided us by furnishing authentic material for our investigations. Messrs. Paul Bartsch, Austin H. Clark, William H. Dall, W. L. Schmitt, T. Wayland Vaughan, and Frank ipringer and Miss M. G. Rathbun have all been most generous with their services. Dr. Marshall A. Howe, of the New York Botanical Garden, has also been nost kind in supplying us with alga, and Prof. L. R. Cary has kindly furnished us with raluable unpublished analyses. Without the help of these friends our research would have been impossible.

Addendum. - Since the manuscript of this paper was prepared Prof. A. G. Mayor ${ }^{80}$ has published an important paper on Rose Atoll, near Samoa. The reef here consists chiefly of Lithothamnium remains, with very little coral. Analyses of the reef rock by $\mathbf{A}$. H. Phillips gave percentages of magnesium carbonate ranging from 14.36 to 19.47 .

80 Am. Philos. Soc. Proc, vol. 60, p. 62, 1921.

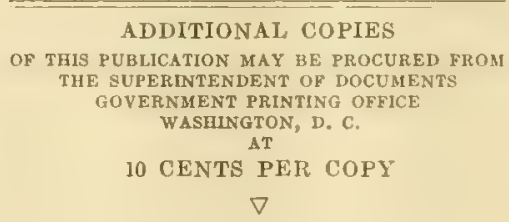








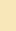





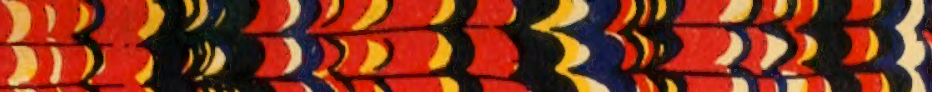

ग)

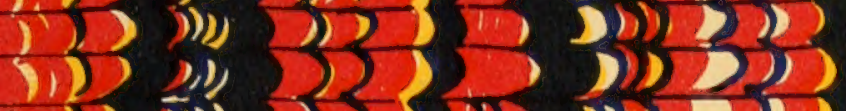

ग11) (ग)

i.) ग11. 2515

$\left(\frac{1, i)}{10}\right)$

02

ग) 3

(5) $3,1,23$

3232

$25, i, 1,325$

12

(ग) D)

b)

i)

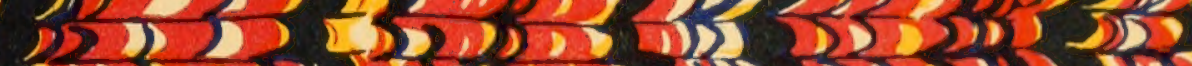

$2 \sum^{2}, 11,152$

D)

D)

3))

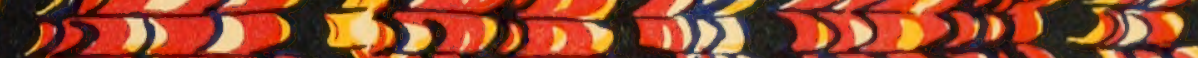

(3) (D) D) DID 2102 D) (11)

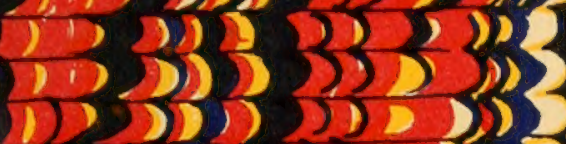
3 103 D) 12013 2035

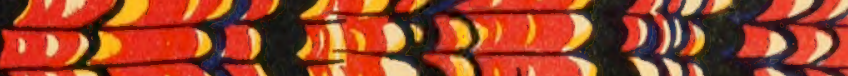

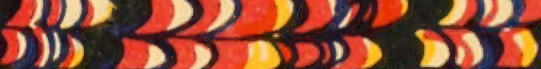

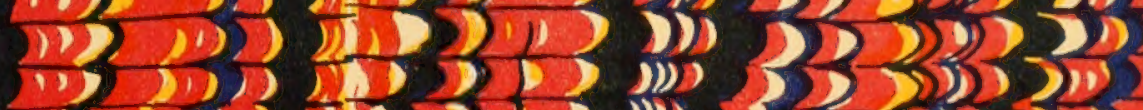

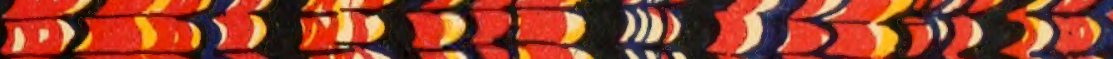
D) 1002012

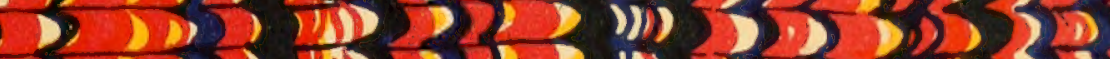

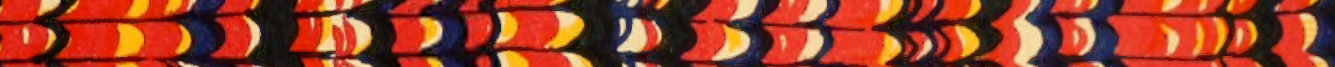
1) 12,152020

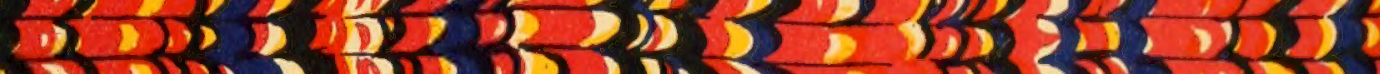

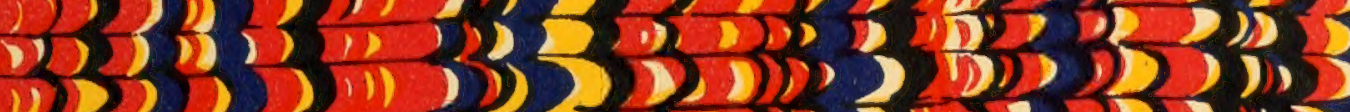

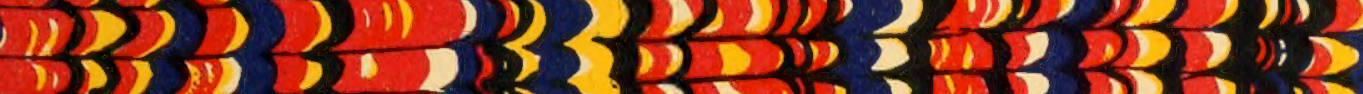

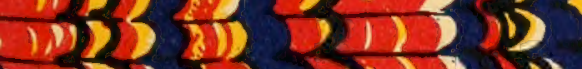

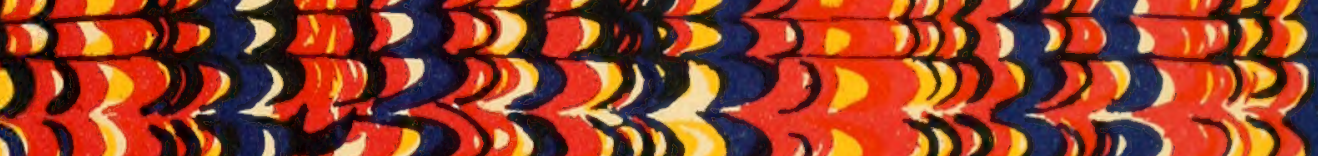
202122

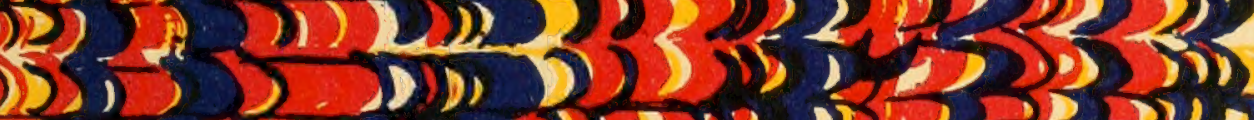
is 3 is 3 is 1250

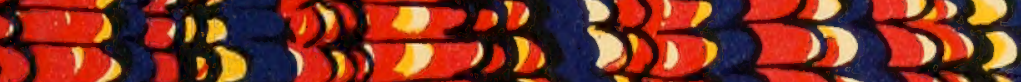

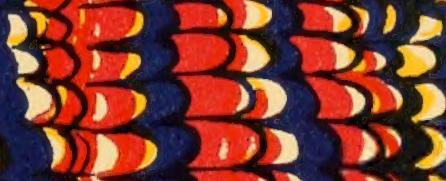

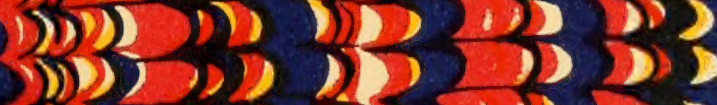

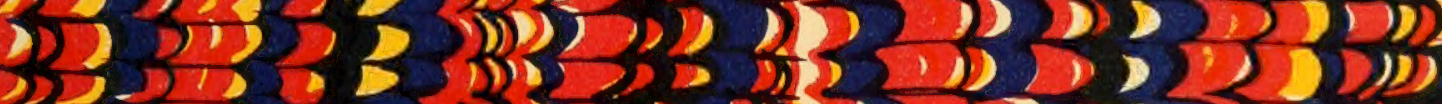
1) 132025 (D) D 2.13 D) D D 23,2 Di, DD

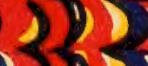

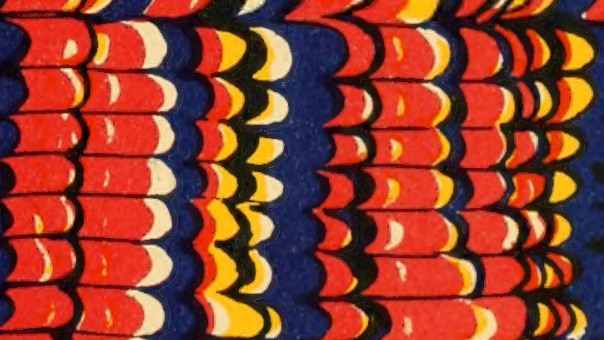

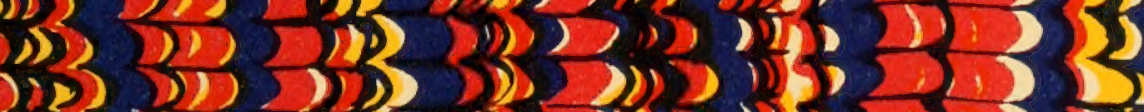
S) 5 in 250 ODD) 2 ) 3202 $-565$

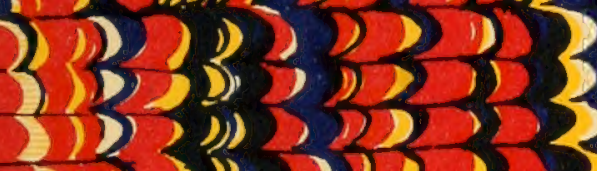

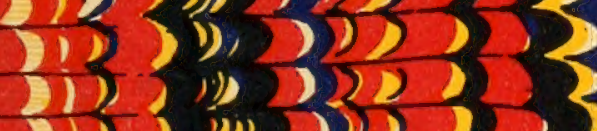
$302,125,1,1,2$

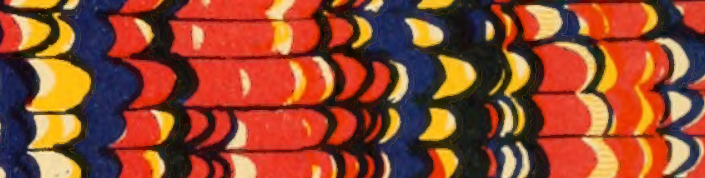

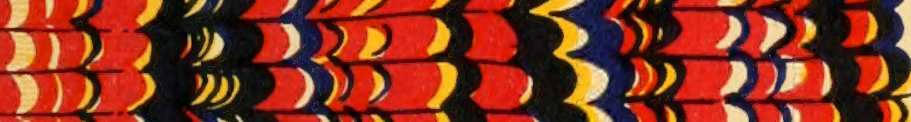
(5) 325,5 , 115 (3), $23,2,2$ (1)) 250 (0) 1 (1) $3 \pi(5), 53,1113$ ग) 23,2 3) 25 (11) $2 \frac{2 \pi)}{21)}$ 4 (2) 1205 (ग) D) 5 $0,10,11,20$ 32031, )) 218 )D D) 21 20) DiD Dis D) D) 32 $202032)$

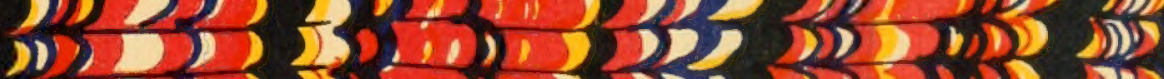
ग)

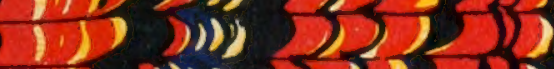
D) 52502 D) 20,513 22020 $\left.2 \sum^{2}, 11,1\right\}$ 02020200120

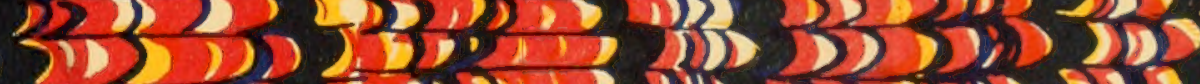
$(3,1,1,2$ (1) 125 $(1), 51,250$

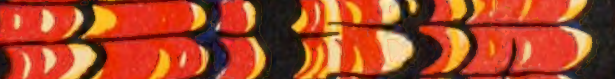

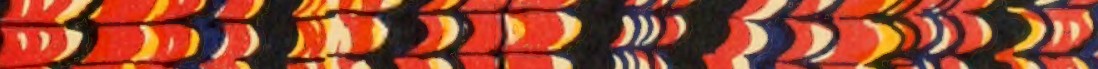

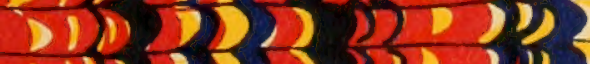

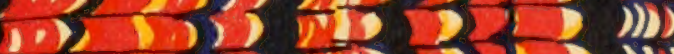
3i) $\triangle 2031250$ (1) (1) 10025 ())

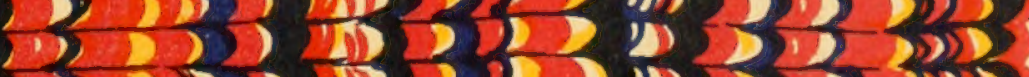

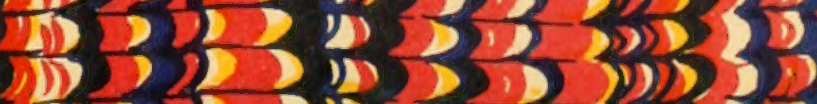

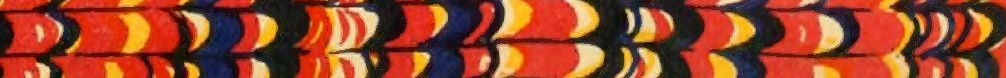




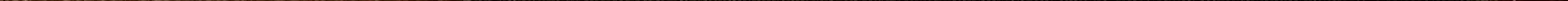

